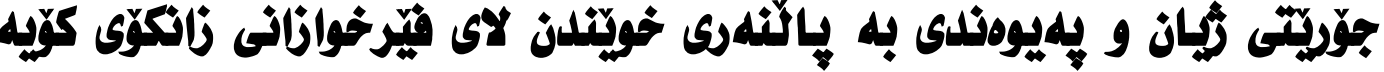

يايز خاليد سابير

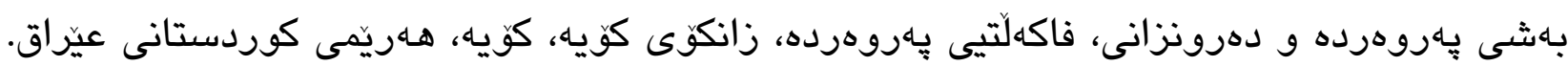

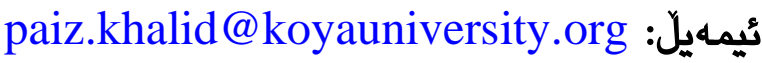

\section{خاليد ئيسماعيل مستهفا}

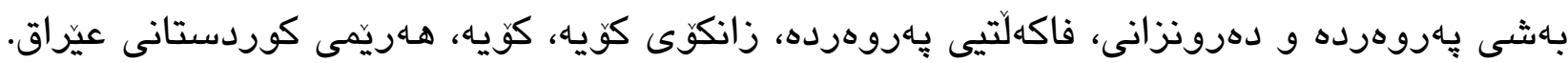
ئيمهيل: khalid.ismail@koyauniversity.org

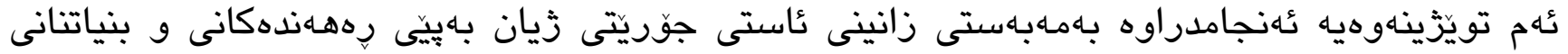

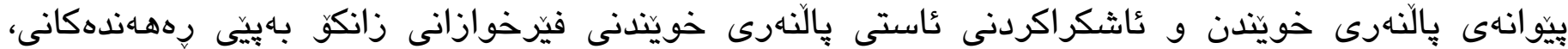

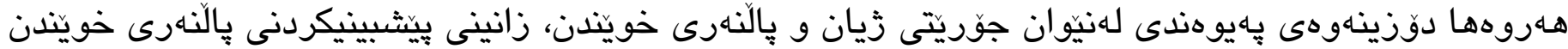

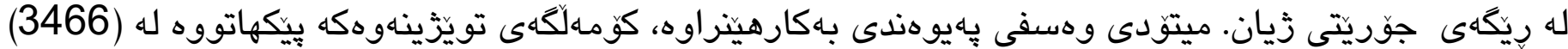

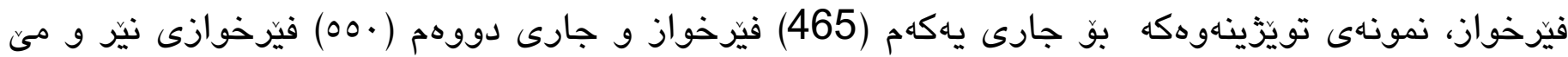

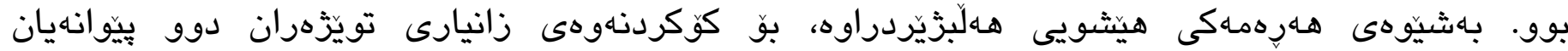

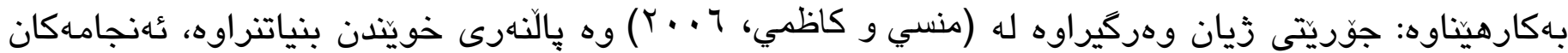

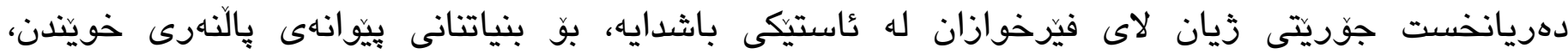

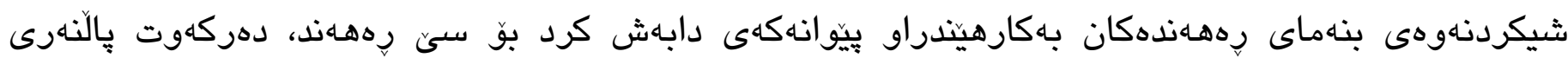

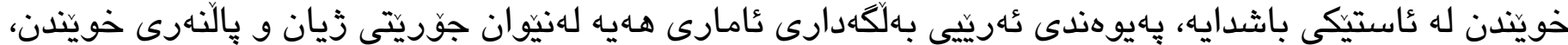

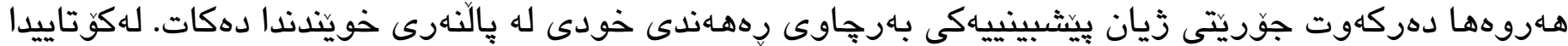

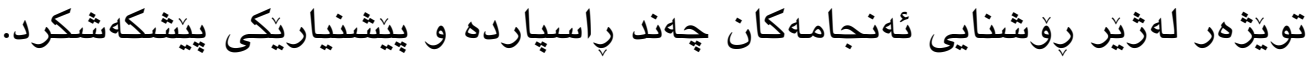

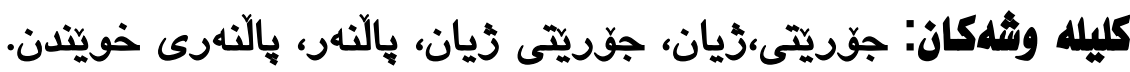




\section{ناساتلدى تويلزئنينهومكه:}

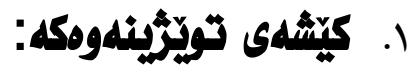

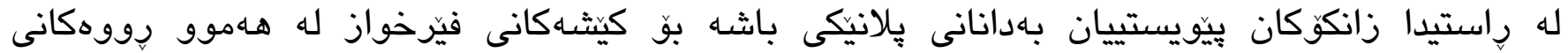

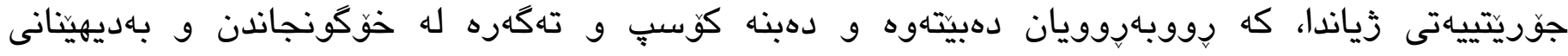

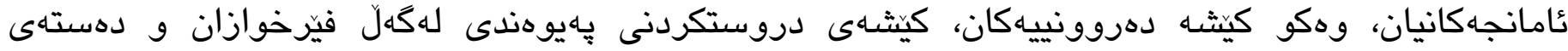

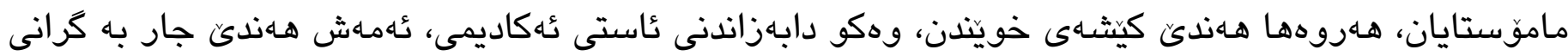

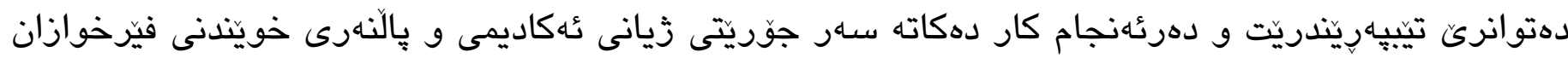

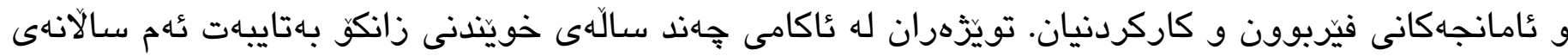

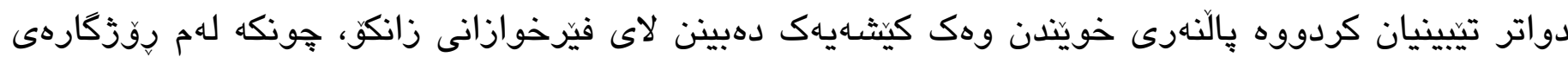

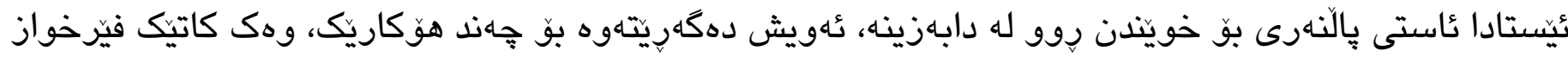

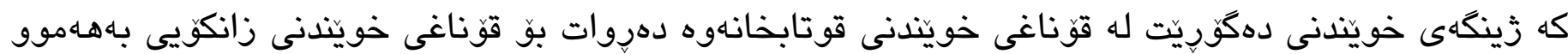

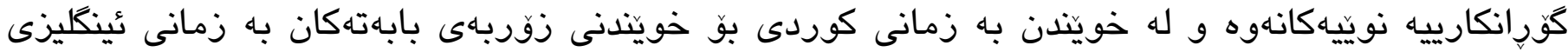

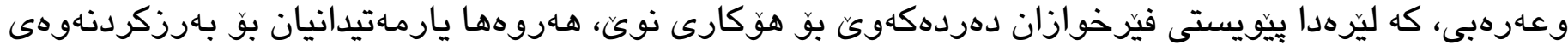

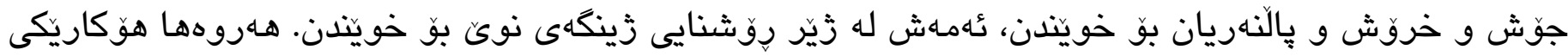

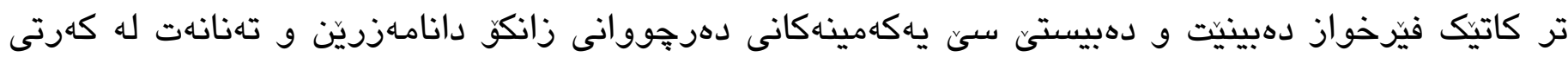

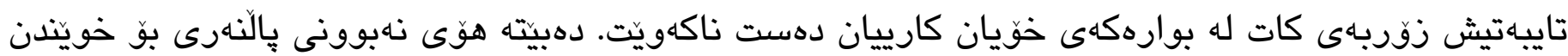

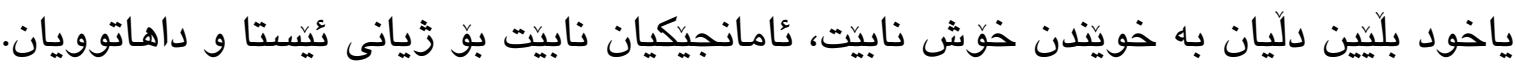

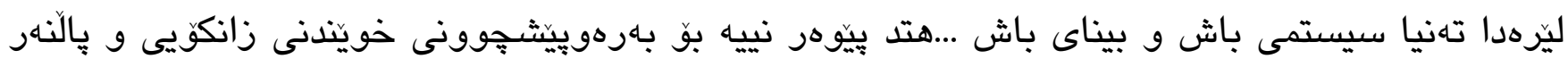

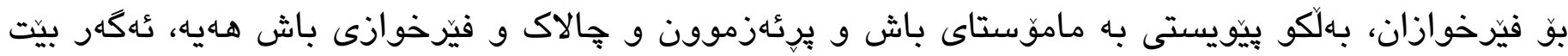

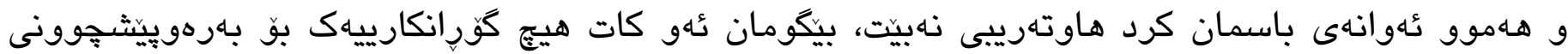

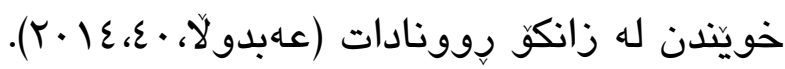

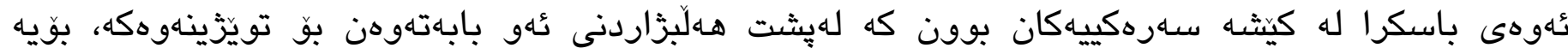

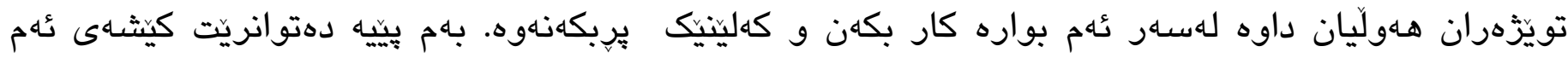

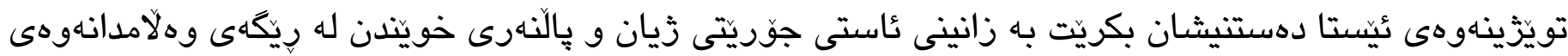

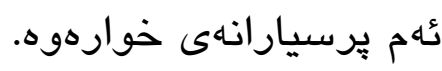

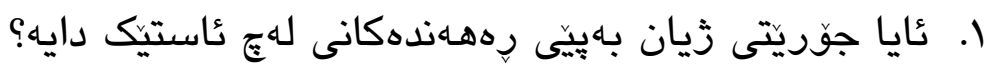

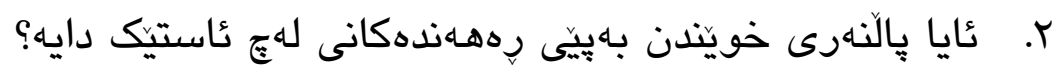

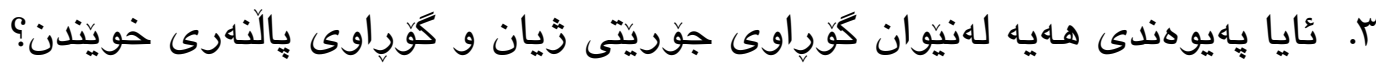

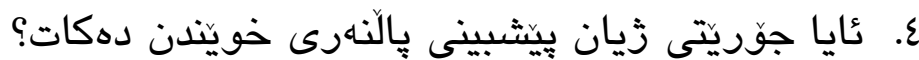

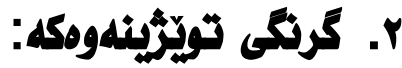

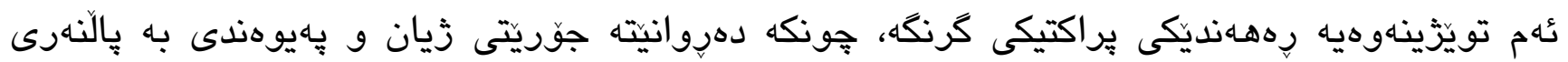

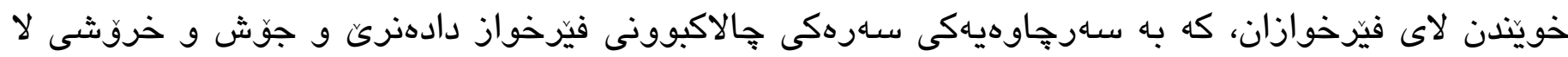

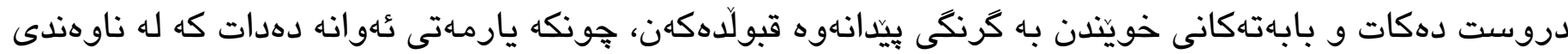

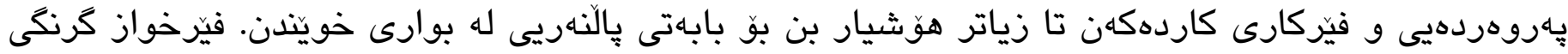




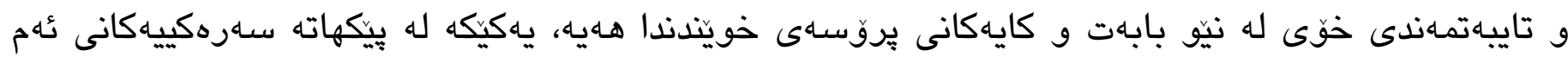

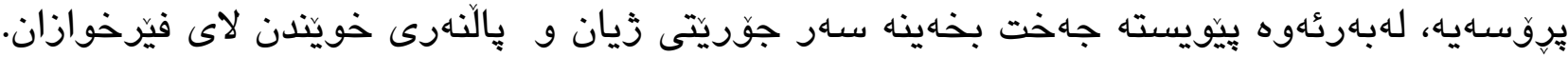

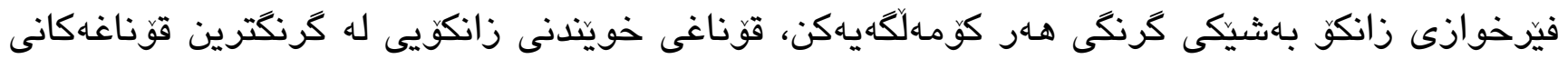

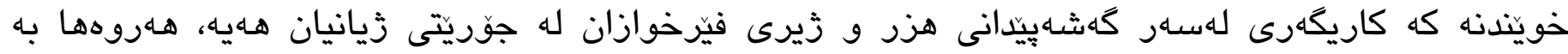

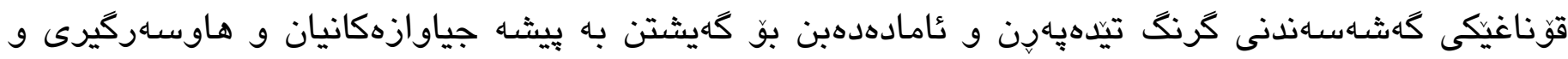

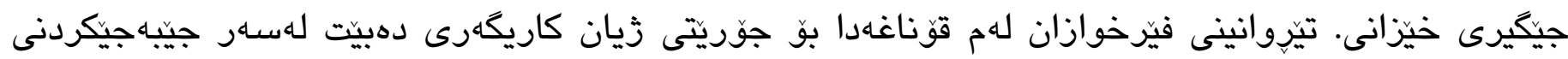

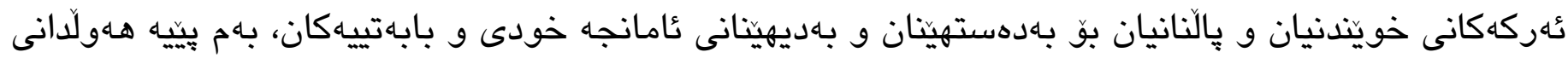

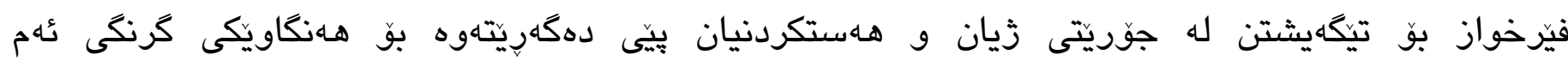

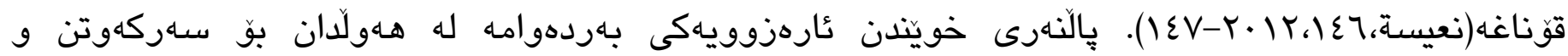

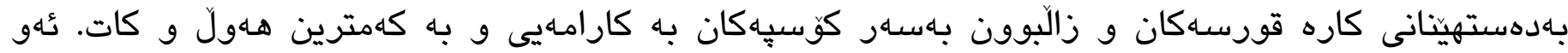

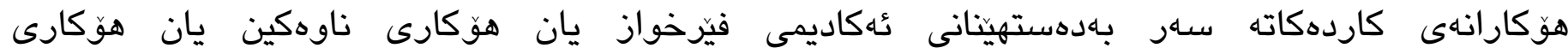

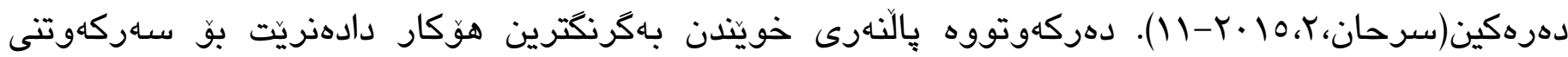

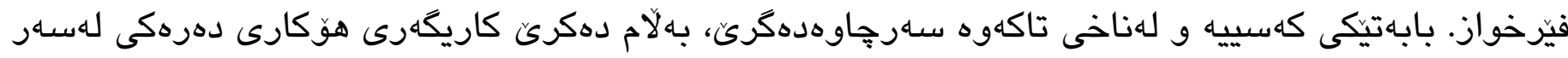

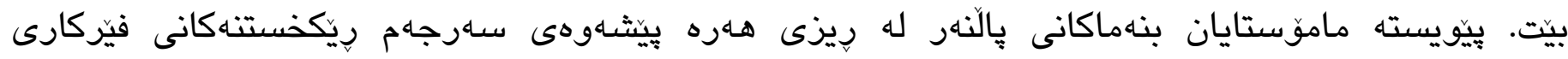

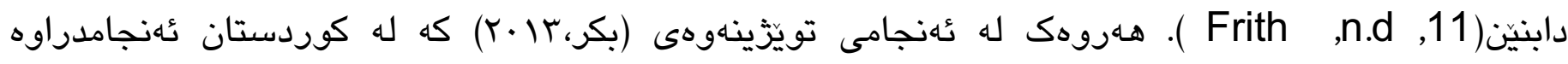

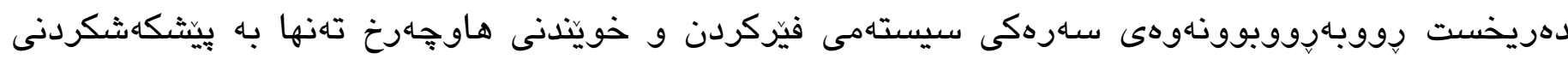

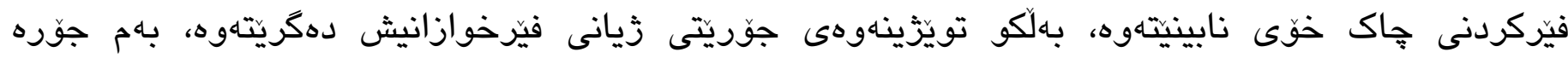

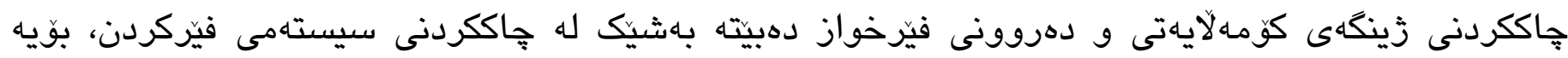

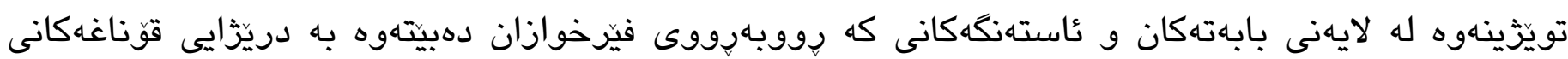

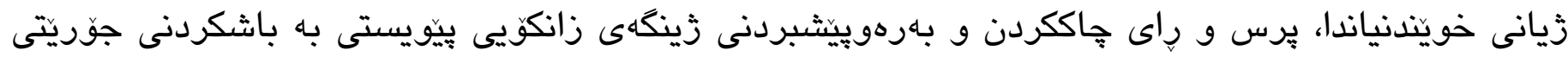

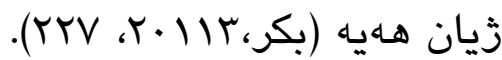

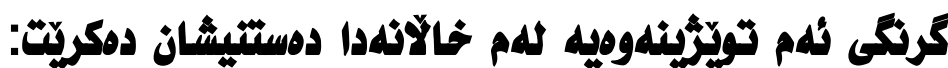

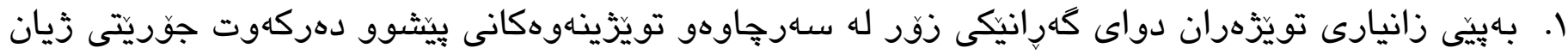

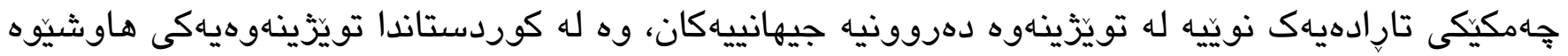

ئهنجامنهدراوه.

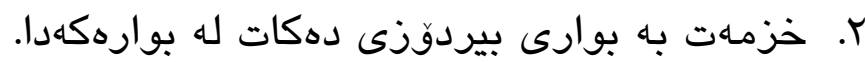

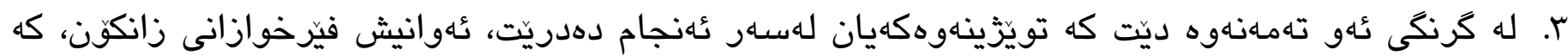

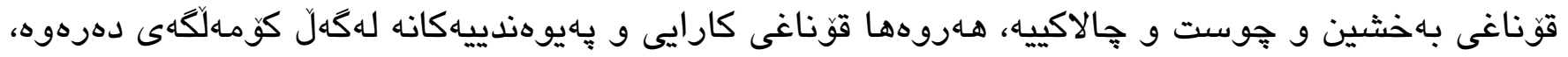

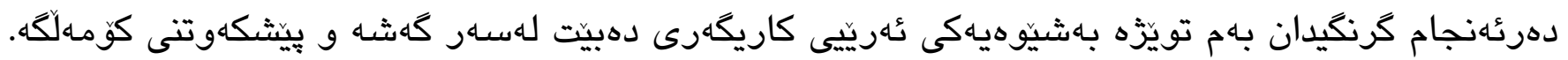

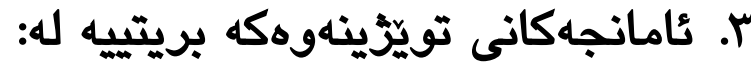

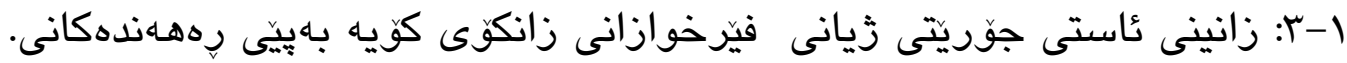

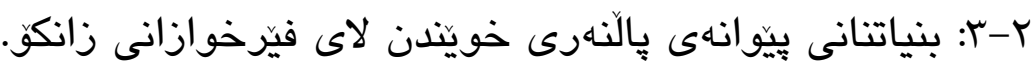

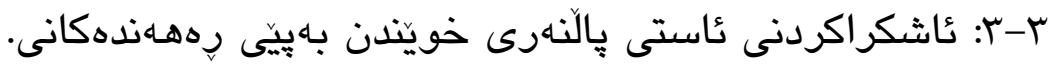

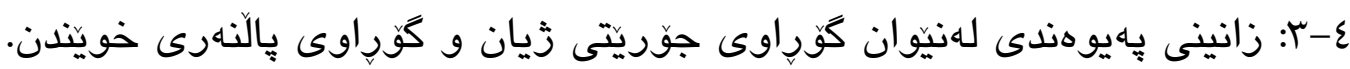




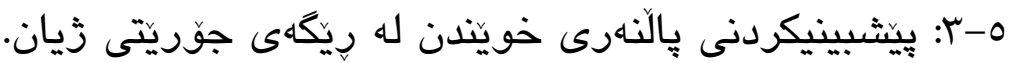

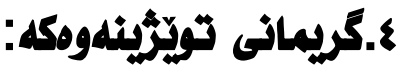

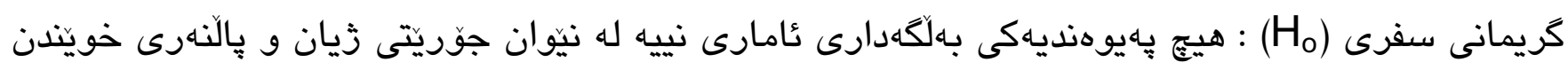

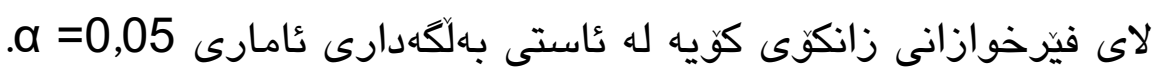

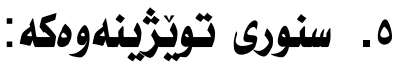

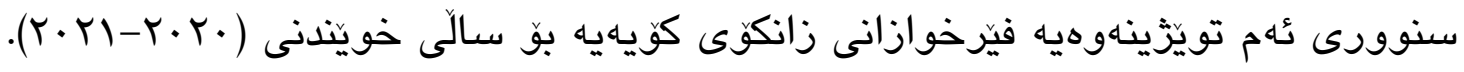

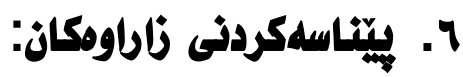

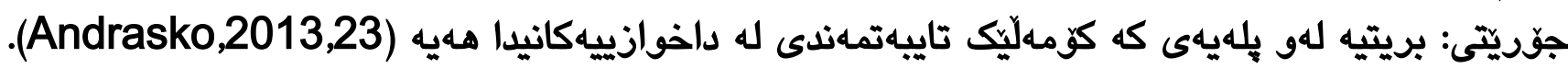

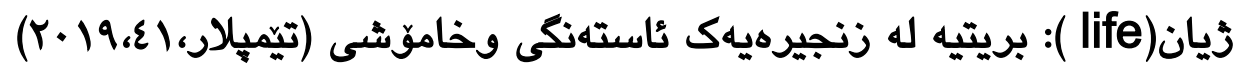

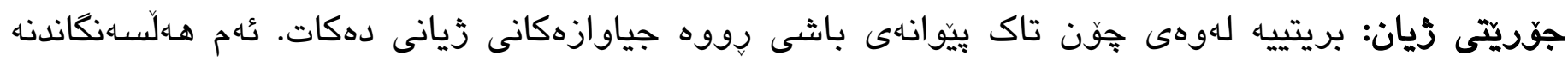

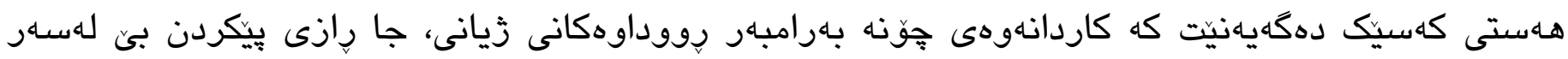

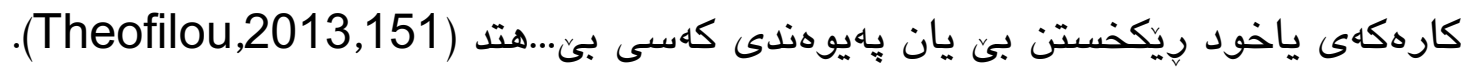

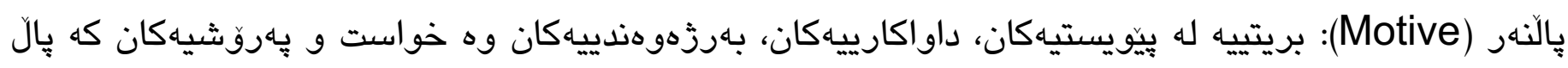

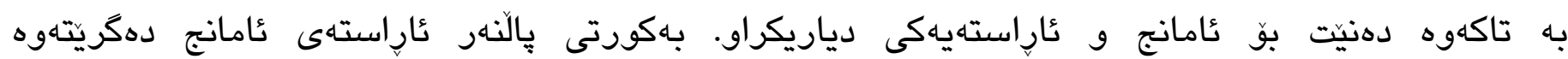
(Weiten,2007,376)

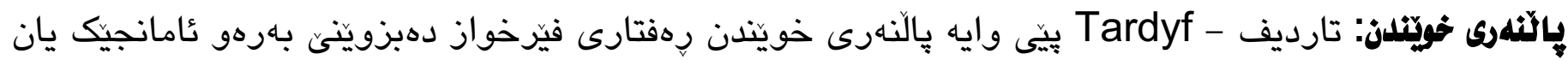

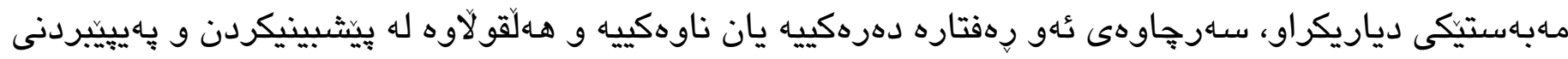

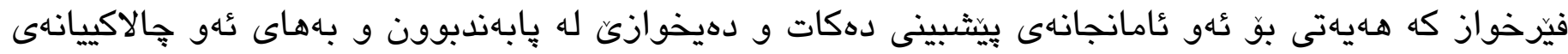

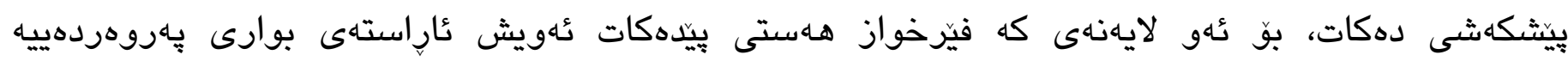

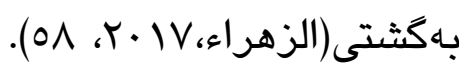

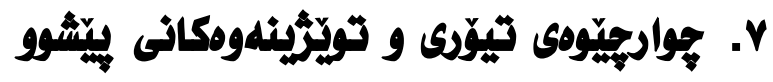

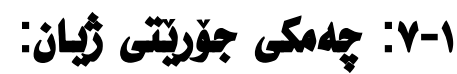

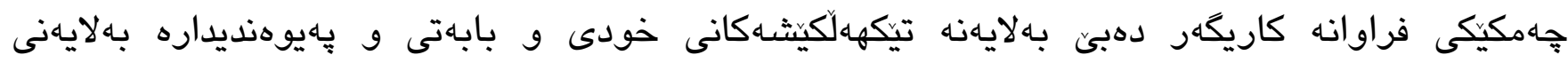

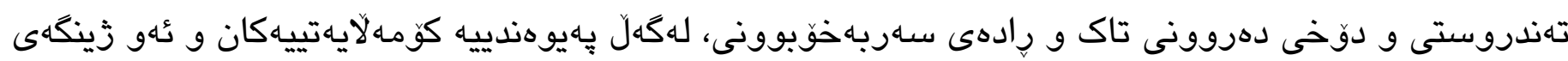

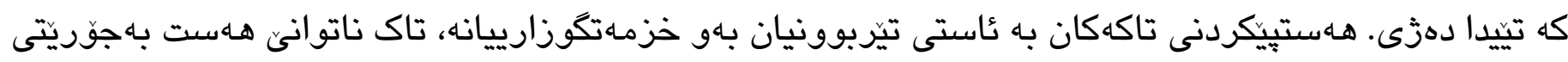

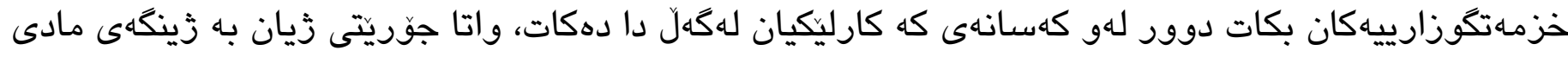

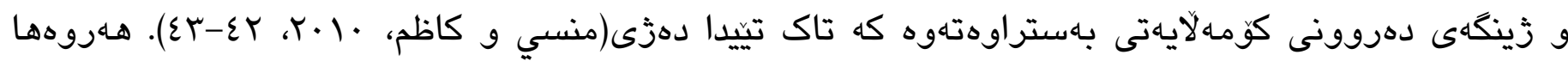

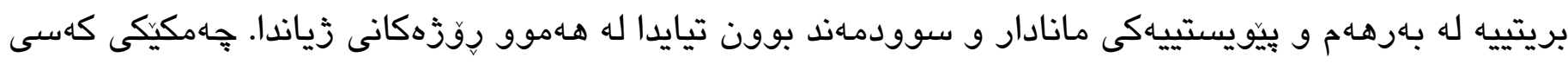

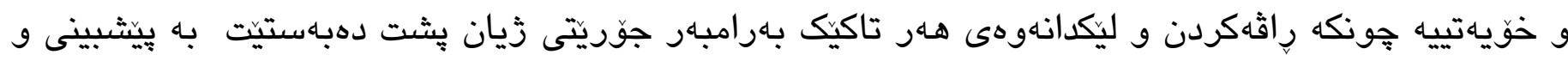

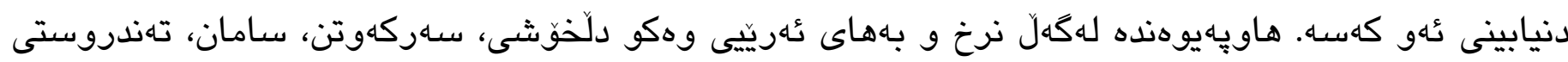
و رِازييوون(Mustafa, Ismail \& Abdullah, 2019,150). 


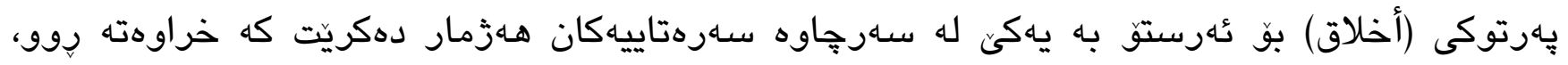

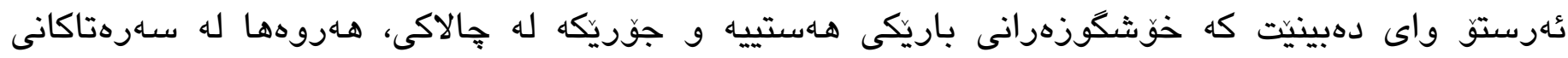

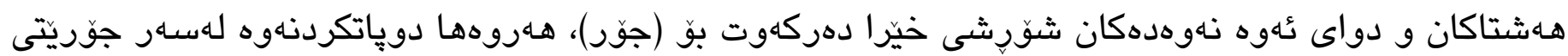

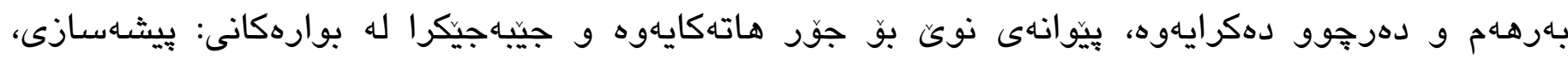

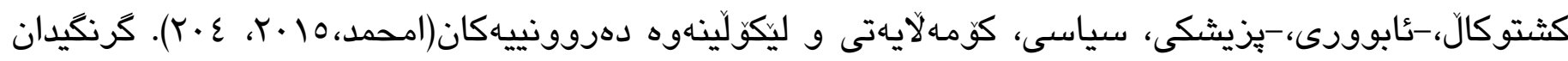

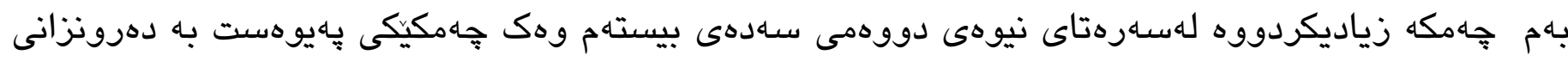

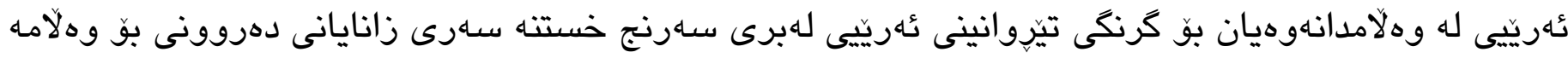

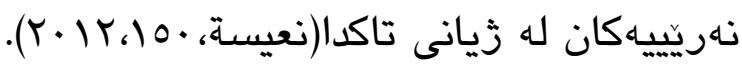

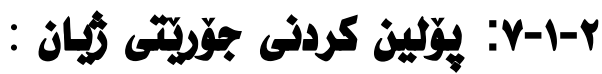

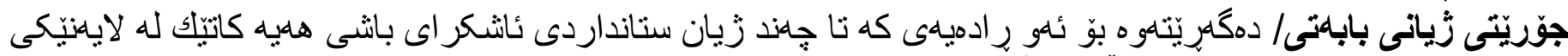

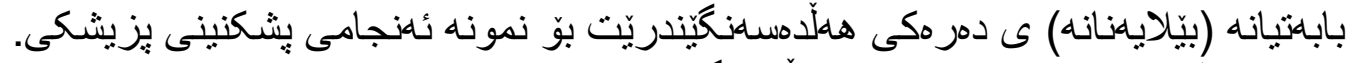

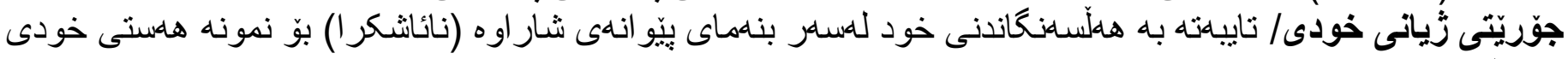

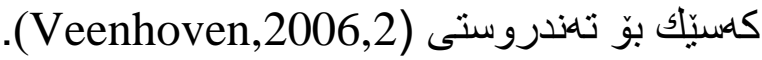

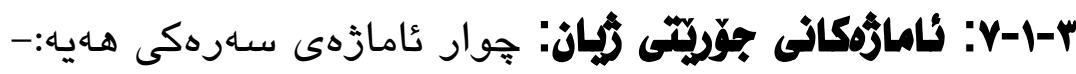

$$
\begin{aligned}
& \text { ا. د دروونييهكان . }
\end{aligned}
$$

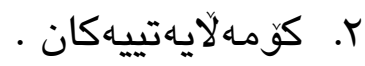

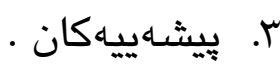

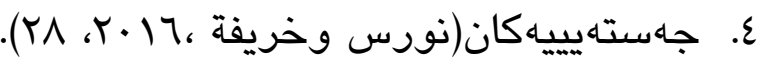

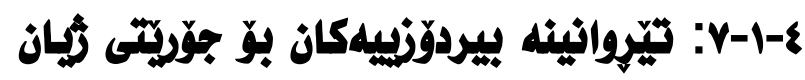

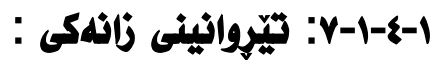

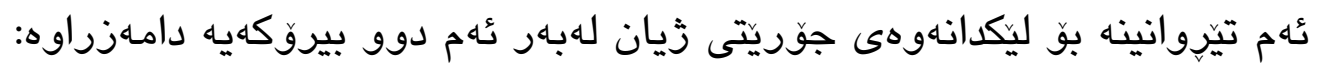

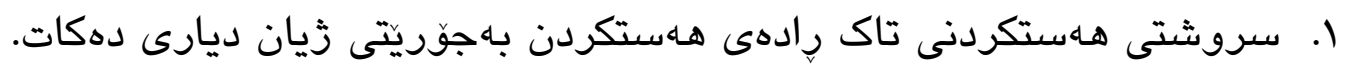

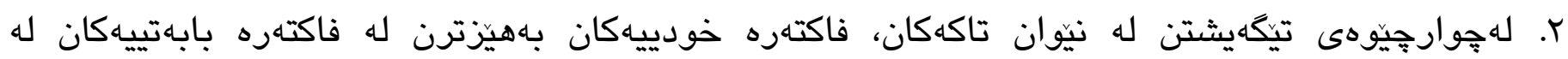

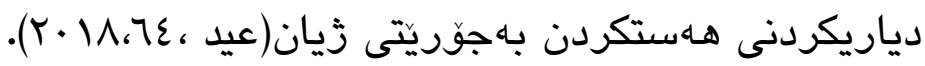

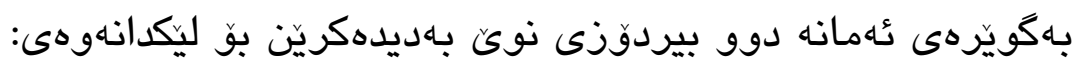

\section{يلهكلم: بيردوزى لاوتز (Lawton Theory (1997)}

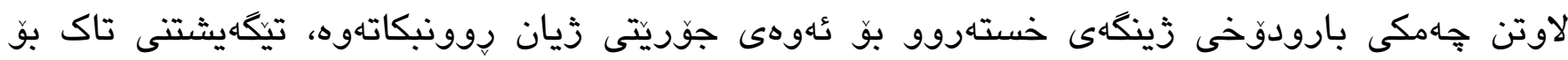

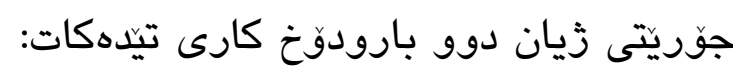

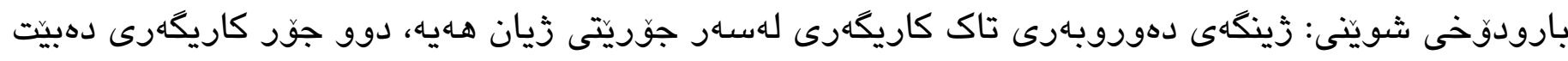

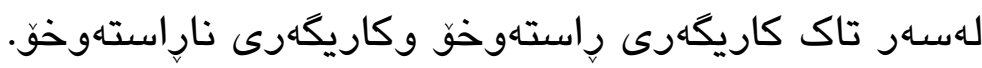




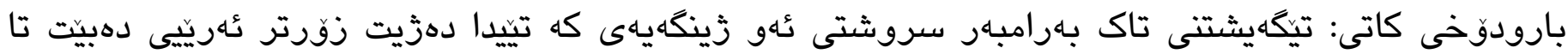

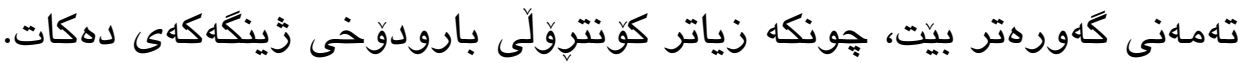

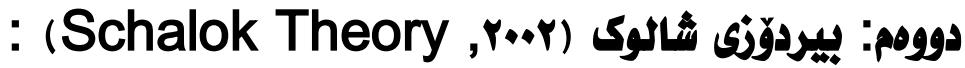

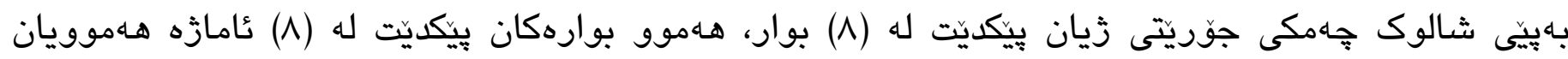

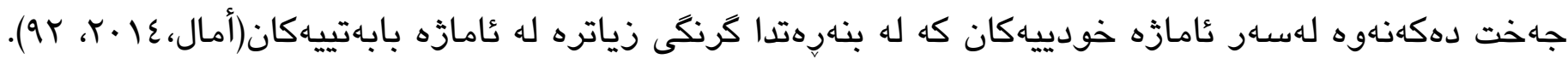

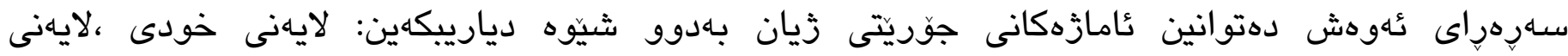

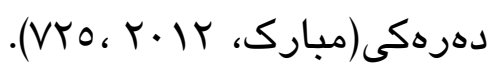

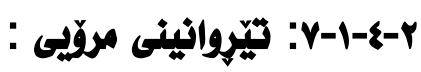

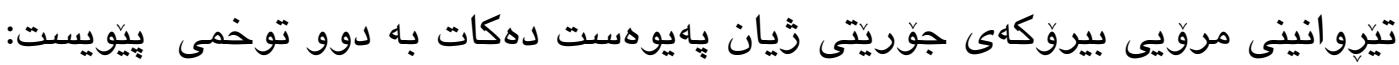

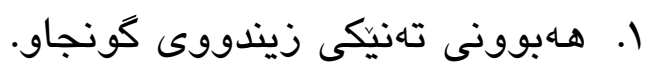

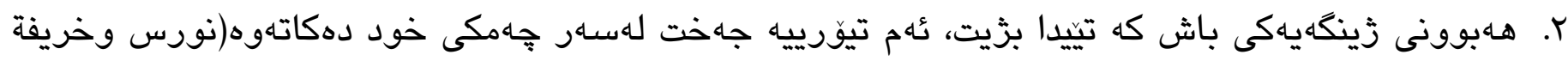
(T)

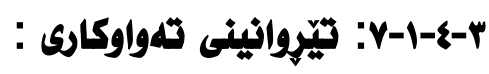

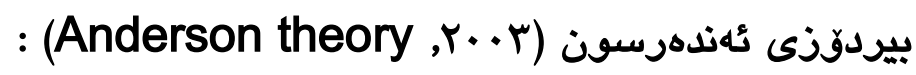

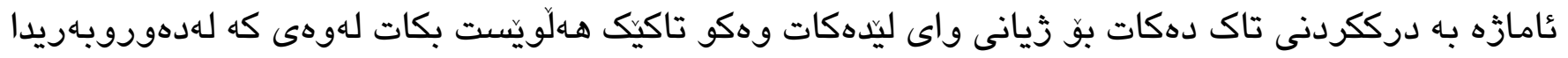

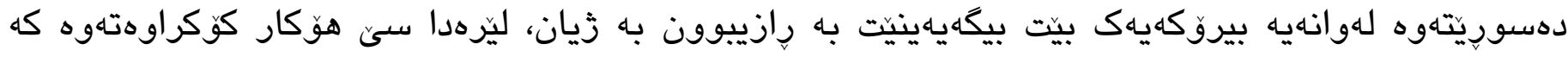

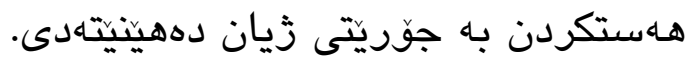

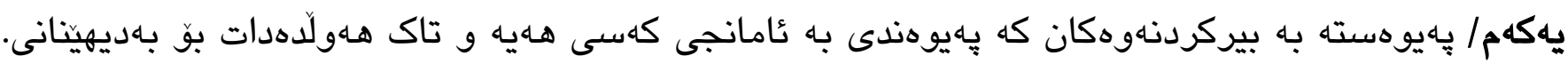
دووهم/ ماناى بوونيى (الوجودي) كه يهيوهندييهكان دابهشدهكات لهنيّوان بيركردنهوهكان و و تامانجهكان.

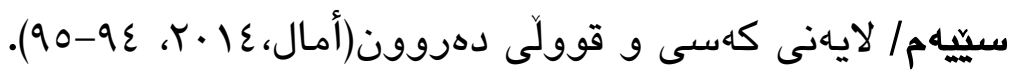

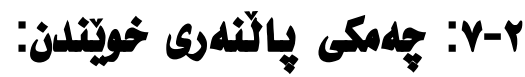

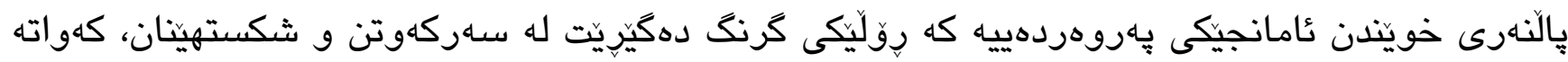

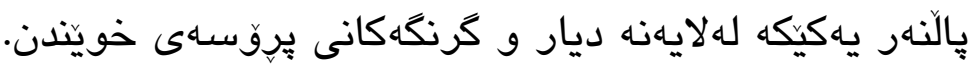

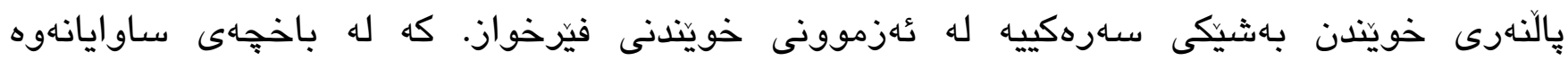

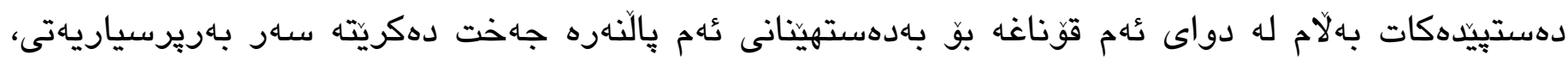

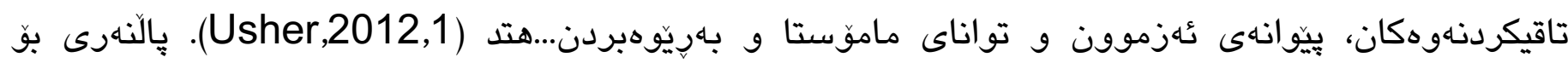

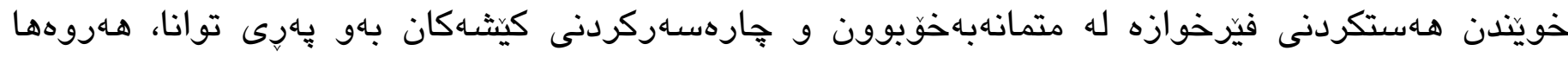

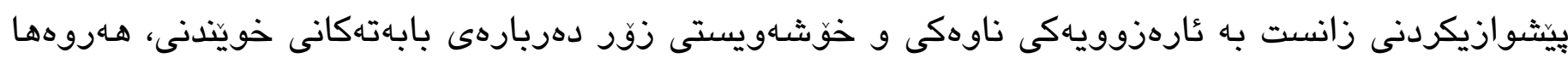

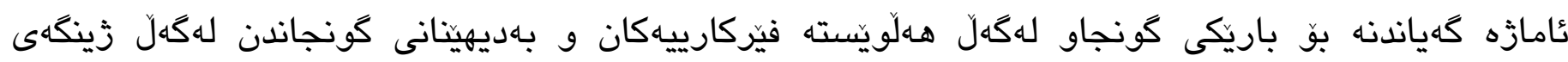

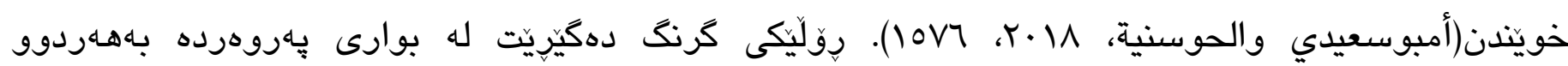

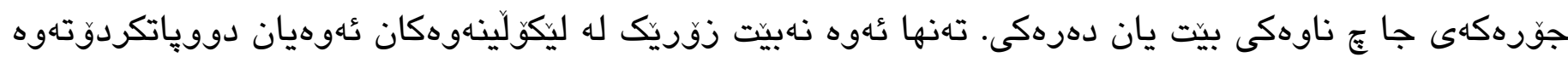

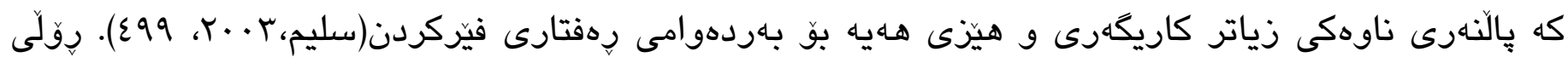

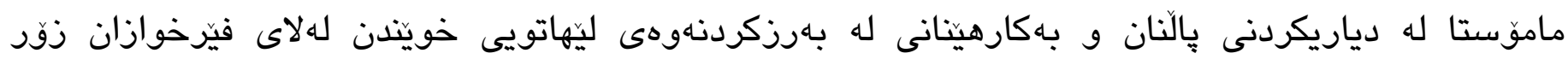




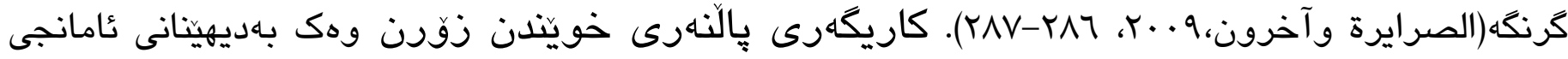

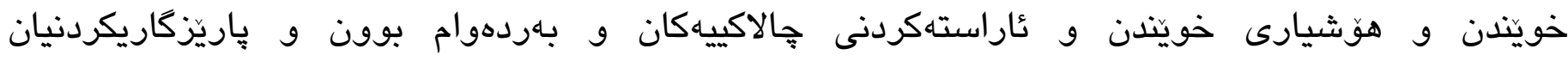

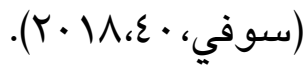

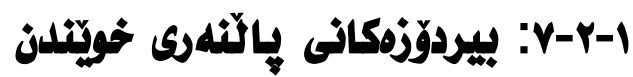

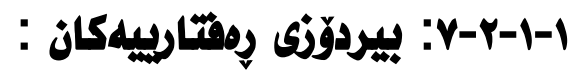

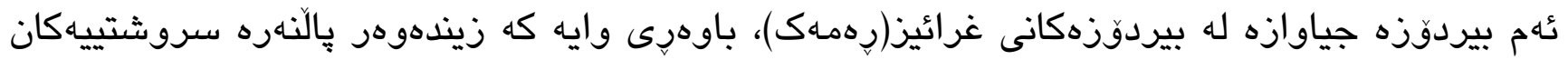

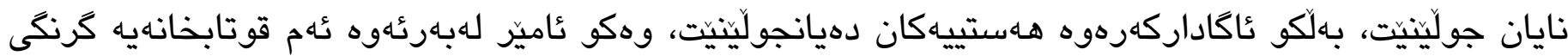

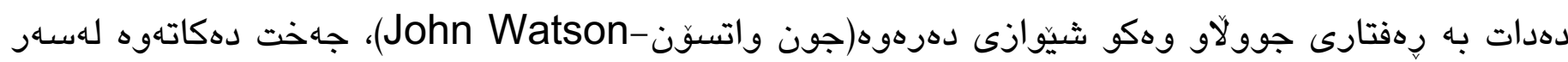

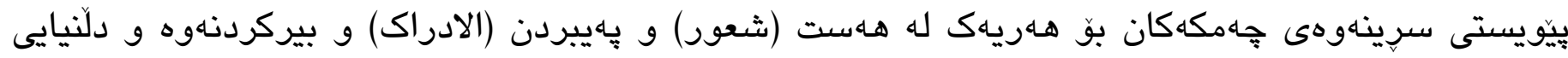

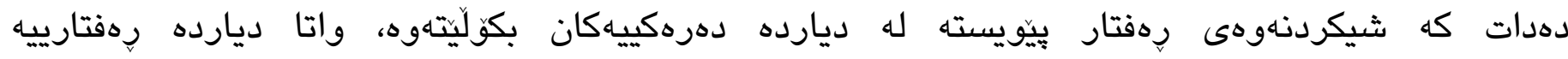

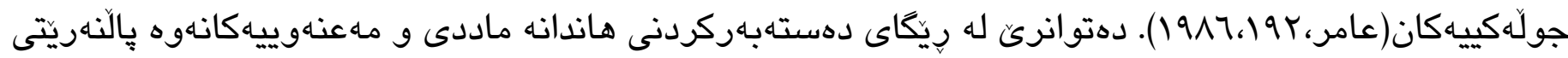

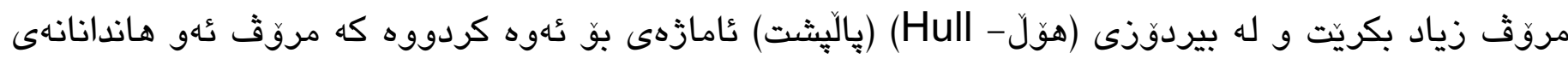

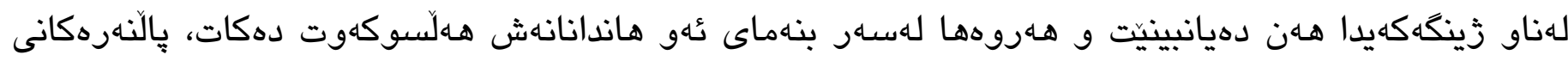

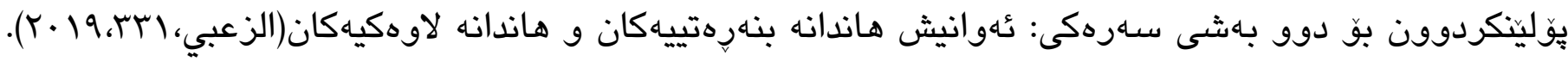

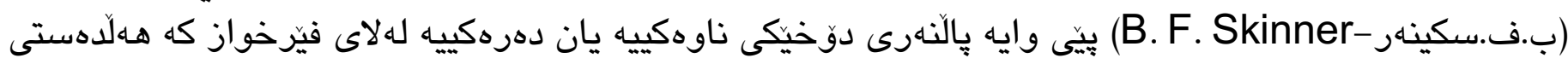

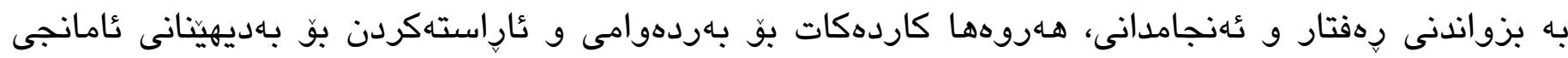

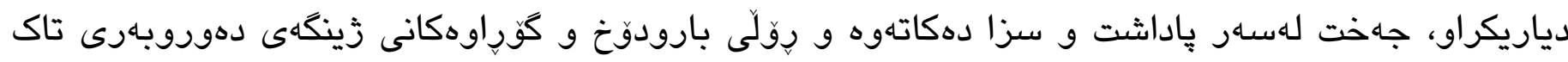

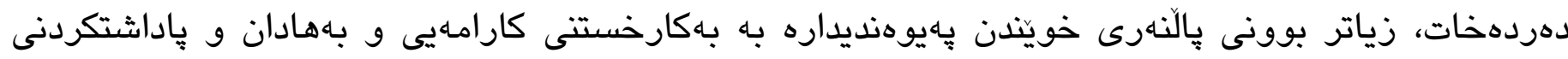

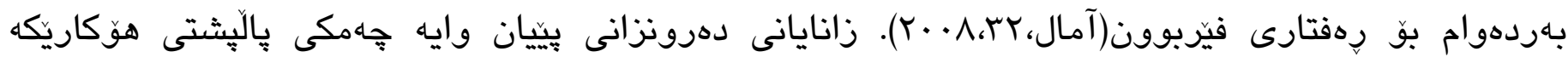

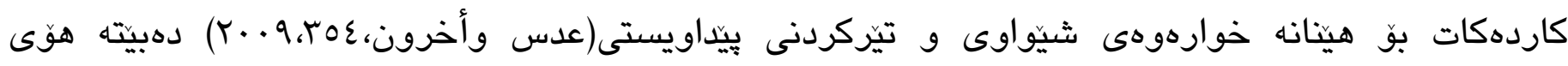

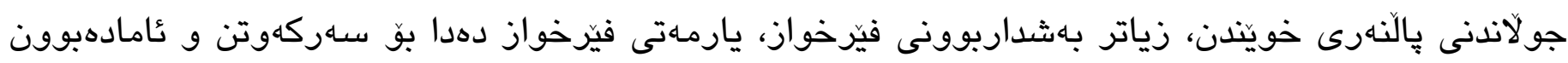

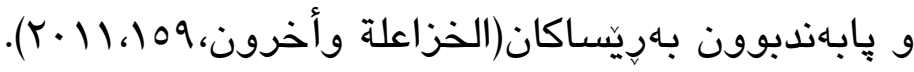

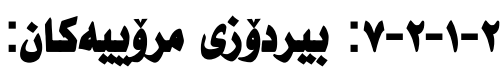

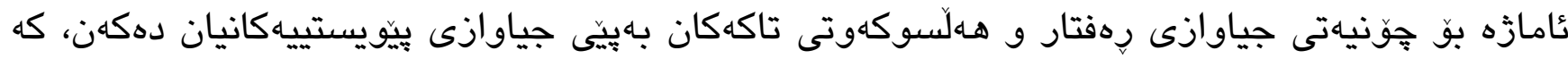

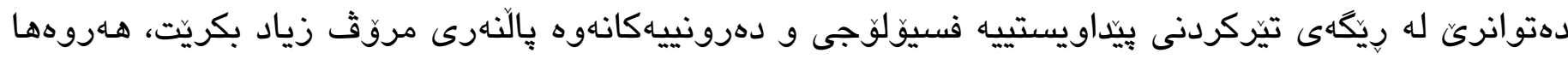

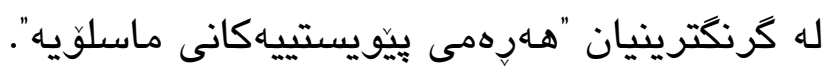

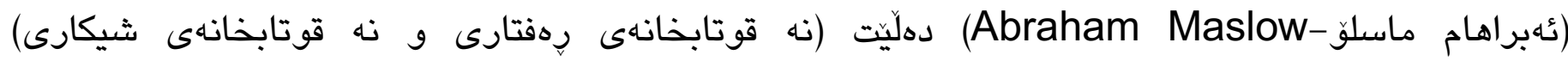

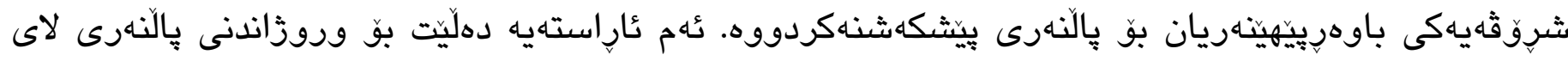

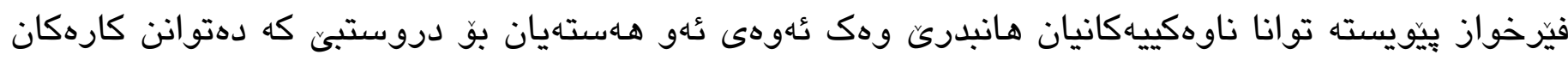

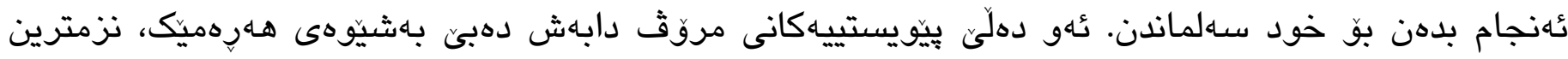

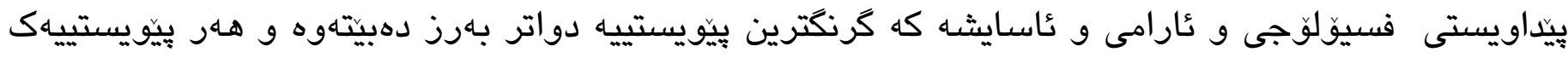

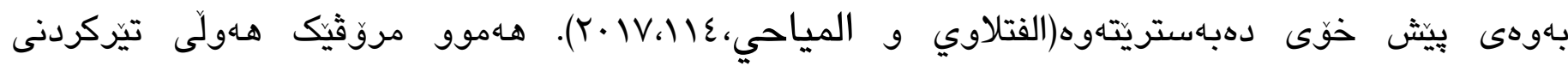

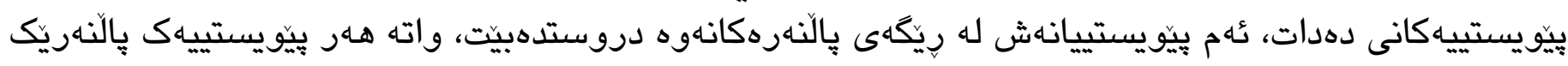

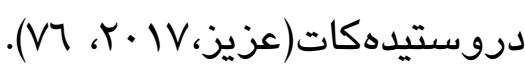




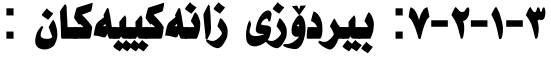

(جون ويليام أتكينسون- John William Atkinson) به ديارترينيان دادهنريتّ لهم بوارهدا زانهكييهكان

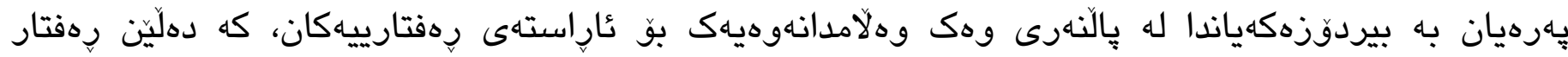

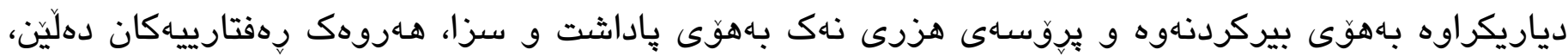

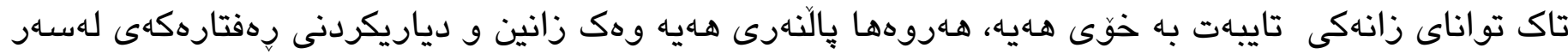

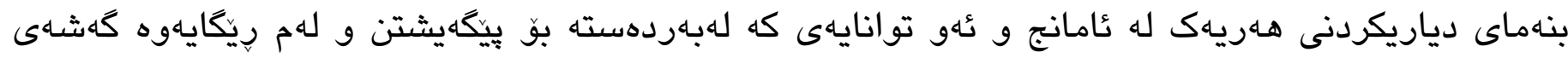

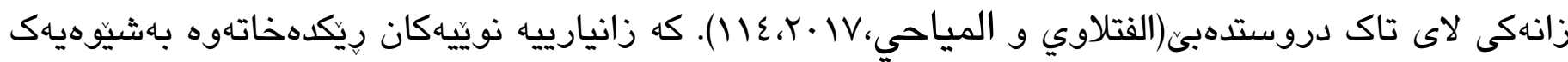

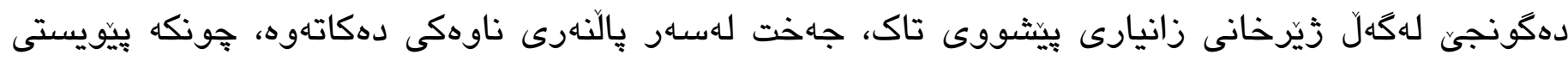

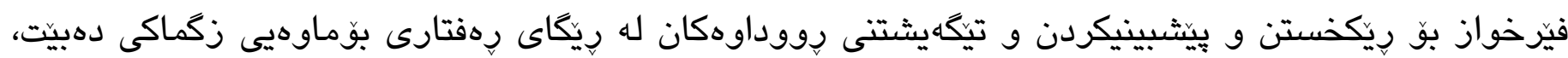

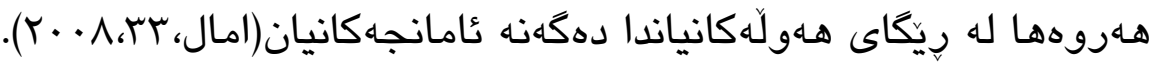

\section{ع-Y-Y}

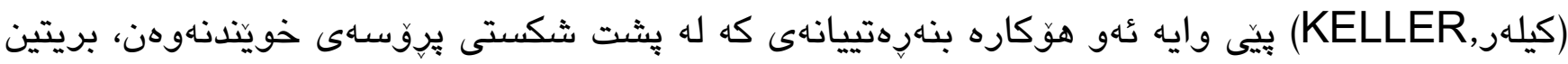

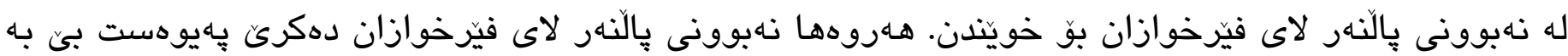

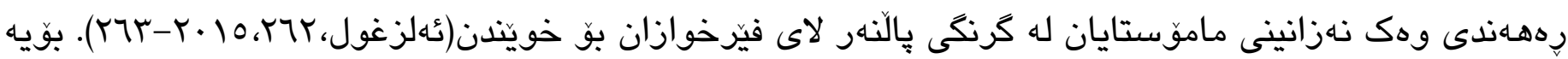

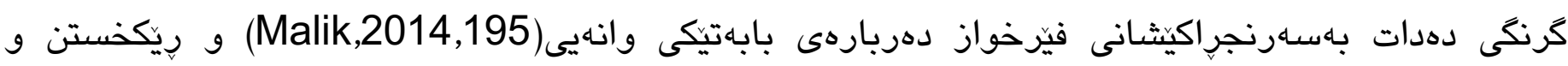

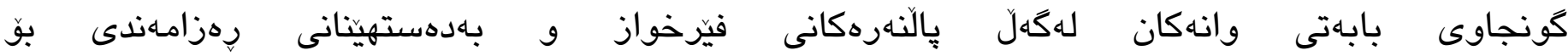

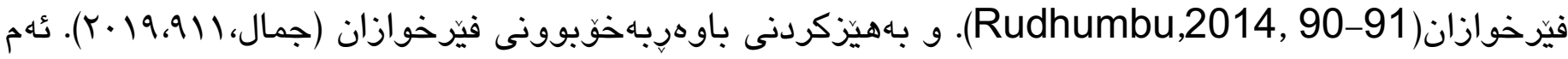

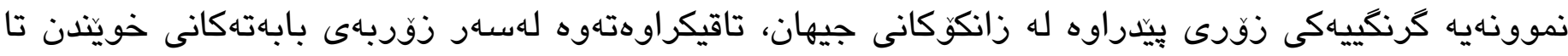

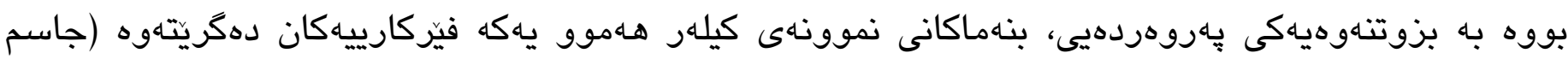

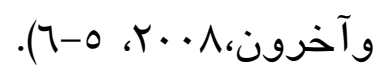

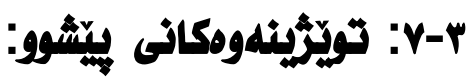

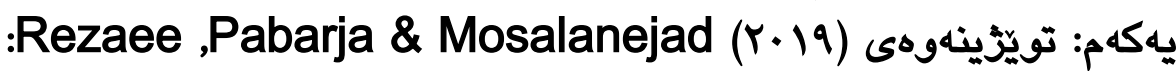

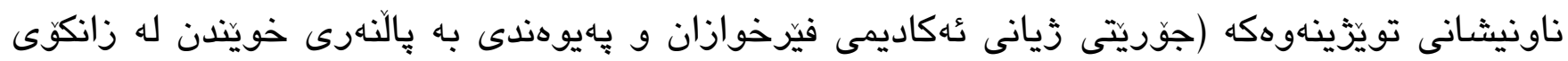

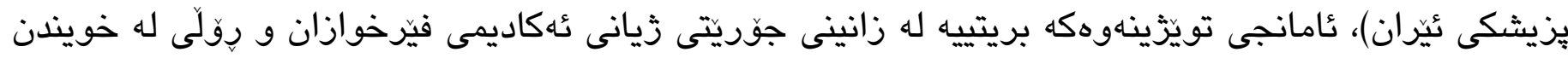

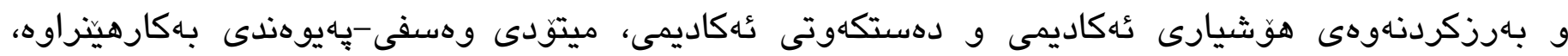

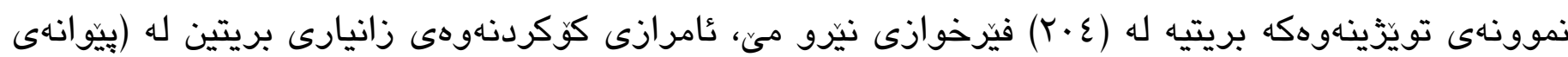

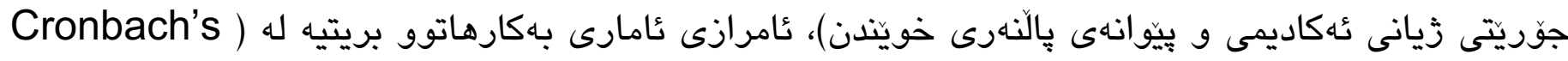
ئlpha

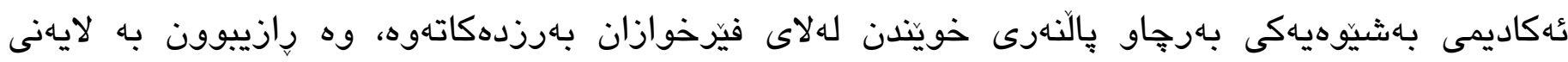

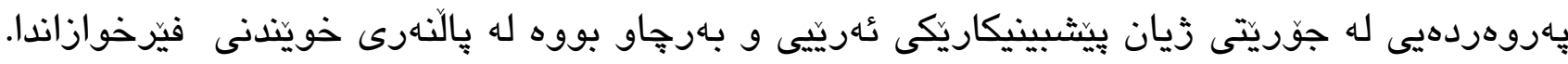

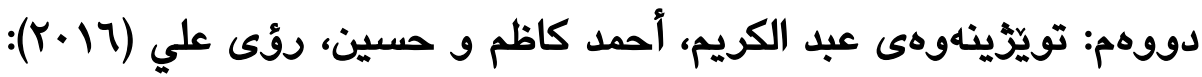

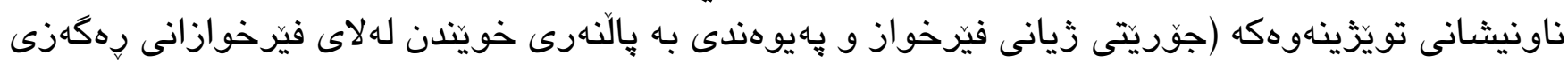

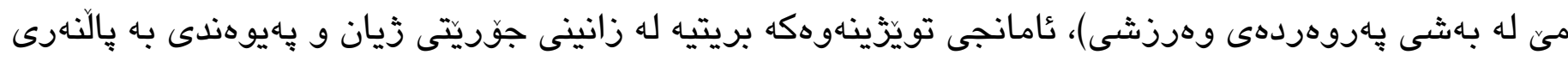




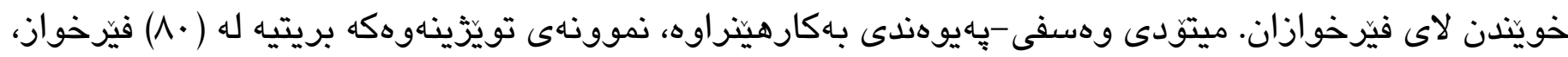

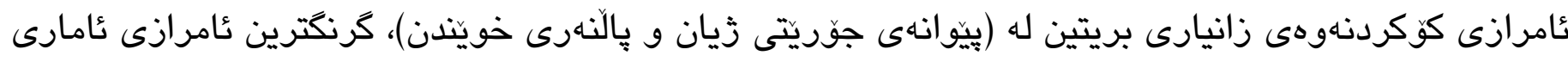

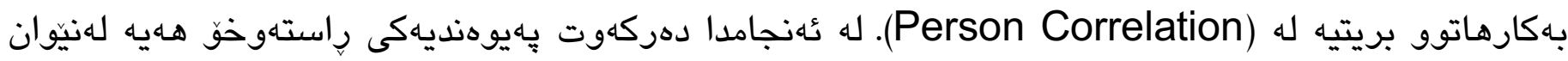

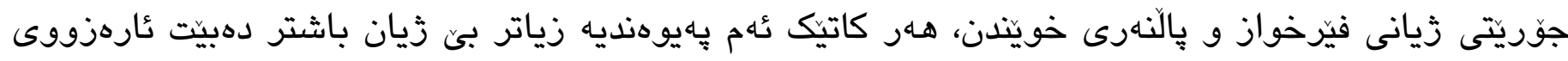

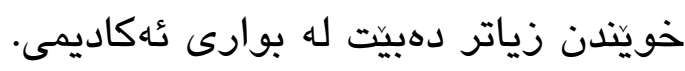

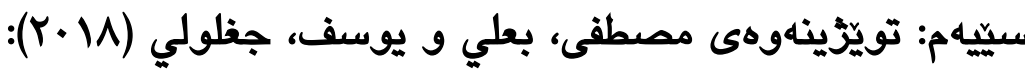

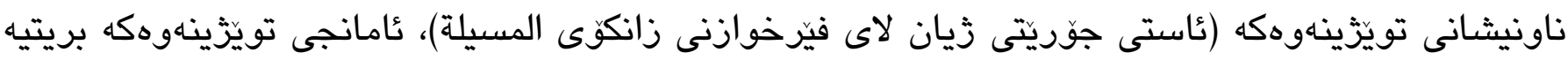

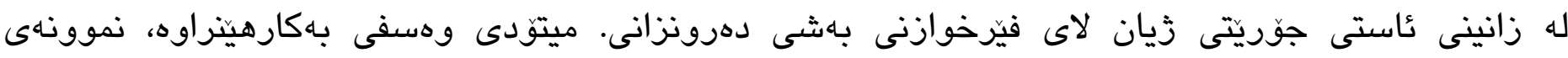

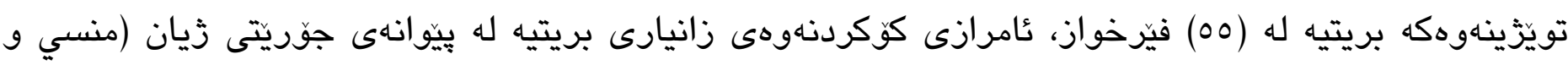

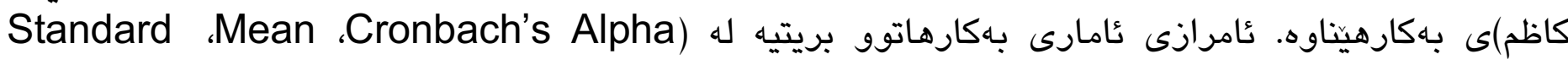

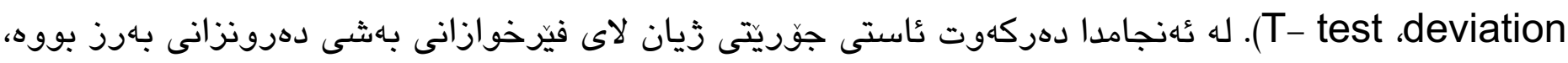

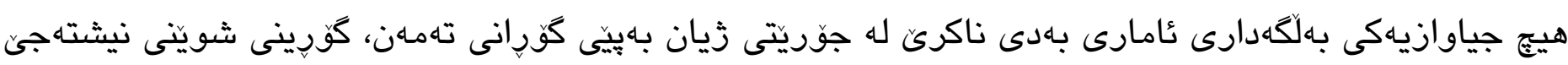

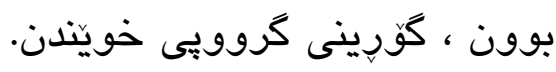

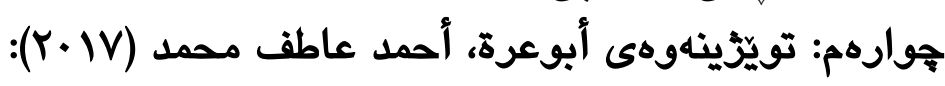

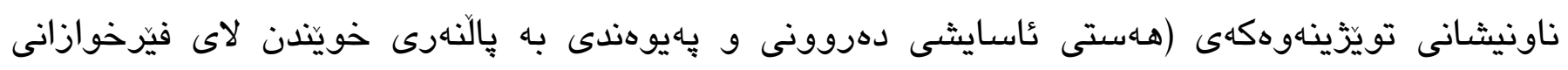

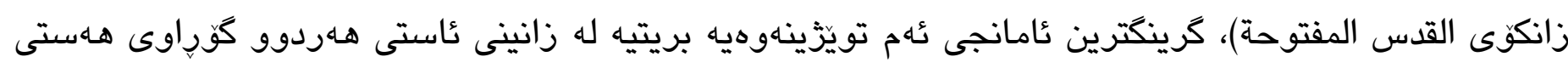

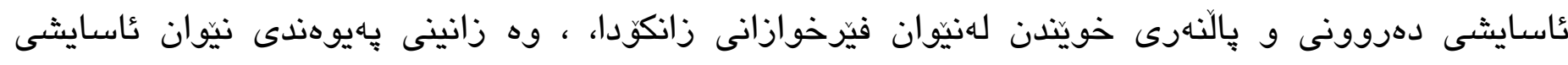

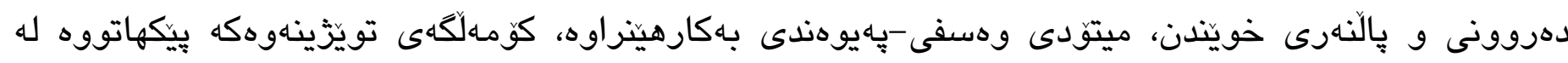
(TVYT)

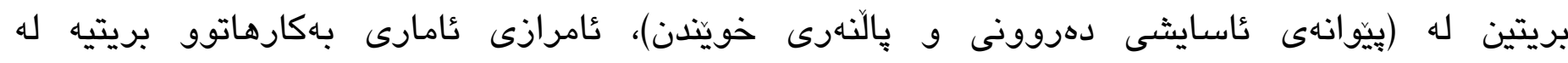

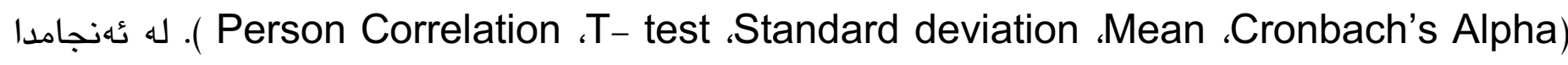

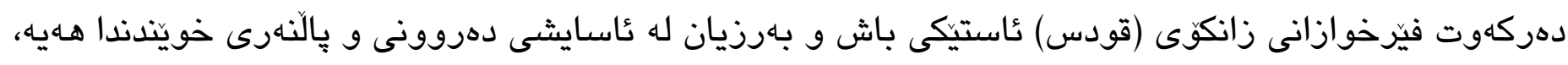

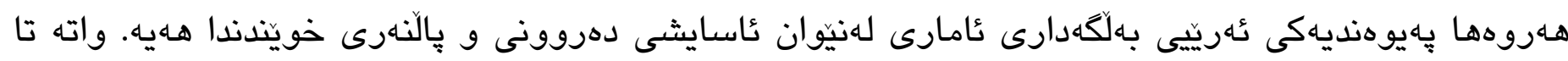

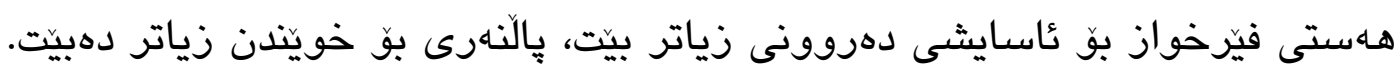

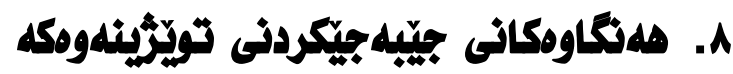

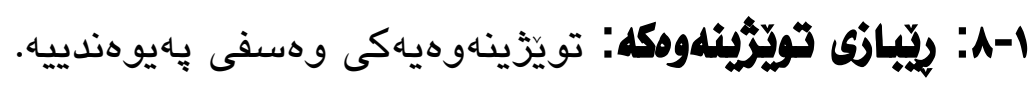

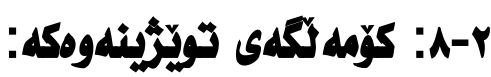

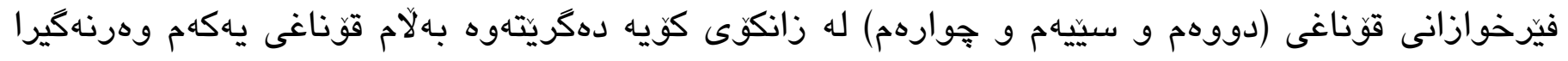

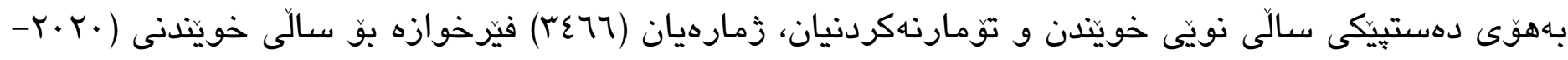

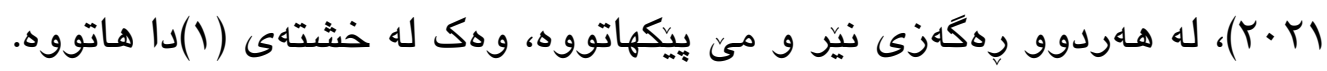


خشتهى زماره (1)

كومهالكهى تويّزينهوهك زماره

\begin{tabular}{|c|c|c|c|c|c|c|}
\hline فيّرَى كُشتى & فَّمارهى & 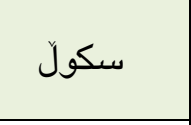 & j. & فَّمارهى & فاكهلتى & ز. \\
\hline & $r \cdot r$ & 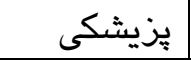 & .1 & IIrV & ي ي يَروهرده & .1 \\
\hline & 177 & وهـروهردهى & .4 & $09 \mathrm{~V}$ & |زانست و تهندروستى & tr \\
\hline & & & & VRr & زانسته مروّثايهتى و كوَمالاّييهتيهكان & r \\
\hline & & & & ו & 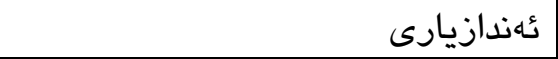 & $\varepsilon$ \\
\hline rะา7 & rin & & & $r \cdot 9 \Lambda$ & كوّى كَثتى & \\
\hline
\end{tabular}

r-A: نهونله تويَّرينهومكه:

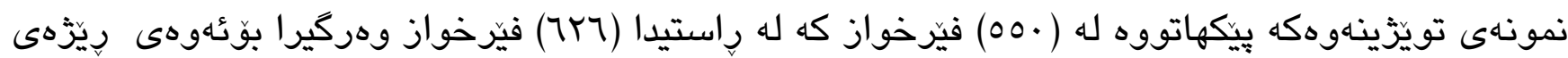

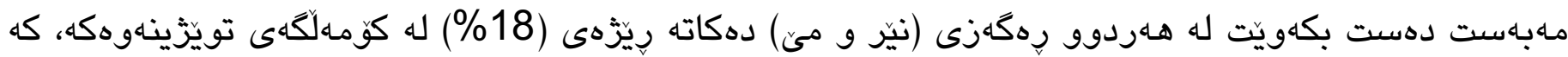

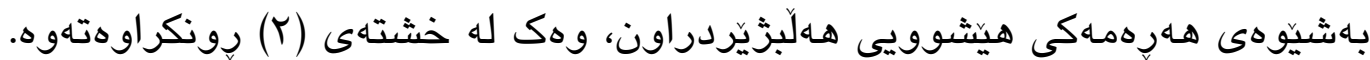

خشتهى زماره (Y)

\section{نمونهى تويزّينهوهكه}

\begin{tabular}{|c|c|c|c|c|c|c|c|}
\hline 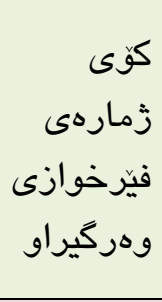 & 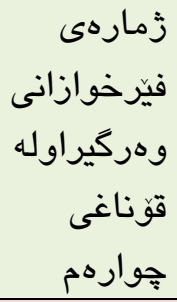 & 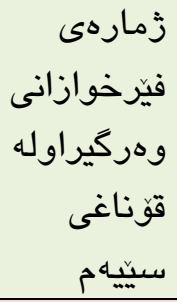 & فيّرخوازانى & فئرى & بهاش & فاكهلتى & $\dot{j}$ \\
\hline$\varepsilon Y$ & $1 \varepsilon$ & $1 \varepsilon$ & $1 \varepsilon$ & זrו & كوردى & \multirow{7}{*}{$\begin{array}{l}3 * \\
3 \\
3 \\
0 \\
7 \\
0\end{array}$} & .1 \\
\hline$\varepsilon Y$ & $1 \varepsilon$ & $1 \varepsilon$ & $1 \varepsilon$ & $|r|$ & عـرهبى & &.$r$ \\
\hline$\varepsilon Y$ & $1 \varepsilon$ & $1 \varepsilon$ & $1 \varepsilon$ & IYT & ئينكليزى & &.$r$ \\
\hline$\varepsilon Y$ & $1 \varepsilon$ & $1 \varepsilon$ & $1 \varepsilon$ & $17 V$ & جوكرافيا & & $\varepsilon$ \\
\hline$\varepsilon r$ & $1 \varepsilon$ & $1 \varepsilon$ & $1 \varepsilon$ & 171 & ميَزَوو & & .0 \\
\hline$\varepsilon r$ & $1 \varepsilon$ & $1 \varepsilon$ & $1 \varepsilon$ & 1.7 & دهرونزانى & & .7 \\
\hline$\varepsilon r$ & $1 \varepsilon$ & $1 \varepsilon$ & $1 \varepsilon$ & IrA & 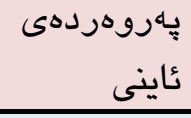 & &.$V$ \\
\hline$\varepsilon r$ & $1 \varepsilon$ & $1 \varepsilon$ & $1 \varepsilon$ & ITr & كيميا & \multirow{6}{*}{$\begin{array}{l}\frac{.7}{3} \\
.3 \\
9 \\
.7 \\
.9 \\
3 \\
.3 \\
.3\end{array}$} &.$\wedge$ \\
\hline$\varepsilon r$ & $1 \varepsilon$ & $1 \varepsilon$ & $1 \varepsilon$ & שTו & فيزيا & & .9 \\
\hline$\varepsilon Y$ & $1 \varepsilon$ & $1 \varepsilon$ & $1 \varepsilon$ & 91 & بايوّلوّجى & & .1 . \\
\hline$\varepsilon r$ & $1 \varepsilon$ & $1 \varepsilon$ & $1 \varepsilon$ & $1 \cdot \varepsilon$ & ماتماتيك & & .11 \\
\hline$\varepsilon r$ & $1 \varepsilon$ & $1 \varepsilon$ & $1 \varepsilon$ & $1 \cdot r$ & مايكّديكة & & $.1 Y$ \\
\hline 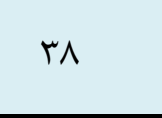 & $1 \varepsilon$ & 1. & $1 \varepsilon$ & $\varepsilon r$ & سلينيكّلَّل & & $.1 \%$ \\
\hline
\end{tabular}




\begin{tabular}{|c|c|c|c|c|c|c|}
\hline$\varepsilon Y$ & $1 \varepsilon$ & $1 \varepsilon$ & $1 \varepsilon$ & $r \cdot r$ & سكولَى يَيشكى & $.1 \varepsilon$ \\
\hline$\varepsilon r$ & $1 \varepsilon$ & $1 \varepsilon$ & $1 \varepsilon$ & 177 & 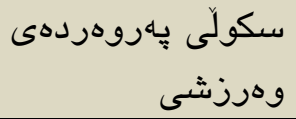 & .10 \\
\hline TYY & rI. & $r \cdot T$ & rI. & $19 r \varepsilon$ & كوى كَثتى & \\
\hline
\end{tabular}

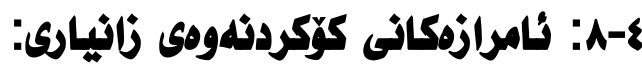

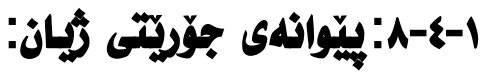

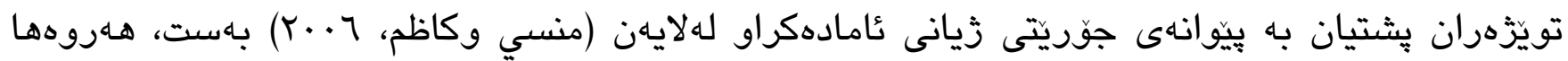

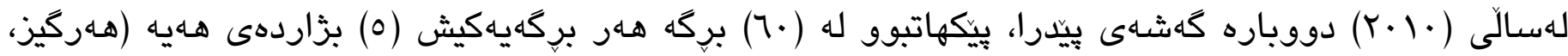

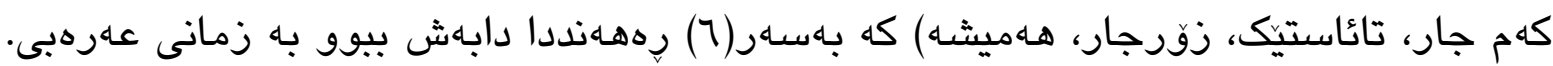

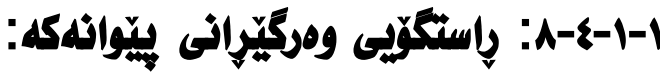

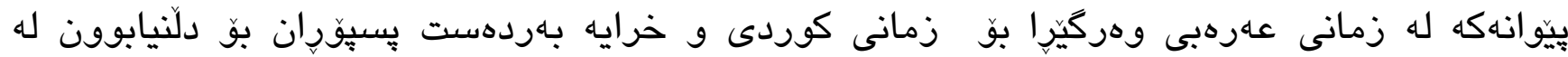

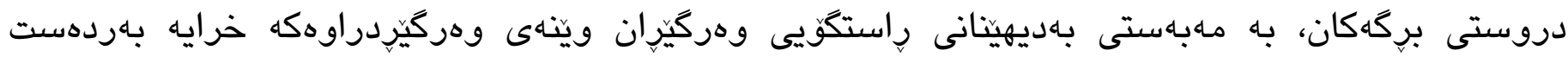

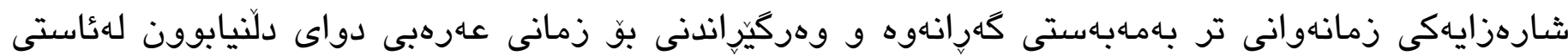

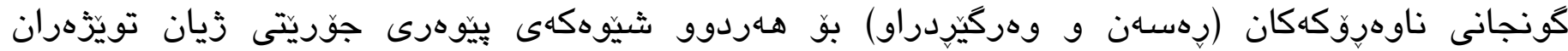

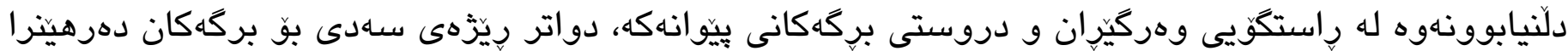

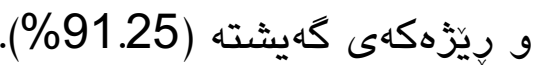

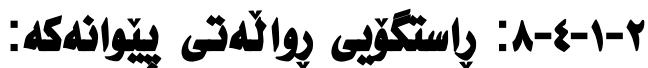

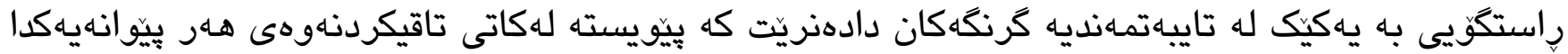

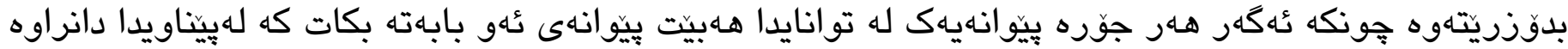

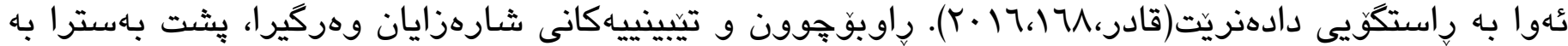

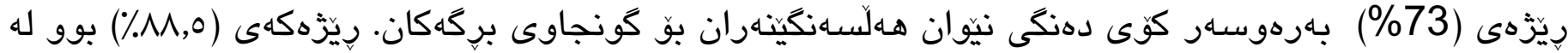

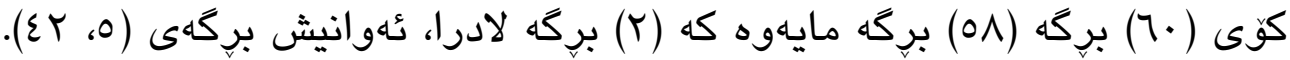

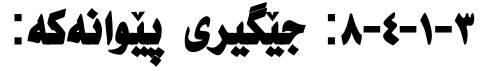

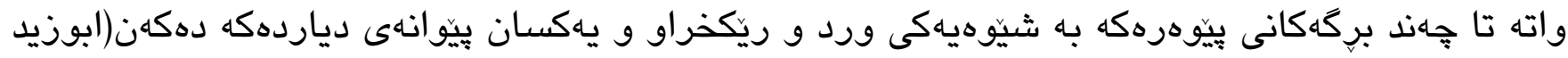

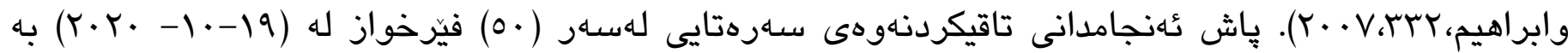

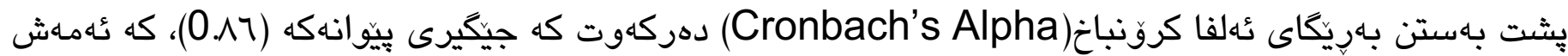

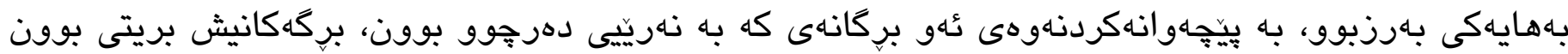

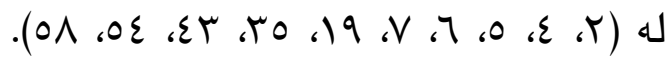




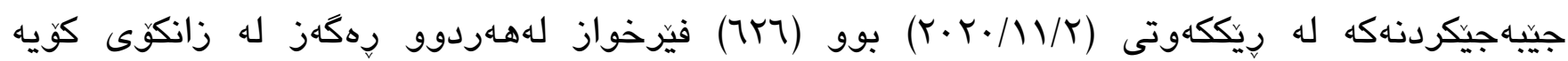

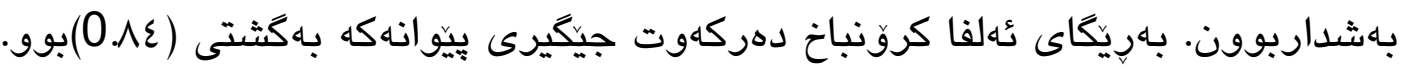

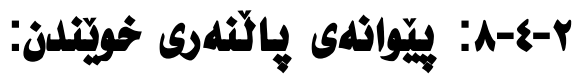

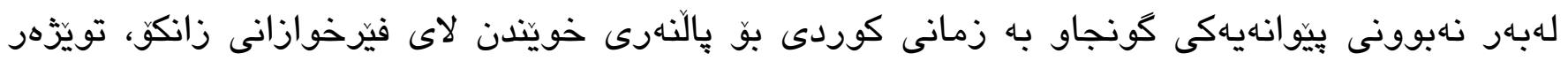

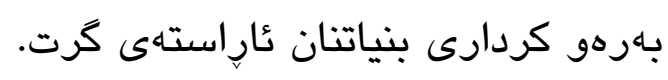
(Allen \& Yen) دادهروات:

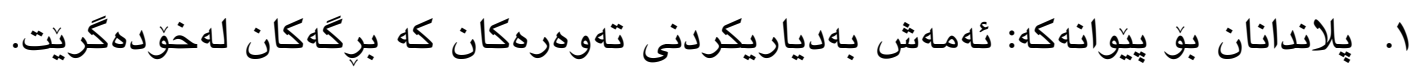

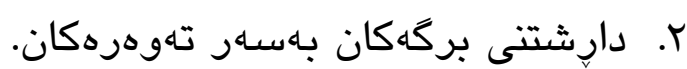

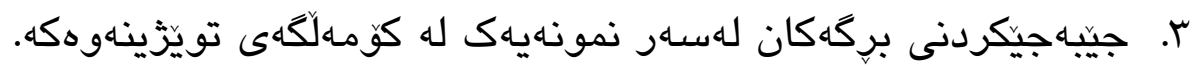

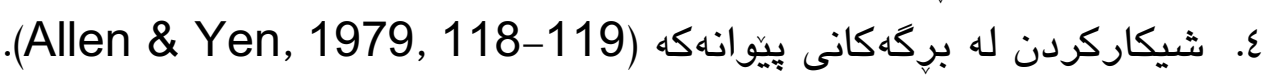

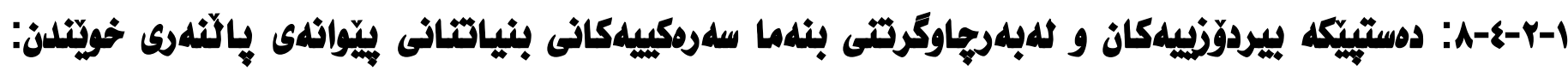

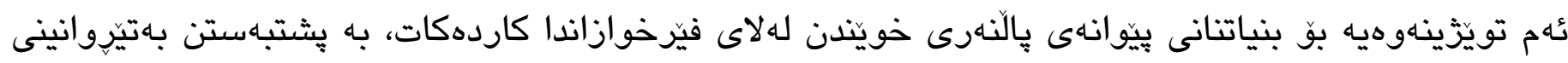

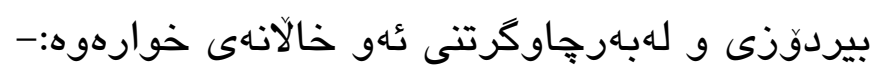

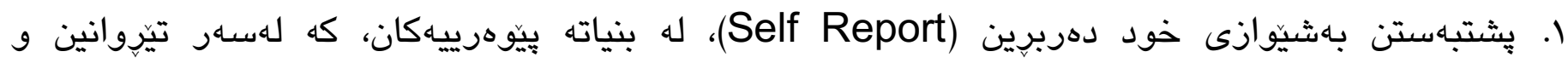

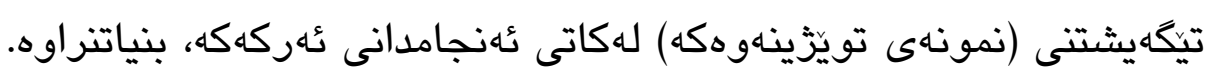

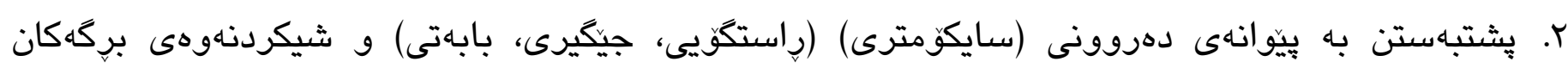

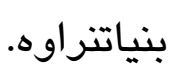

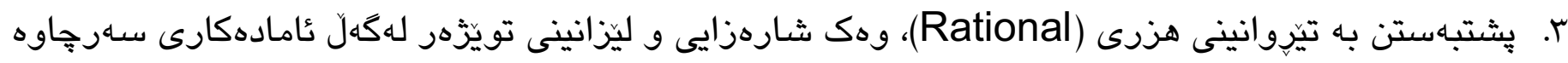

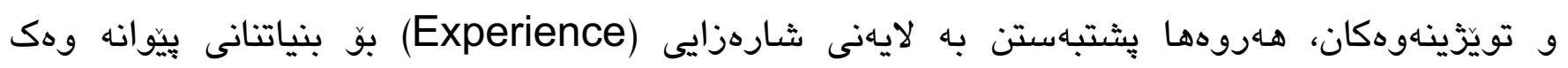

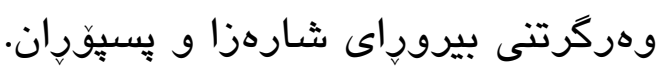

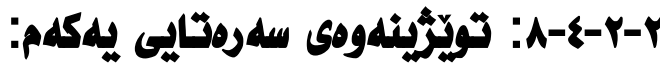

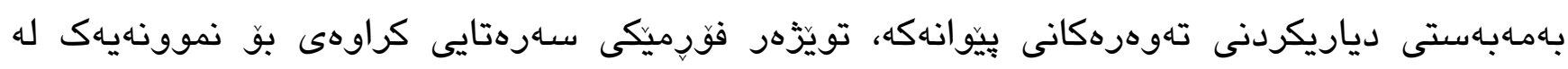

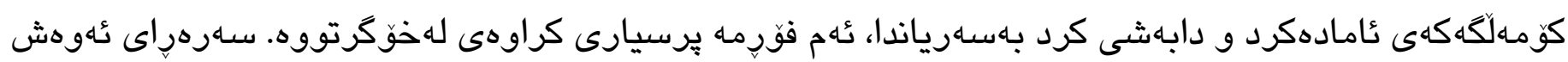

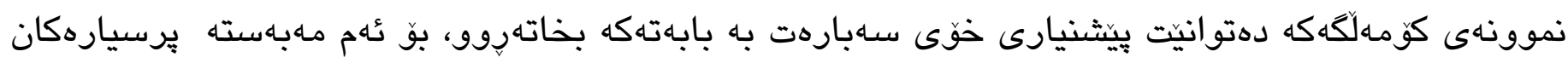

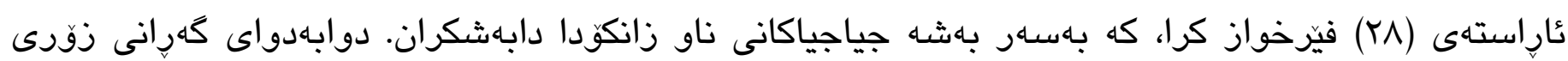

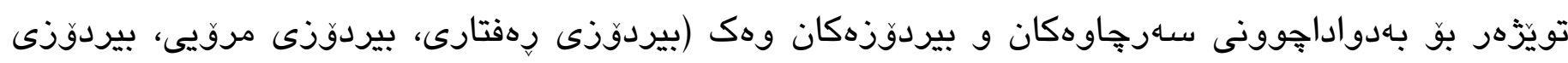

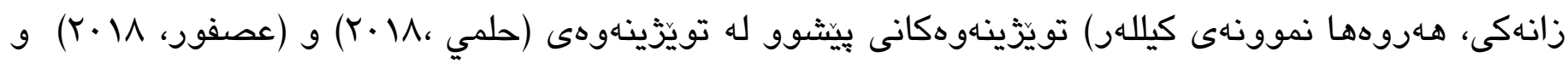

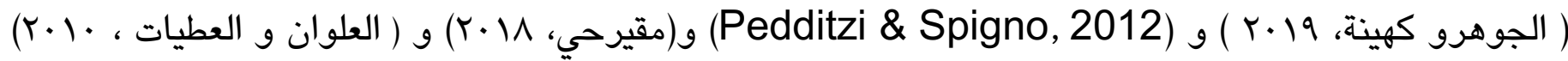

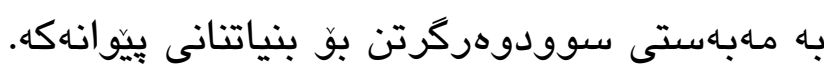




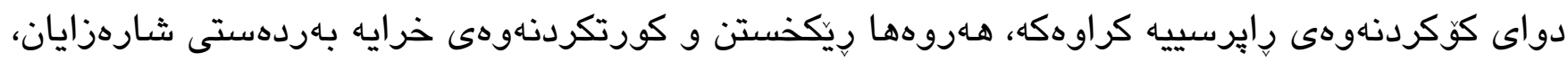

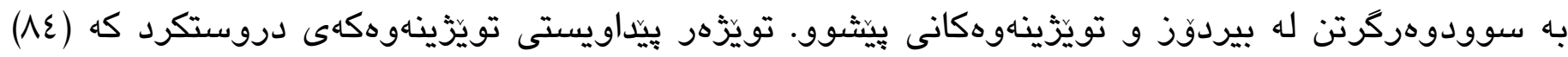

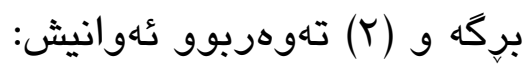

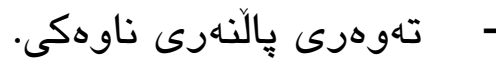

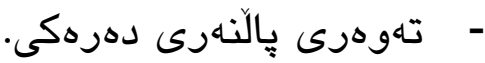

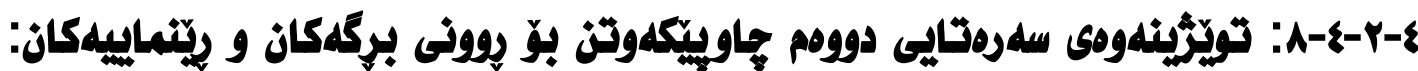

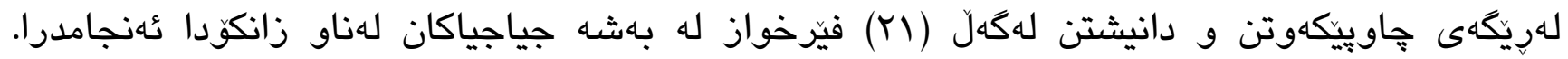

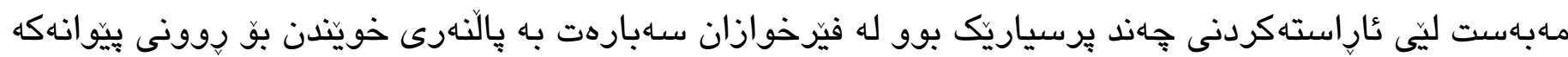

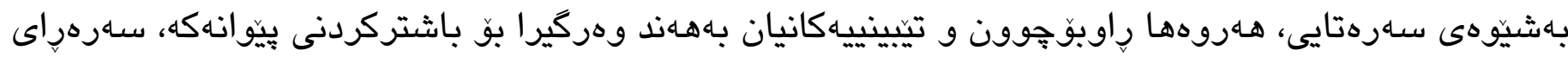

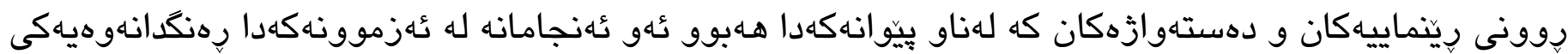

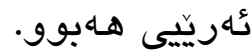

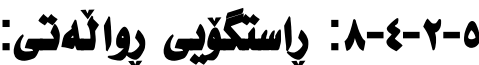

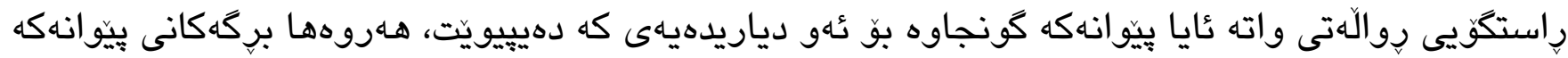

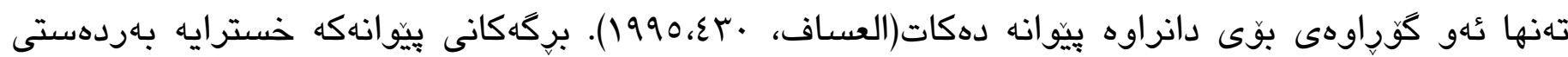

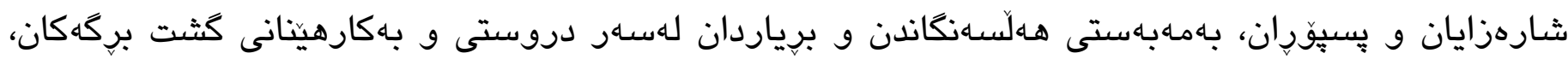

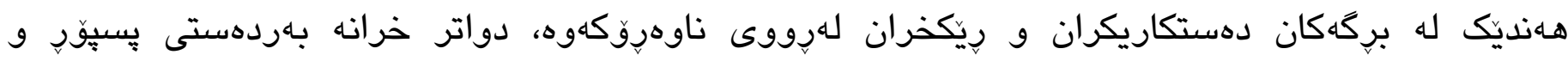

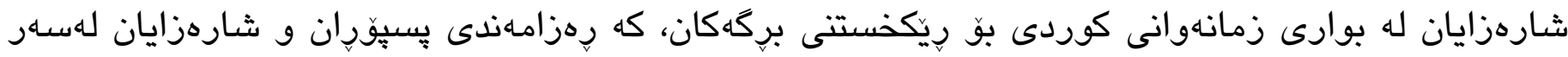

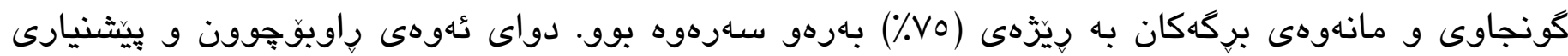

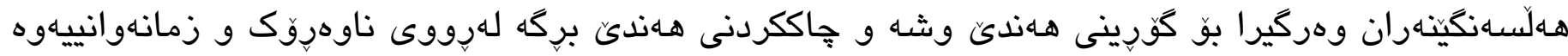

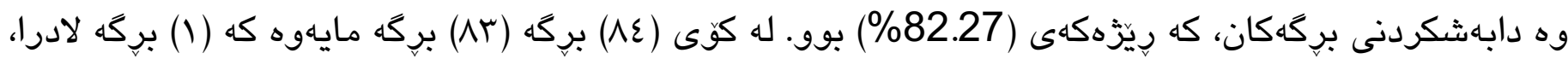

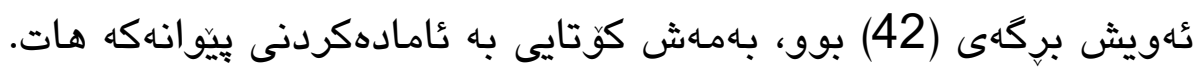




\section{يَّيكارهكانى (Procedures) دروستكردنى ييّوانهى بالنهارى خويندن:}
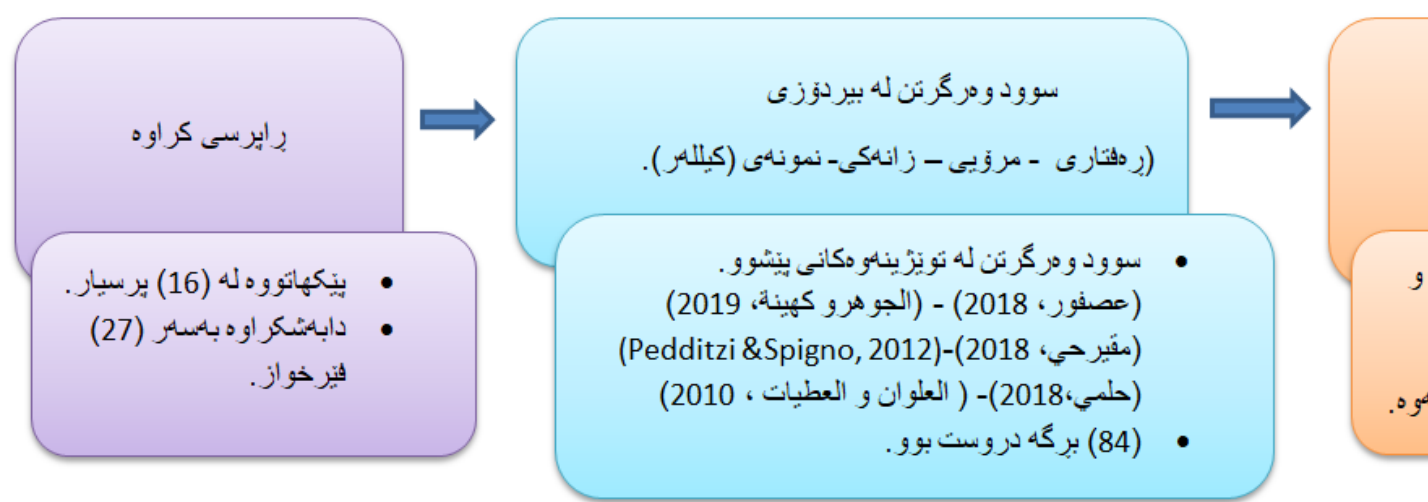

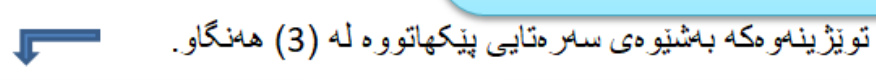
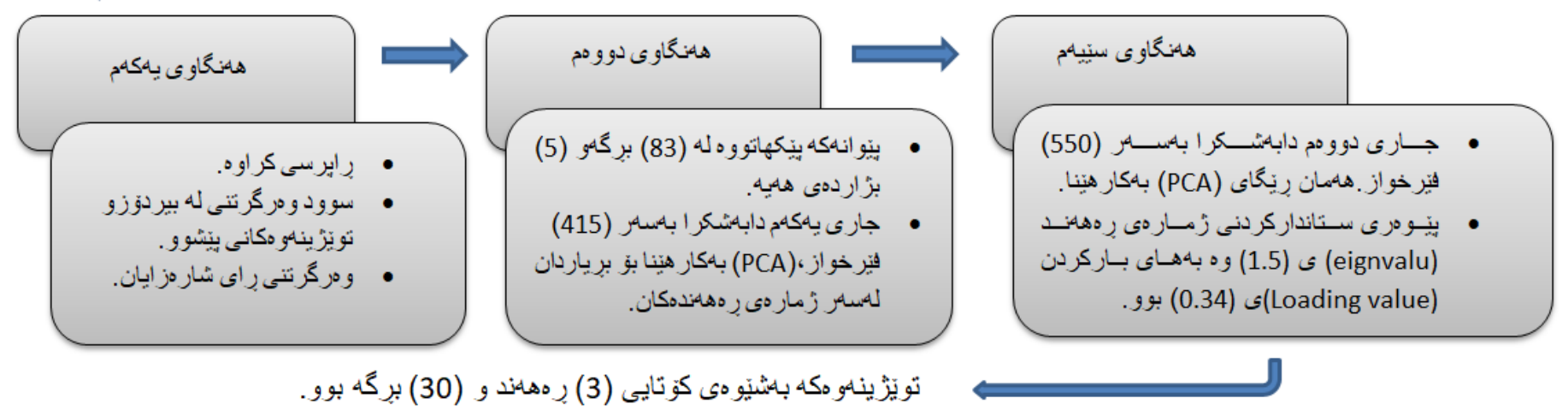

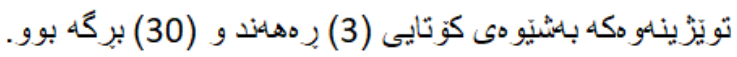

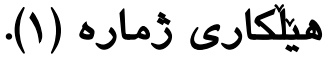

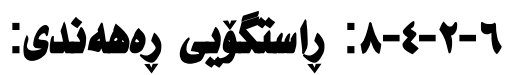

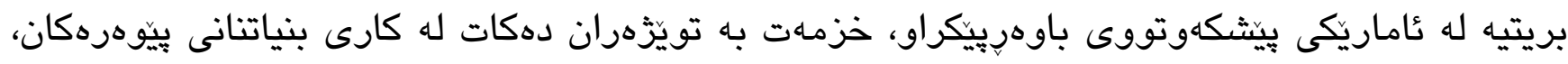

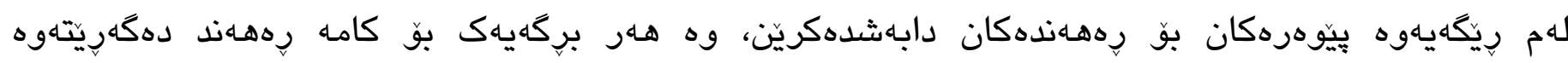

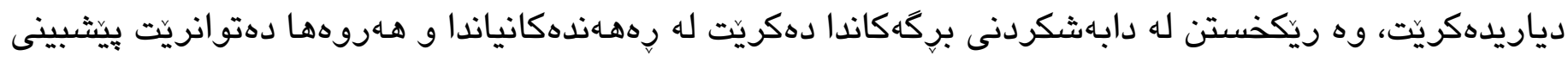

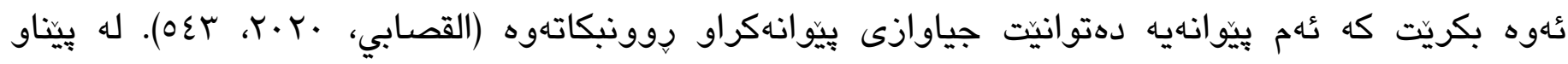

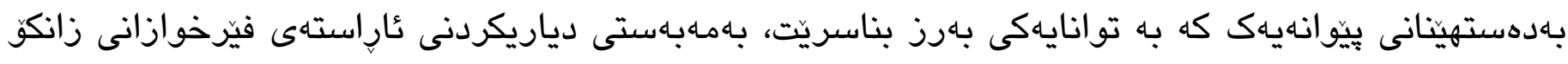

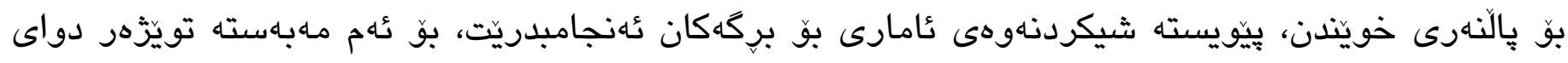

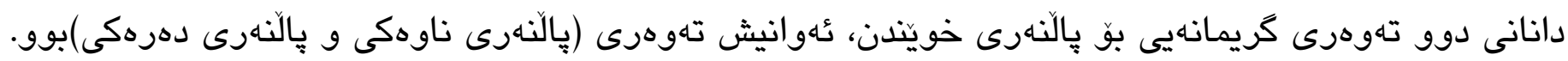

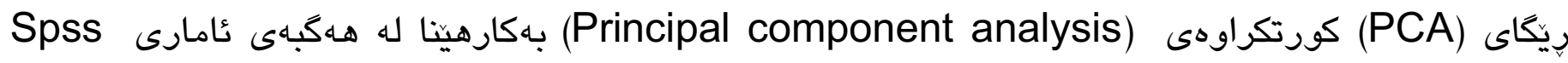

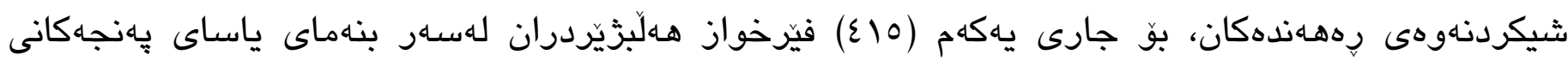

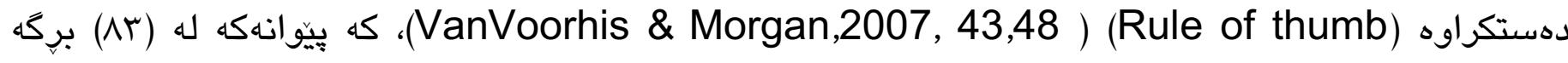

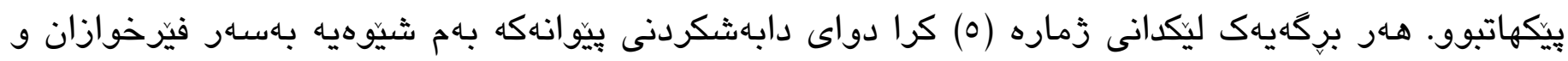

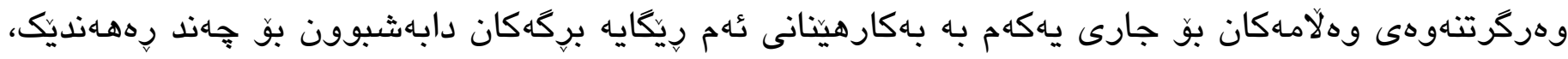

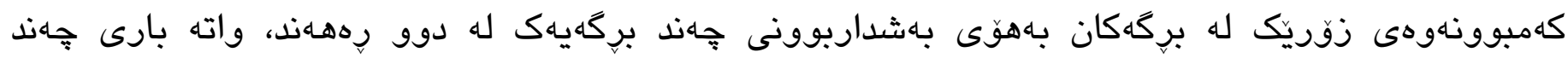

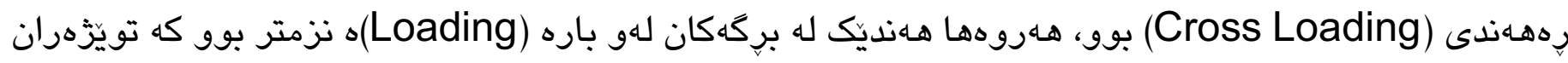

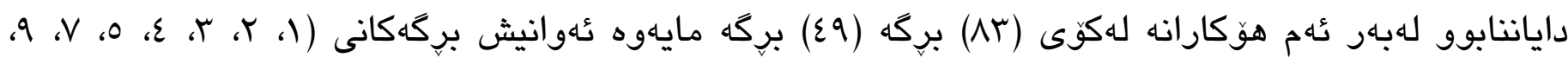

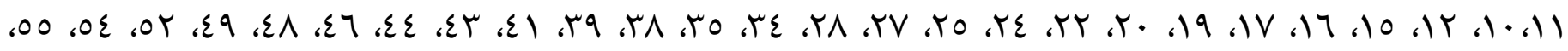
7.

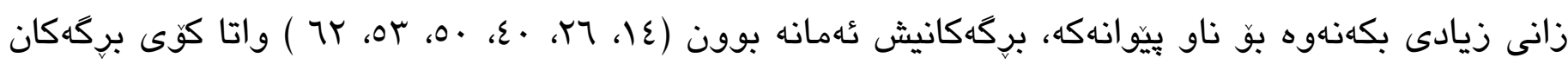




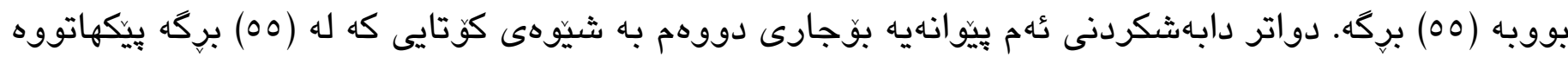

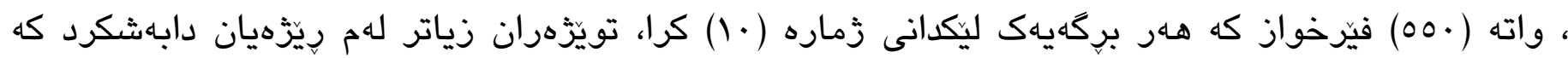

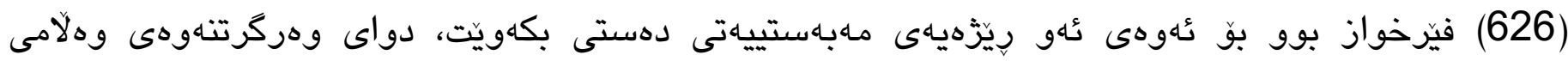

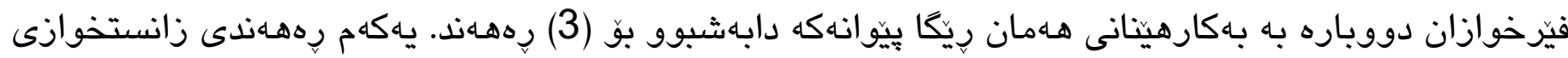

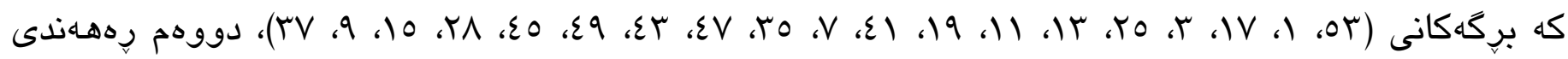

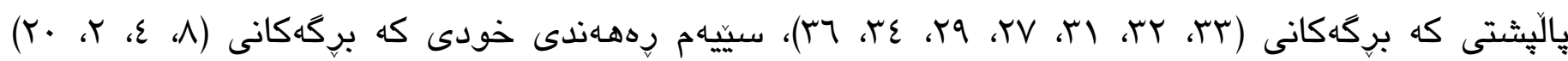

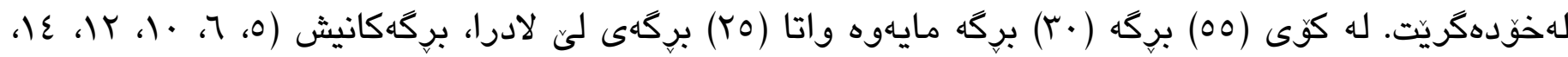

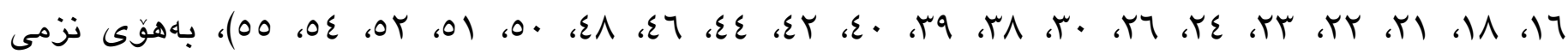

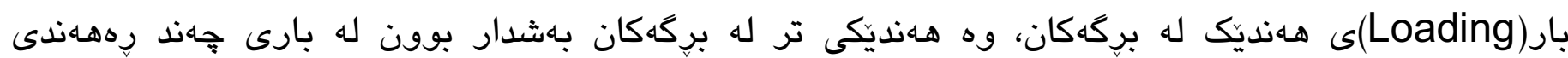
(Cross Loading)

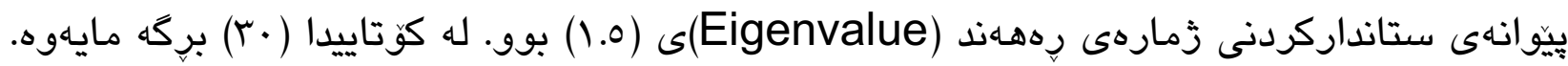

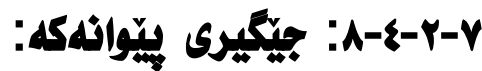

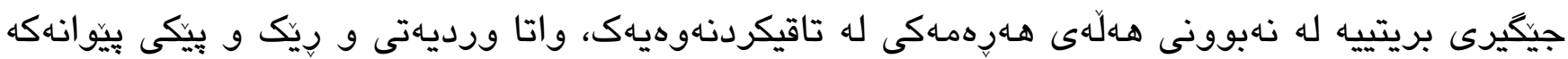

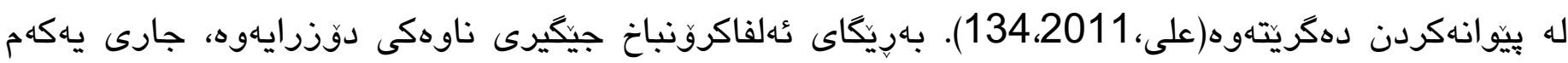

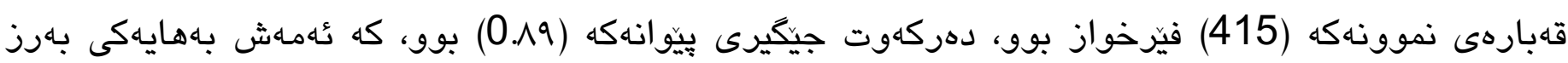

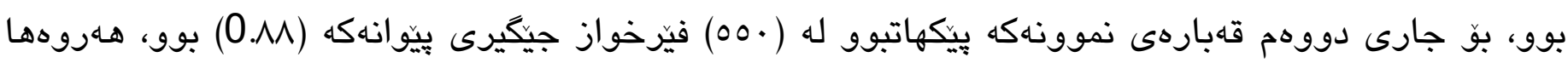

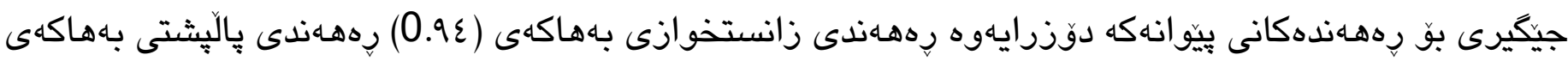

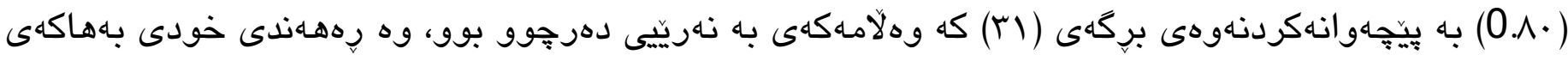
(O.V• ) بوو كه له خشتهى (r) (Uا هاتووه.

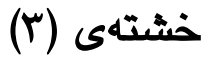

\begin{tabular}{|c|c|c|c|c|}
\hline ئهلفاكرونباخ & $\begin{array}{c}\text { باركردن } \\
\text { Loading } \\
\text { Value }\end{array}$ & بركه & $j$ & ردهـندهان \\
\hline \multirow{10}{*}{0.94} & 0.769 & بهدهستهينانى وهلامى كونجاوى برسيارهكانم وام ليدهكات زياتر بخويَنم. & 53 & \multirow{10}{*}{ 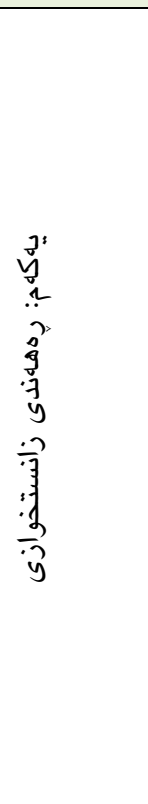 } \\
\hline & 0.754 & 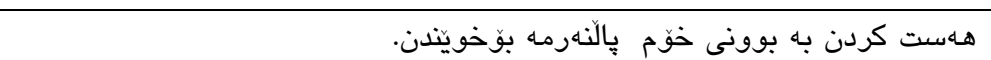 & 1 & \\
\hline & 0.750 & حهز به جالاكى مانكانه و سالانه دهكهم تايبهت بهو بهشهى تييدا دهخويّنم. & 17 & \\
\hline & 0.750 & 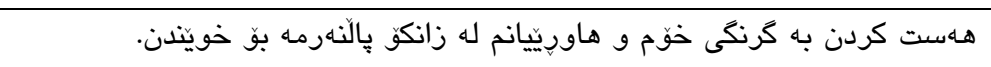 & 3 & \\
\hline & 0.747 & هاوكاريكردنم بو جارهسهركردنى كيشه كانم بالَّهره بوَئهوهى بخوينّم. & 25 & \\
\hline & 0.738 & 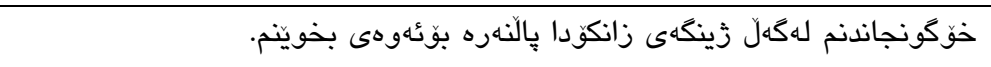 & 13 & \\
\hline & 0.725 & 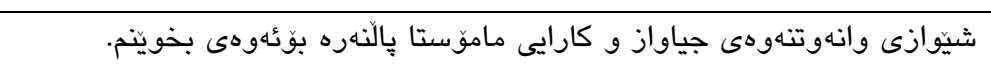 & 11 & \\
\hline & 0.713 & خويتدنم به مهبهستى فيّربوونه، نهك بهدهستهينانى نمره. & 19 & \\
\hline & 0.712 & 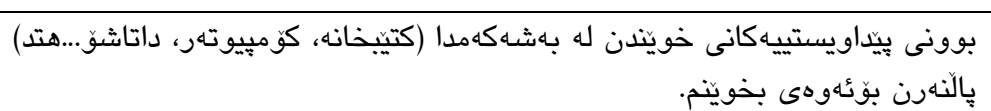 & 41 & \\
\hline & 0.706 & بهخشينى زانيارى به هاوريكانم بِالنهرمها بو خويندن. & 7 & \\
\hline
\end{tabular}




\begin{tabular}{|c|c|c|c|c|}
\hline & 0.703 & دروستكردنى كروويى خويندن بِالنهره بوّم. & 35 & \\
\hline & 0.685 & 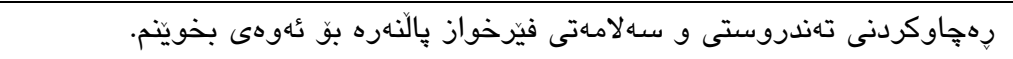 & 47 & \\
\hline & 0.684 & تيكاهيشتى مامؤستا له بارودوخى فيّرخواز بهردهواميم بِيّددات بو خويندن. & 43 & \\
\hline & 0.677 & 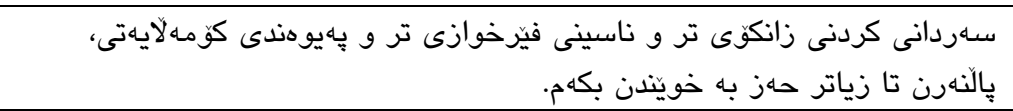 & 49 & \\
\hline & 0.653 & به تهنيا دانيشتن له ذووردكهمدا بِالذهره بو ئهوهى بخوينم. & 45 & \\
\hline & 0.631 & 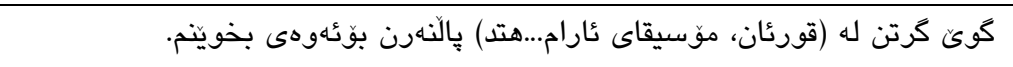 & 28 & \\
\hline & 0.603 & حهز به ئهنجامدانى وانهان دهكهم به شيّوهى بِراكتيكى له (تاقيكه، مهيدانى). & 15 & \\
\hline & 0.601 & دهكهريمّهوهو بِرسيار دهكهم بو ئهو شتانهى له بابهتى خويندندا ناروونه له لام. & 9 & \\
\hline & 0.558 & 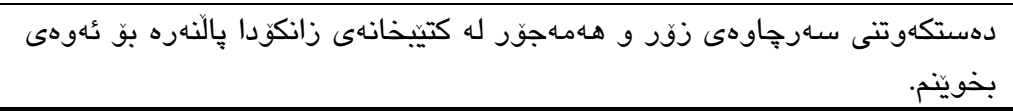 & 37 & \\
\hline \multirow{7}{*}{0.80} & 0.710 & تازهكاريى (كَّرانكارى له زينكهى ناويوّل) دا هانم دددات بوْوينّنن. & 33 & \multirow{7}{*}{ 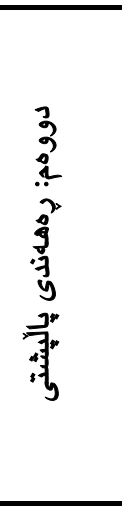 } \\
\hline & 0.695 & رِايوّرت نوسين و سيميناركردن بِالّهرن بو ئهوهى بخوينّم. & 32 & \\
\hline & 0.657 & سيستهمى خويندنى وهرزى(كورسات) بالنهرمها بو خويَندن. & 31 & \\
\hline & 0.655 & 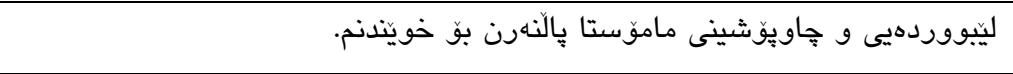 & 27 & \\
\hline & 0.637 & 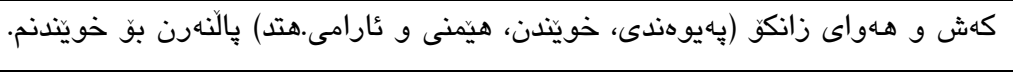 & 29 & \\
\hline & 0.604 & حهزبه كفتوكَكردنى زانستى و بهشداريكردنى روّذانهى ناو بِّل دهكهم. & 34 & \\
\hline & 0.586 & كرنكى داهاتووى بهشهكهم وام لئ دهكات بخوينم. & rา & \\
\hline \multirow{4}{*}{0.70} & 0.723 & 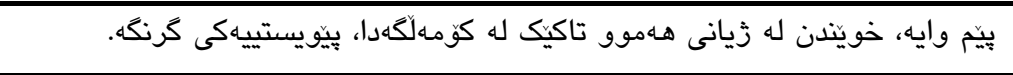 & 8 & \multirow{4}{*}{ 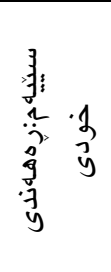 } \\
\hline & 0.718 & به دهستهيّانى رهزامهندى خودا بالآنهرمه بوخويتّن. & 4 & \\
\hline & 0.639 & 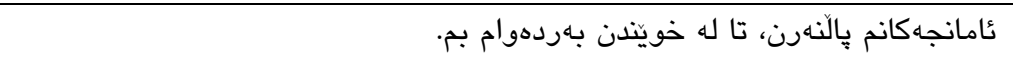 & 2 & \\
\hline & 0.617 & ئاواته خوازى به دهستهينانى بروانامهم له خويندنى زانكودا. & 20 & \\
\hline
\end{tabular}

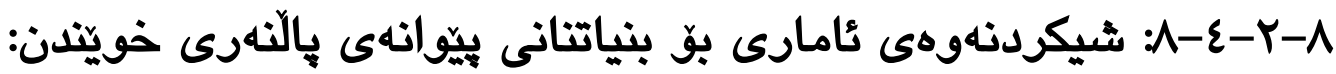

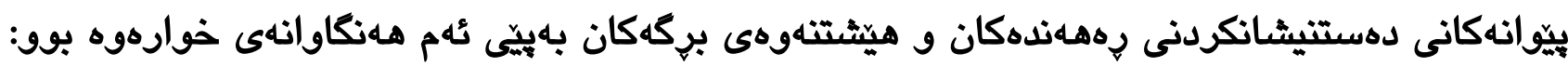

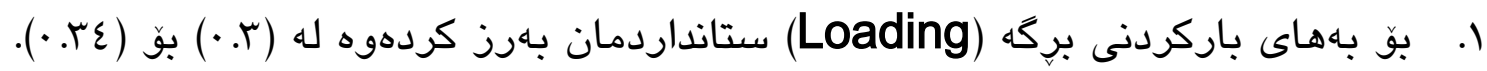

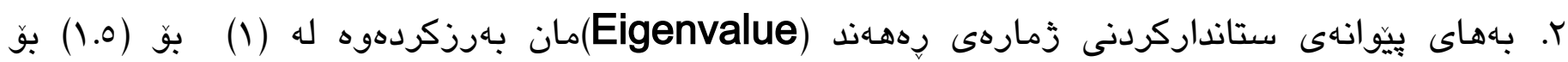

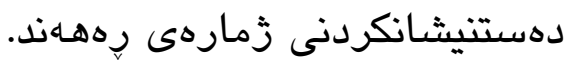

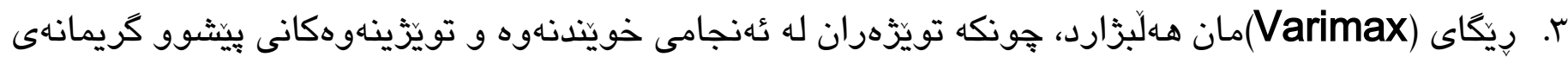

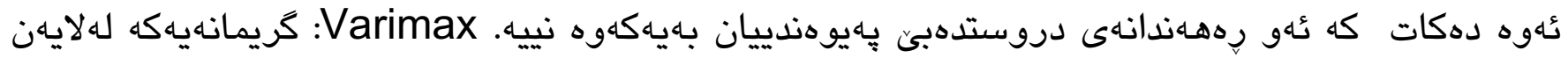

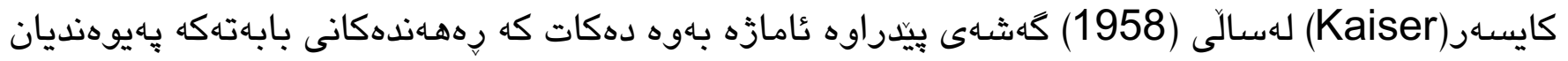

باهيهكهوه نييه (Abdi,2003,3 ).

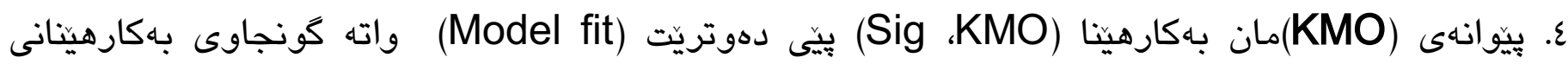

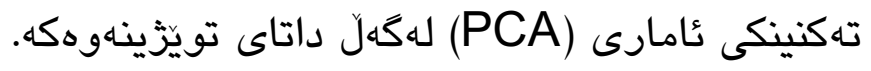

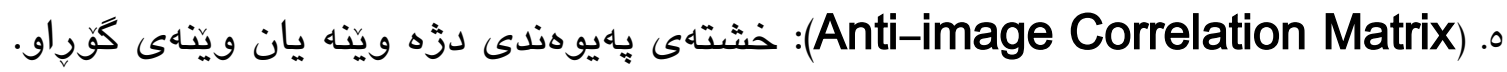




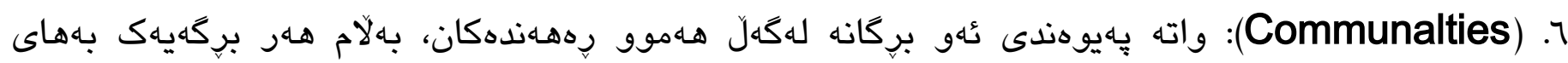

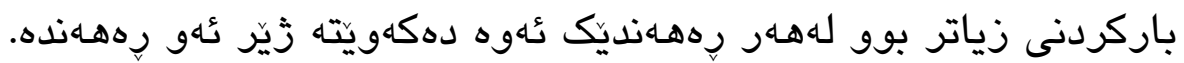

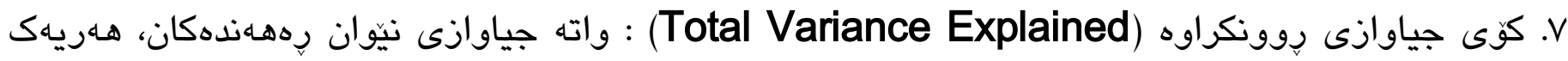

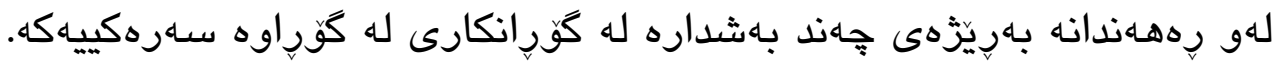

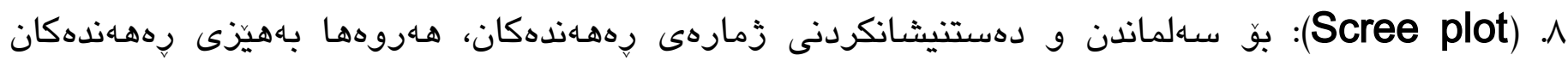
دياريدهات بهشيّوهى هيلّارى.

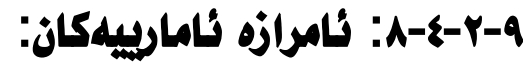

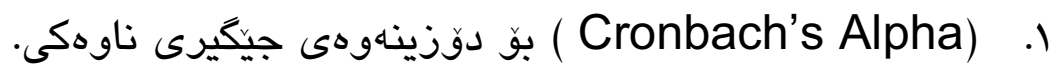

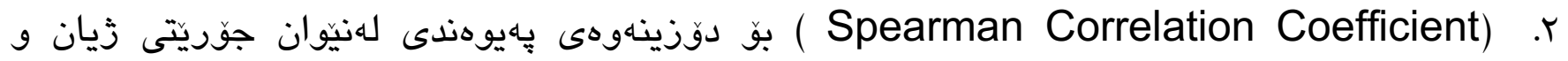

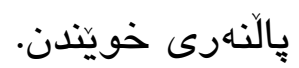

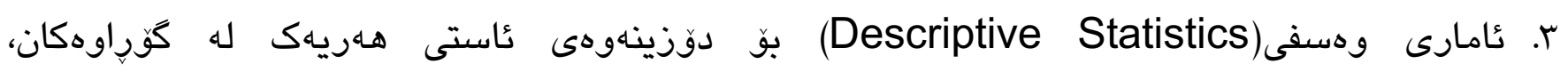

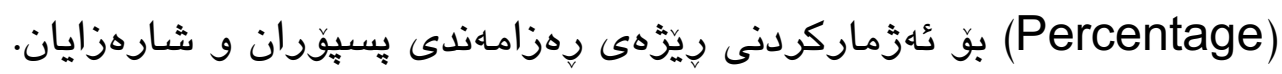

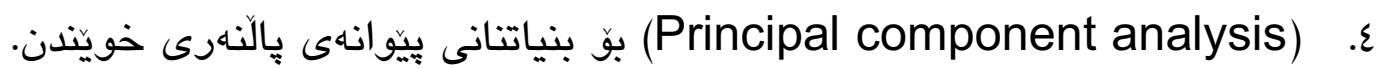

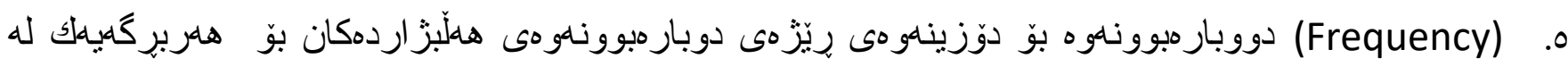
بِيَّو انهكان.

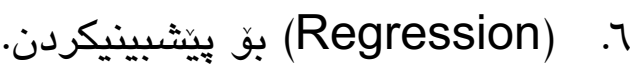

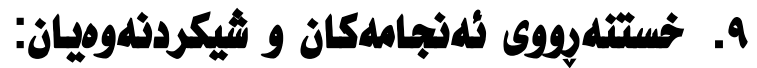

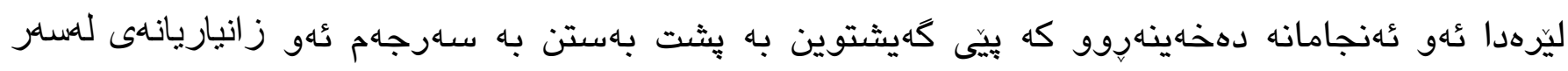

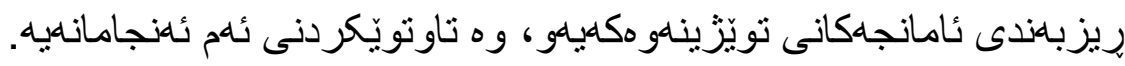

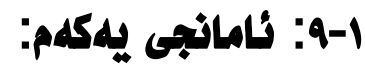

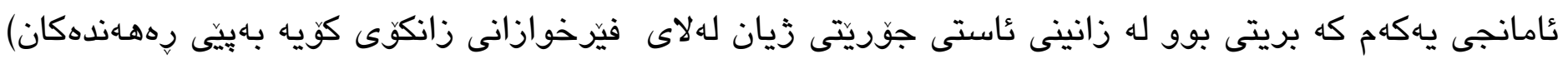

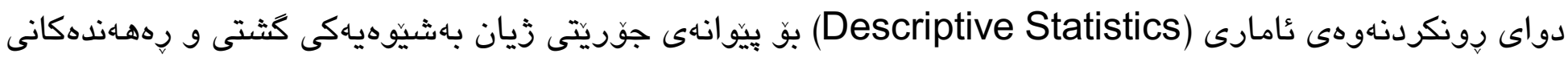

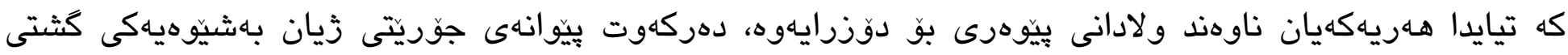
(M:I 9r.97, SD:Fr.VA)

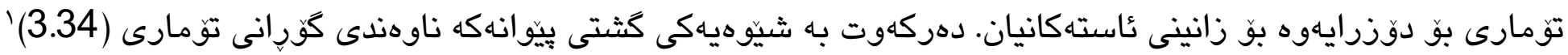

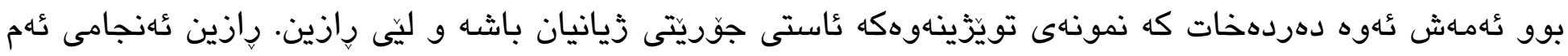

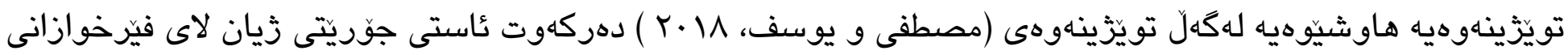

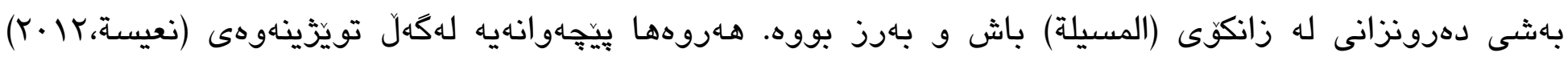

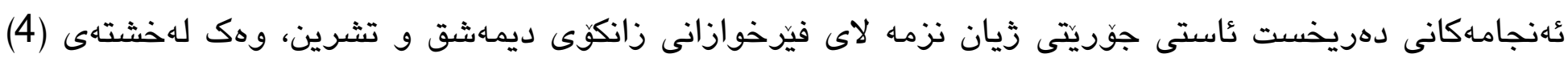

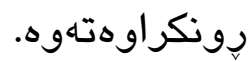


خشتهى (ع) نارئ)

خستنهرووى ئامارى بو بيّوانهى جوّريّتى زيان

\begin{tabular}{|c|c|c|c|c|c|c|}
\hline $\begin{array}{l}\text { ناوهندى كَّرانى تومار } \\
\text { transfer record }\end{array}$ & $\mid$\begin{tabular}{|l} 
لادانى بيّوهرى \\
Std. Deviation
\end{tabular} & $\begin{array}{l}\text { ن اوهند } \\
\text { Mean }\end{array}$ & ذ. نمونه & 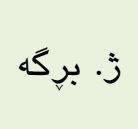 & جوّريتّى زيان و رهههندهكانى & j \\
\hline 3.34 & r.VA & 197.97 & 00 . & $0 \wedge-1$ & 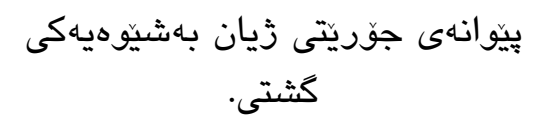 & \\
\hline 3.38 & 4.84 & 30.43 & -0. & $9-1$ & جوَريّتى تهندروستى كَثتى. & .1 \\
\hline 3.75 & 6.94 & 37.56 & - & $19-1$. & جوّريتى زيانى خيزّانى و كومهالايهتى & r \\
\hline 3.24 & 6.63 & 32.45 & - 0 . & $r q-r$. & جوَريتيى بِهروهرده و خوينتدن. & r \\
\hline 3.25 & 5.17 & 32.55 & هo. & $r q-r$. & جوَّيتّى هـست وسوّز. & $\varepsilon$ \\
\hline 3.40 & 5.23 & 30.65 & هo. & $\varepsilon \wedge-\varepsilon$. & جوّريتى تهندروستى دهرونى. & .0 \\
\hline 3.00 & 4.05 & 30.05 & 00. & $\Delta \wedge-\varepsilon q$ & جوَّريتيَى كاتى كار كردن و & .7 \\
\hline
\end{tabular}

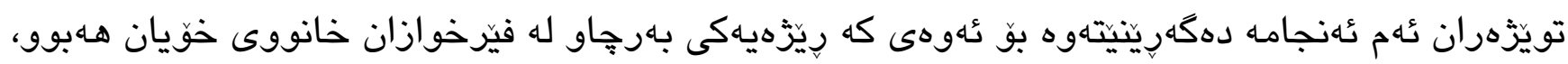

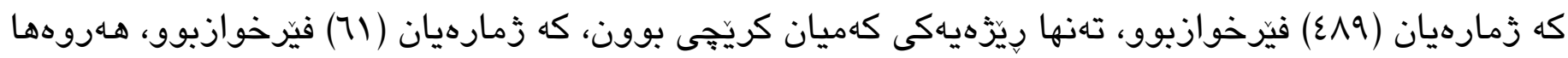

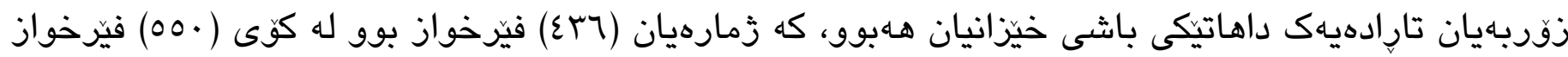

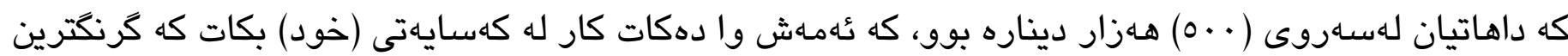

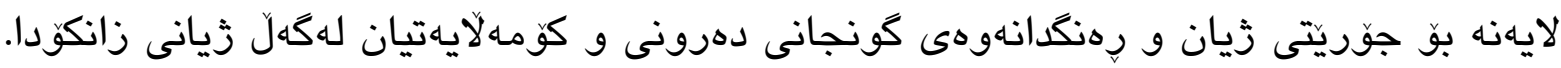

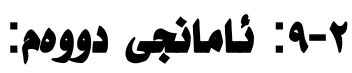

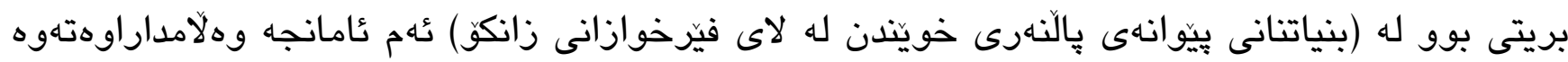

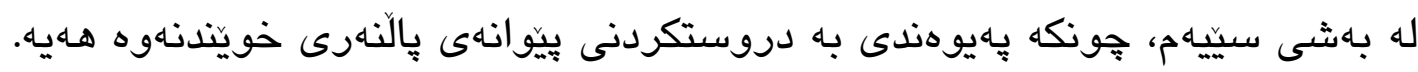

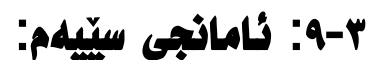

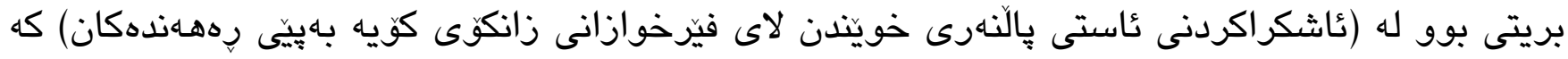

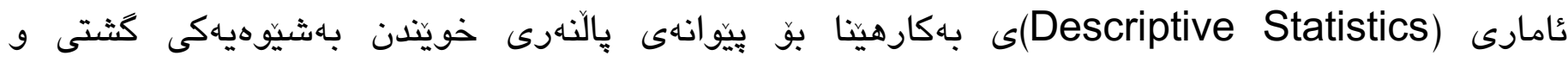

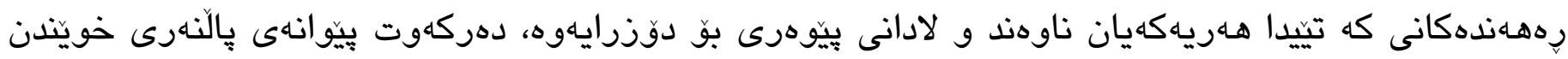

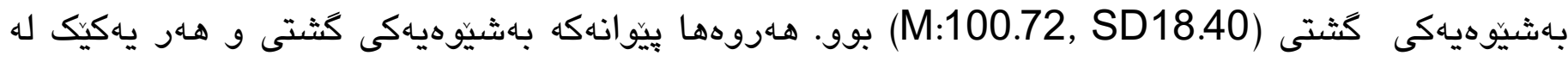

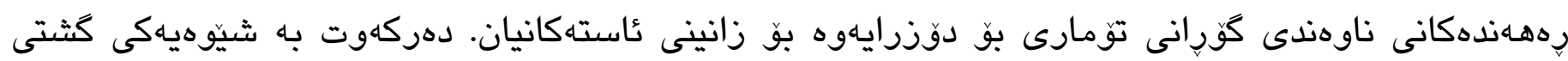

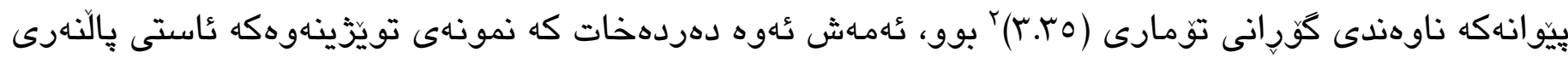




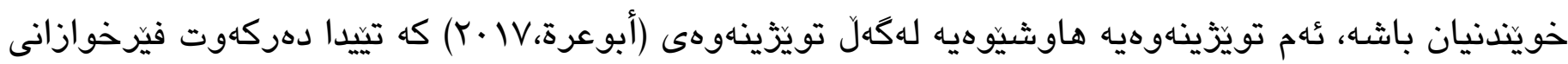

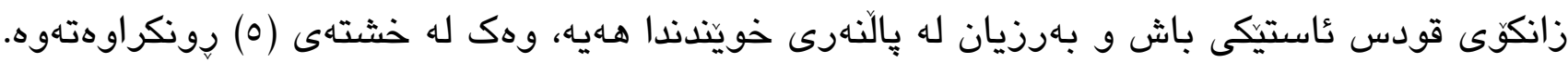

خشتهى (0)

خستنهرووى ئامارى بوّ بيّوانهى بالَّهرى خويندن

\begin{tabular}{|c|c|c|c|c|c|c|}
\hline 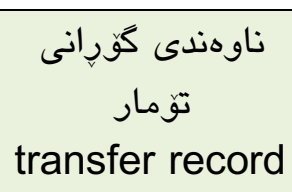 & $\begin{array}{c}\text { لادانى ييّوهرى } \\
\text { Std. } \\
\text { Deviation }\end{array}$ & $\begin{array}{l}\text { Mean } \\
\text { Mean }\end{array}$ & 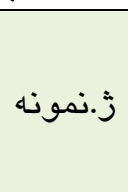 & ز زبركه & 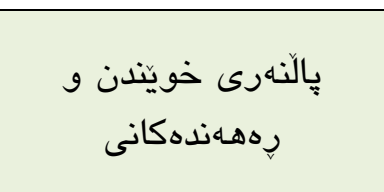 & $j$ \\
\hline 3.35 & 18.40 & 100.72 & 550 & r. & 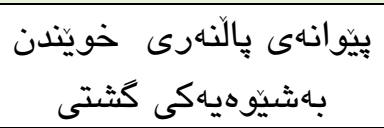 & \\
\hline r.Ir & 17.93 & 09.09 & 550 & 19 & برههندى زانستخوازى & .1 \\
\hline 3.58 & 5.74 & $r o . \cdot V$ & 550 & v & رههندنى بِالِّشتى &.$r$ \\
\hline 3.99 & 3.35 & $10.9 \mathrm{~V}$ & 550 & $\varepsilon$ & رههاندى خودى & r \\
\hline
\end{tabular}

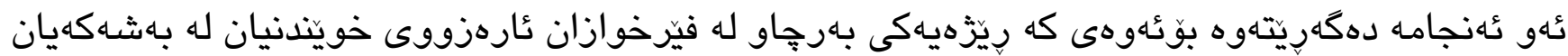

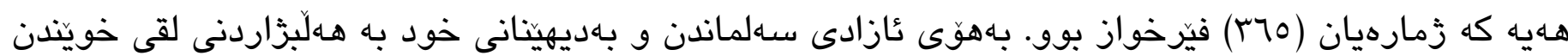

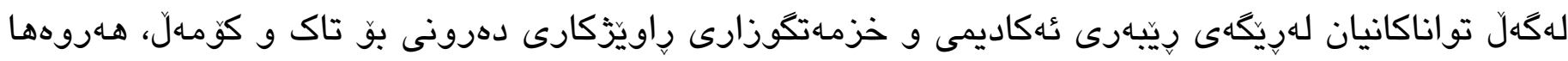

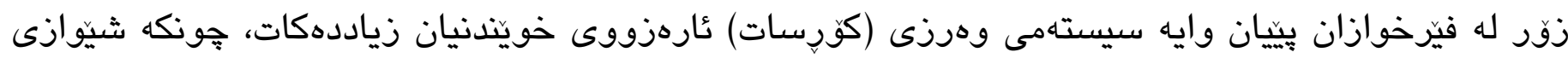

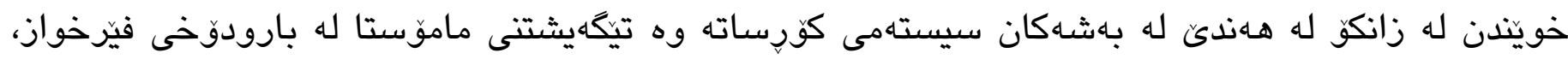

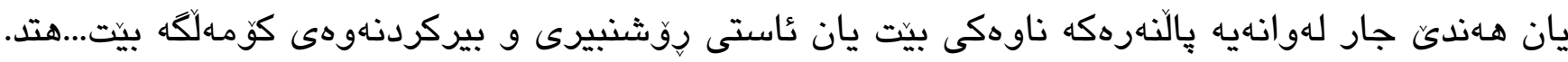

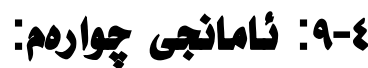

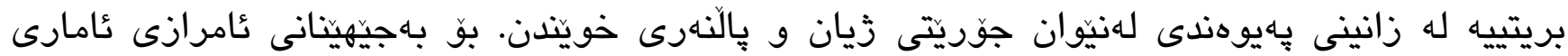

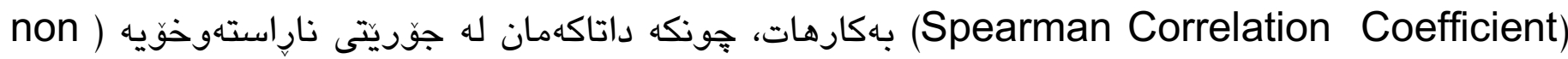

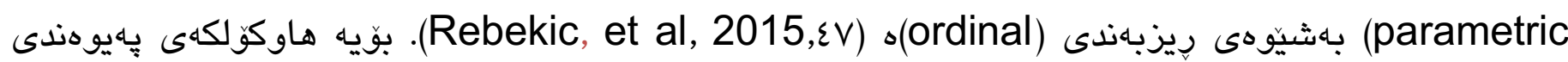

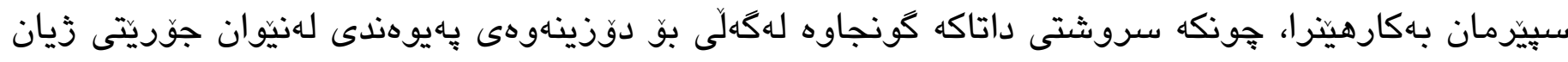

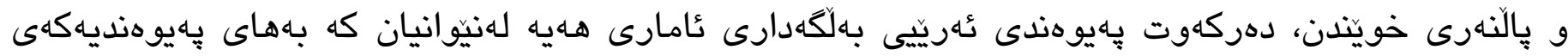

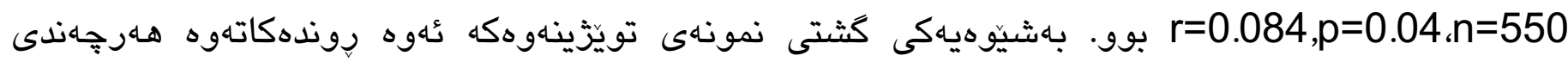

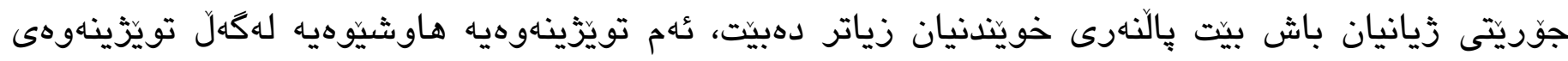

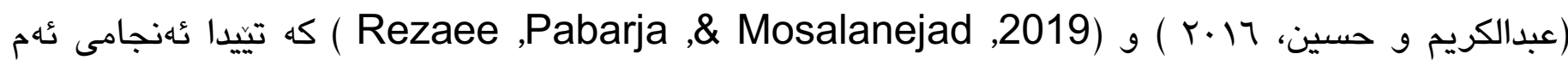

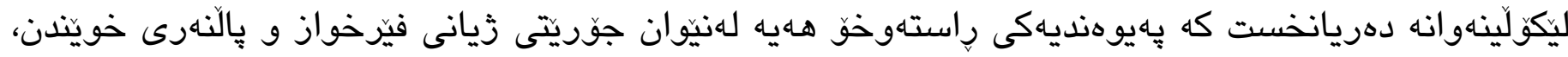

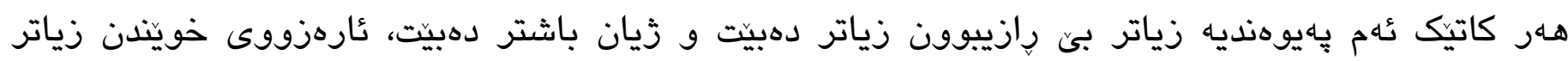

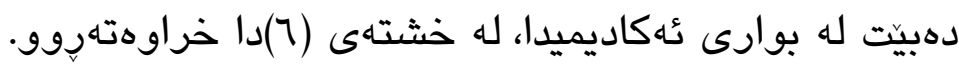


خشتهى (T)

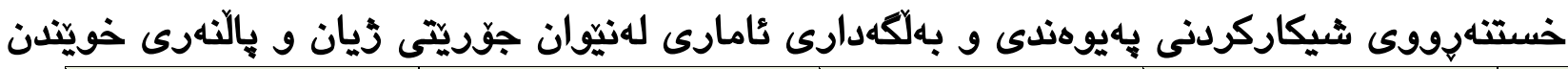

\begin{tabular}{|c|c|c|c|c|}
\hline 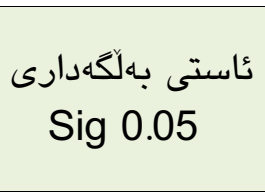 & 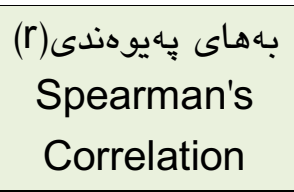 & ز. نمونه & كَّرِاو & נ. \\
\hline \multirow{2}{*}{$\cdot \cdot \varepsilon$} & \multirow{2}{*}{0.084} & \multirow{2}{*}{00.} & جوّريتيى ذيان & .1 \\
\hline & & & يالنارى خوينتدن &.$r$ \\
\hline
\end{tabular}

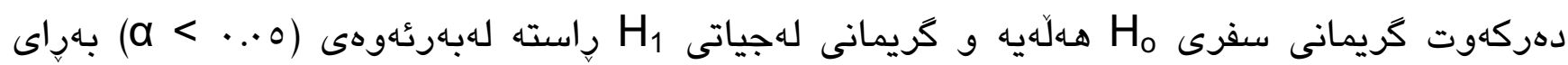

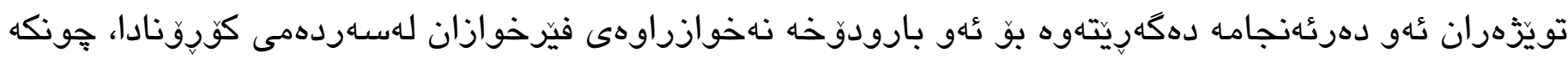

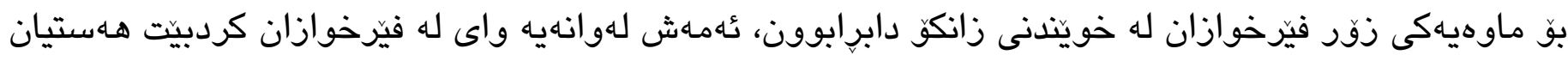

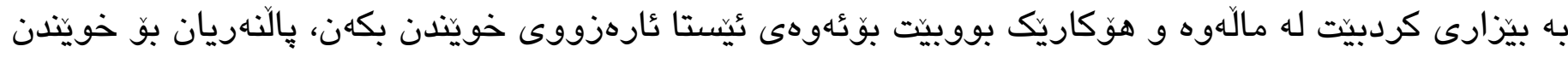

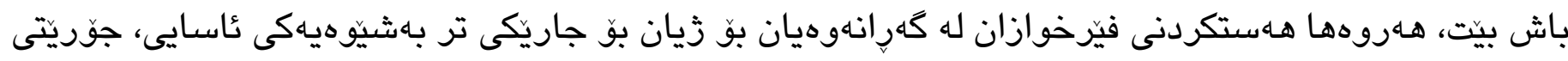

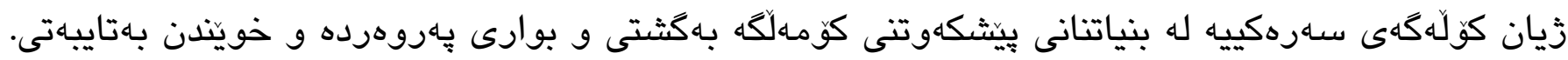

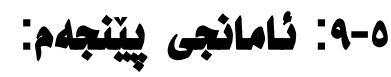

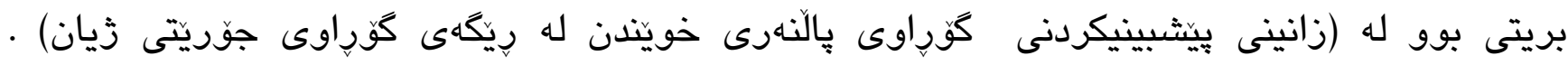

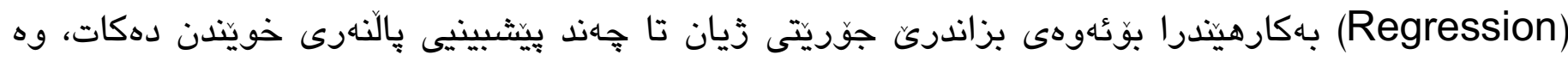
نموونهكه بيَكهاتبوو له (000) فيّرخواز.

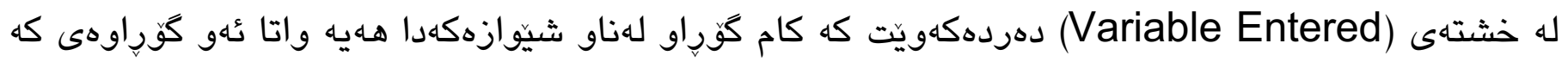

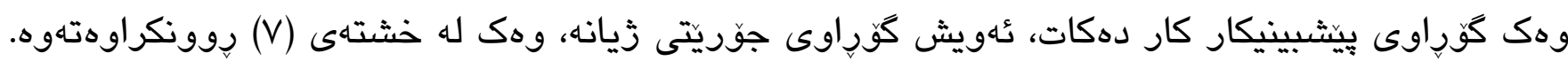

خشتهى (V)

كورياوى توماركراو (Variable Entered)

\begin{tabular}{|c|c|c|}
\hline 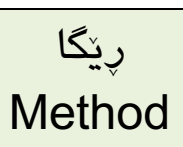 & $\begin{array}{c}\text { كزّراوى توماركراو } \\
\text { Variable Entered }\end{array}$ & شيَّاز \\
\hline Enter & جوّريتى زيان & 1 \\
\hline
\end{tabular}

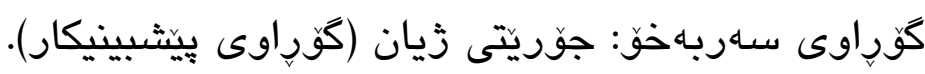

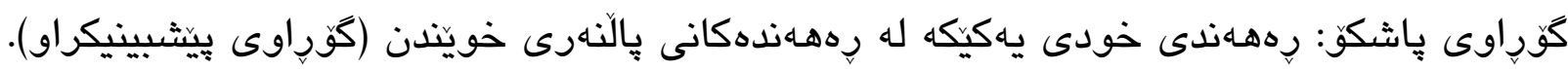

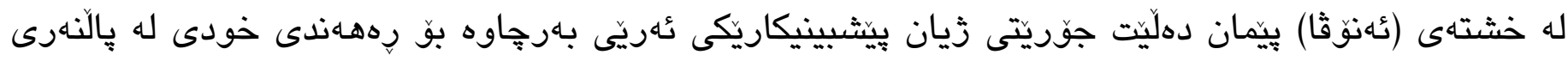

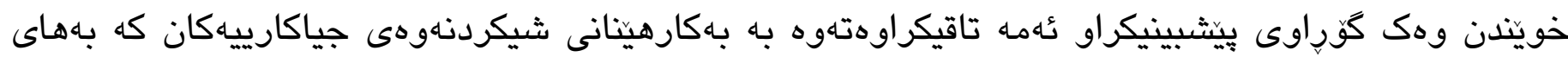

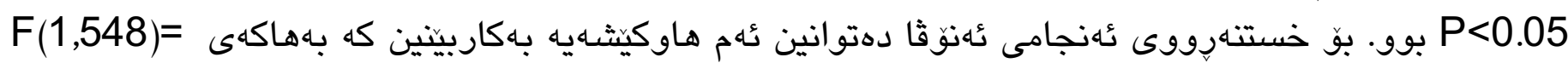

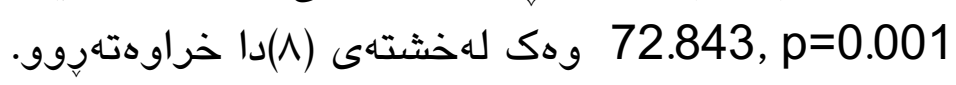




\section{خشتهى زماره (A)}

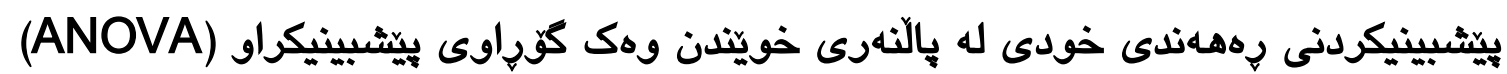

\begin{tabular}{|c|c|c|c|c|c|c|c|c|}
\hline $\begin{array}{c}\text { بالكهدارىى } \\
\text { Sig }\end{array}$ & $\begin{array}{l}\text { به هاى } \\
\text { (F) }\end{array}$ & $\begin{array}{c}\text { دوهاى } \\
\text { Mean } \\
\text { Square }\end{array}$ & 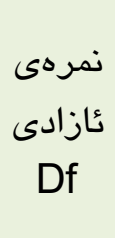 & $\begin{array}{c}\text { كؤى دوجان } \\
\text { Sum of } \\
\text { Squares }\end{array}$ & شodel & كَيَّبينيكراوى & كيّنبينيكار & $\dot{j}$ \\
\hline 0.001 & 72.843 & 723.066 & 1 & 723.066 & Regression & \multirow{3}{*}{ خِ خِدهـندى له } & \multirow{3}{*}{ جوّيان } & \multirow{3}{*}{1} \\
\hline & & 9.926 & 548 & 5439.627 & Residual & & & \\
\hline & & & 549 & 6162.693 & Total & & & \\
\hline
\end{tabular}

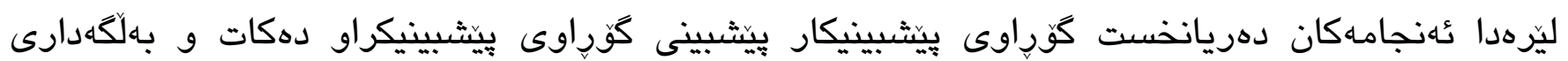
ئامارييه.

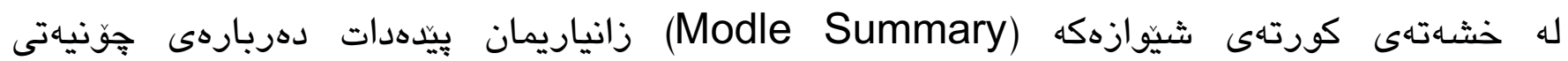

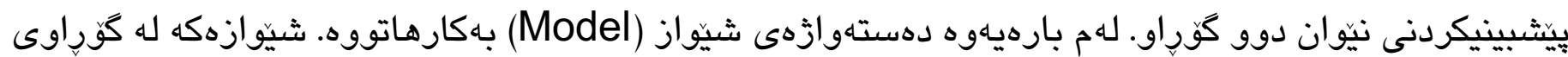

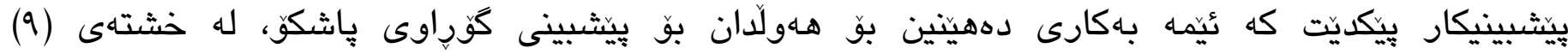

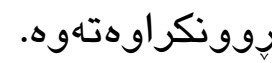

خشتهى (9) (9)

(Model Summary) كورتهى شيّيوازهك (9)

\begin{tabular}{|c|c|c|c|c|c|}
\hline $\begin{array}{l}\text { هـلّى خهملاندن } \\
\text { Std. Error of } \\
\text { the Estimate }\end{array}$ & 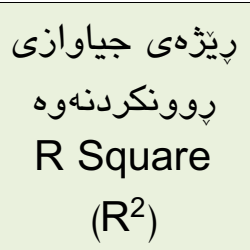 & 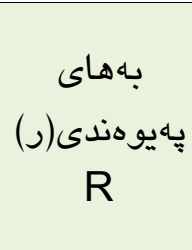 & يَّيثبينيكراوى & 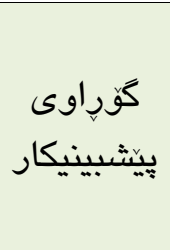 & شئيّاز \\
\hline 3.150 & 0.117 & $0.343^{a}$ & 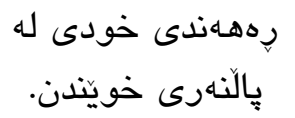 & جَّريتى & 1 \\
\hline
\end{tabular}

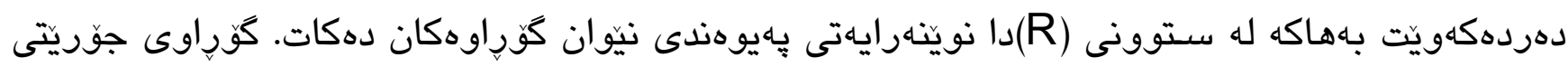

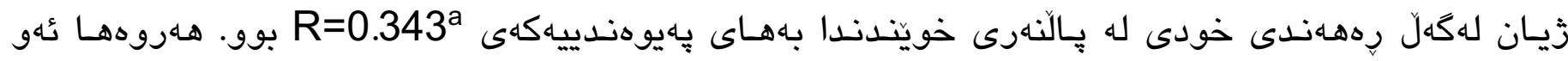

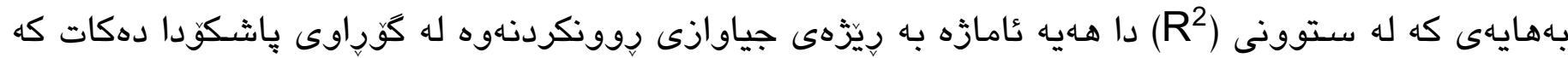

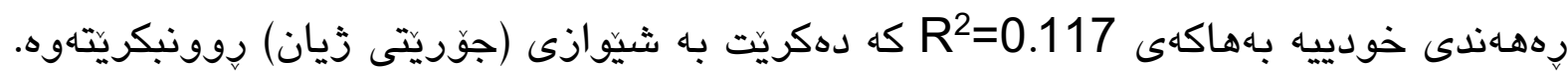

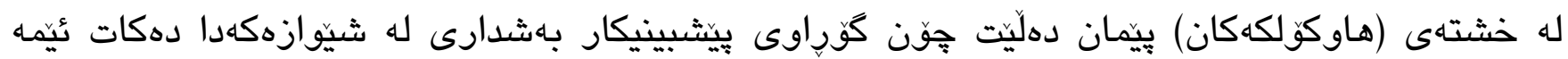

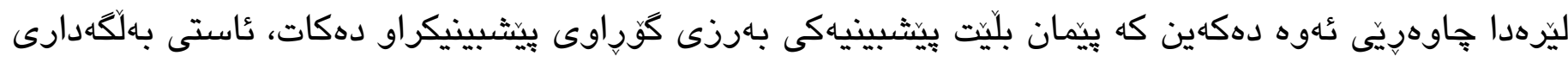

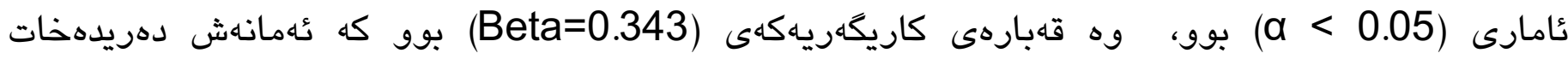

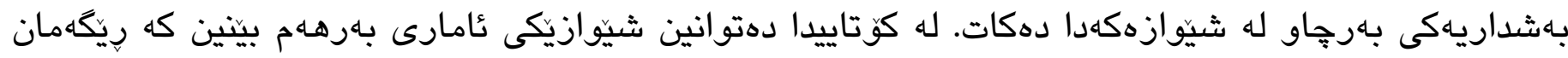

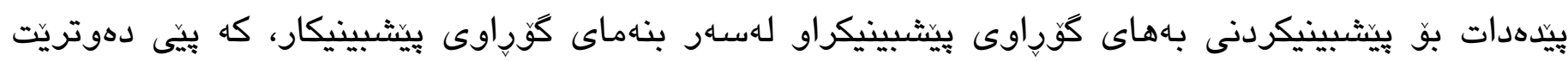

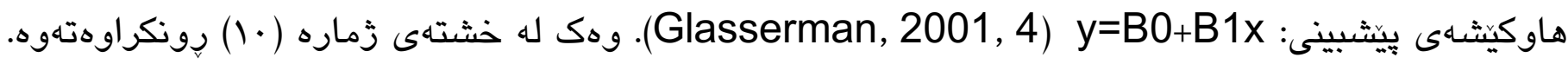




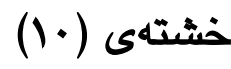

هاوكولكهان ( Coefficients )

\begin{tabular}{|c|c|c|c|c|c|c|}
\hline \multirow[t]{2}{*}{ 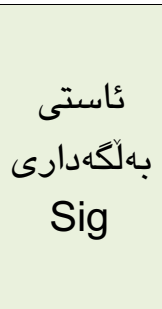 } & \multirow[t]{2}{*}{ بهاى (T) } & \multicolumn{2}{|c|}{$\begin{array}{c}\text { ستانداركراوهكان } 1 \text { هاوكة } \\
\text { Standardized } \\
\text { Coefficients }\end{array}$} & \multirow[t]{2}{*}{ 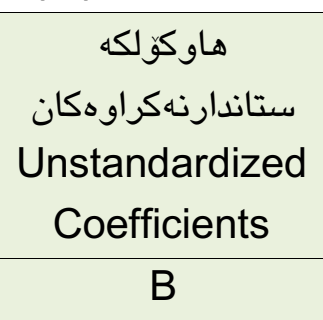 } & \multirow{2}{*}{\multicolumn{2}{|c|}{ شيَّاز }} \\
\hline & & Beta & Std. Error & & & \\
\hline 0.001 & 5.387 & & 1.152 & 6.208 & جيكير(Constant) & \\
\hline$\cdot .001$ & 8.535 & $\cdot .343$ & $\cdot .006$ & $\cdot .050$ & جوريتتى زيان & \\
\hline
\end{tabular}

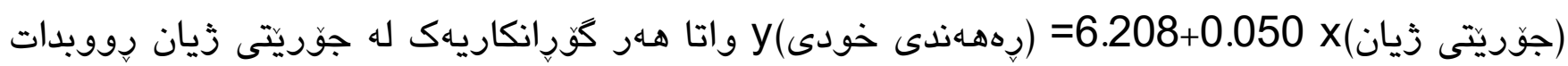

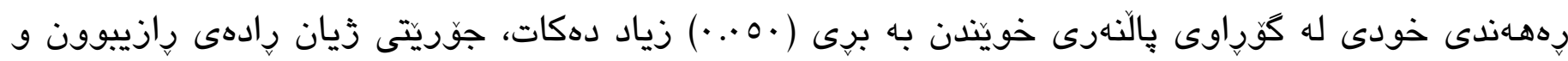

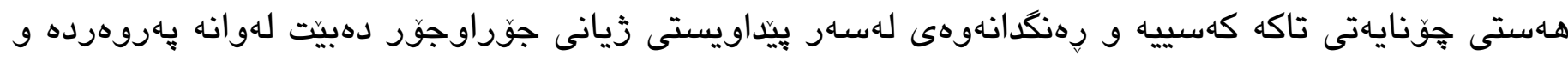

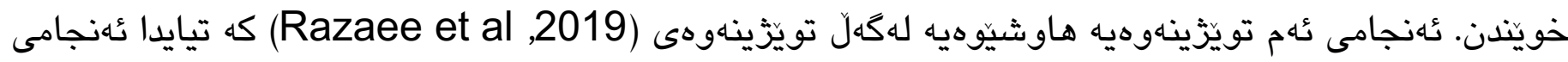

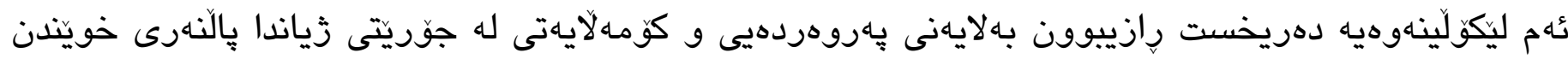

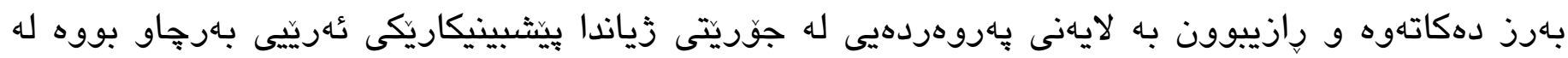

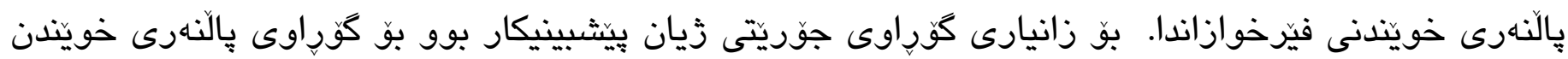

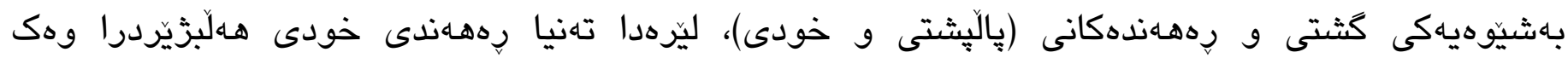

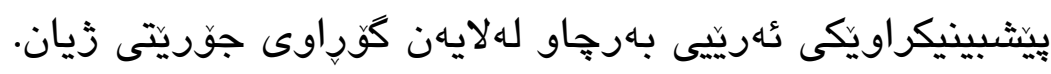

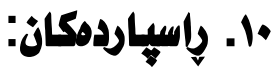

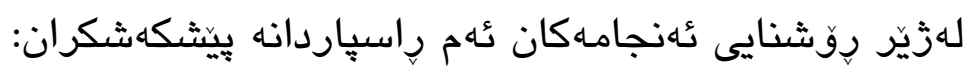

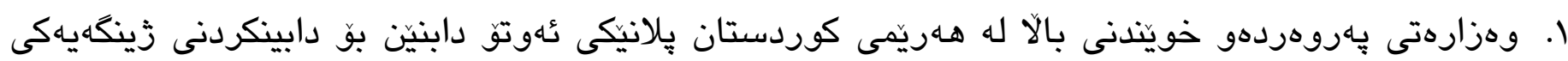

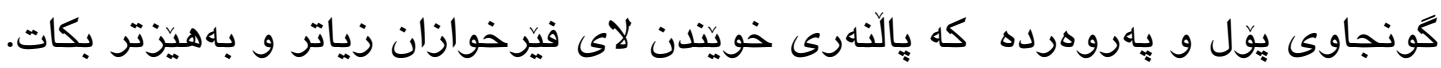

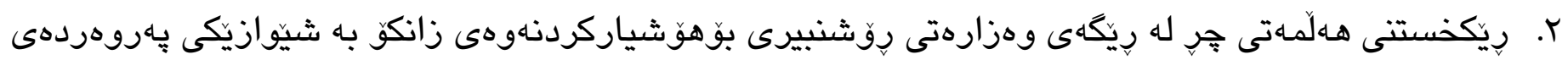

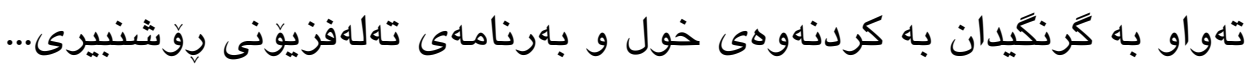

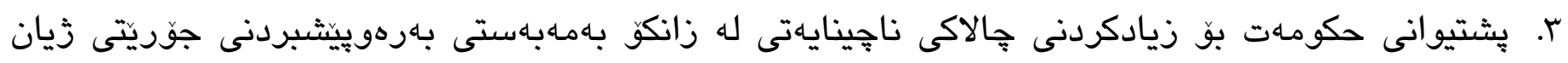
لهنيّوان فيّرخوازان و ماموّستايان.

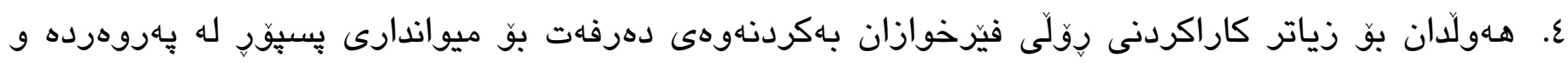

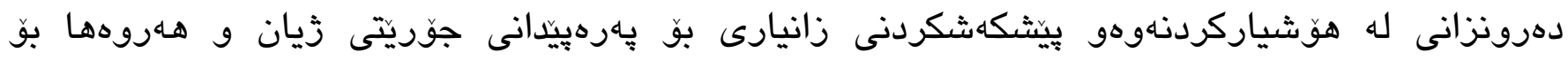

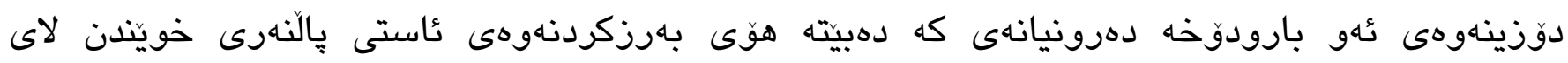
فيَرخوازان. 


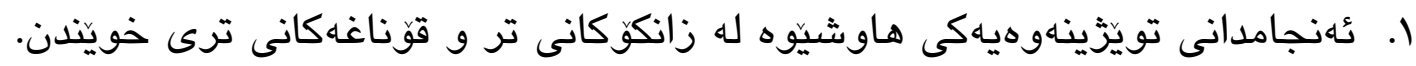

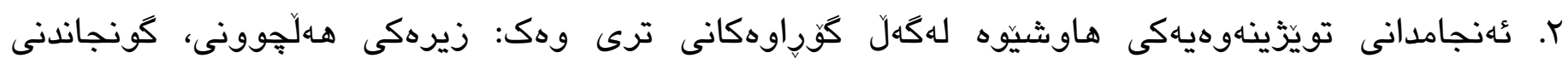

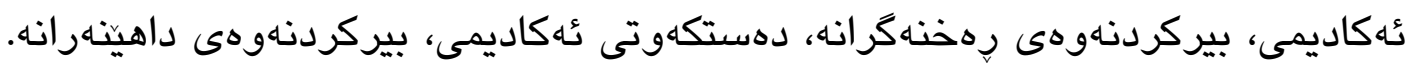

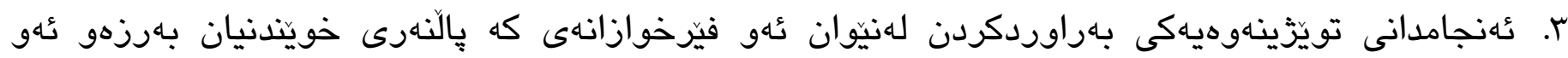

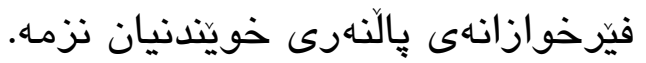

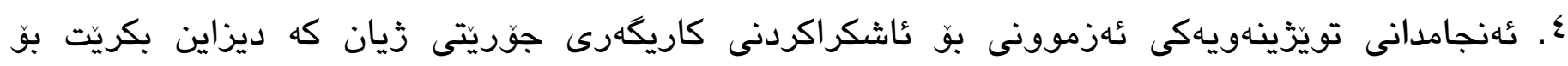

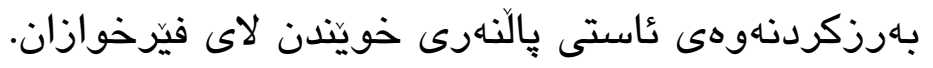




\title{
Quality of life and its Relationship to Studying Motivation among Koya University Students
}

\section{Paiz Khalid Sabir}

Education and psychology Department, Faculty of Education, Koya University, Koya, Kurdistan Region, Iraq.

E-mail: paiz.khalid@koyauniversity.org

\section{Khalid Ismail Mustafa}

Education and psychology Department, Faculty of Education, Koya University, Koya, Kurdistan Region, Iraq.

E-mail: khalid.ismail@koyauniversity.org

\begin{abstract}
:
The purpose of this study is to find out the level of the quality of life according to its dimensions, and constructing the measurement of the studying motivation, to display the levels of studying motivation from the part of the university students. The paper tries to find the relationship between quality of life and studying motivation and figure out the presupposition of studying motivation through the quality of life. The relevant descriptive method was adopted in the study. The population of the study is made up of (3466) students. The sample of the study for the first setting was of (465) students, the second setting was of $(00$.$) male$ and female students, they are selected in a random clustered way. For collecting information, the researchers used two measures: the quality of life is taken and the measures of studying motivation is constructed, the results turned out that the quality of life of students is at an acceptable level. For constructing the measures of studying motivation, the analysis of principles of used dimensions, divided the measurement into three dimensions, it turned out that the studying motivation is at an acceptable level. There are statistical positive evidences for the relation between quality of life and studying motivation. It turned out that quality of life presupposes a remarkable self-dimension in studying motivation. Finally, the researcher in the light of the results, offered some recommendations and suggestions.
\end{abstract}

Key words: Quality, Life, Quality of Life, Motivation, Studying Motivation. 


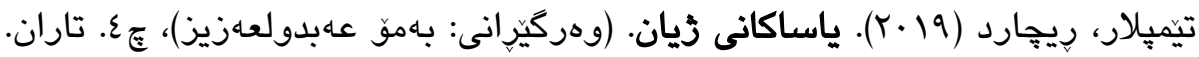

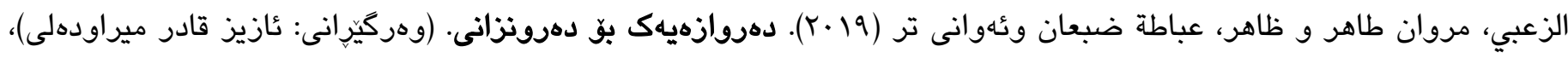

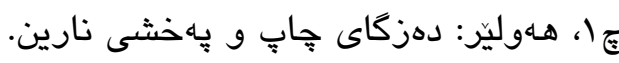

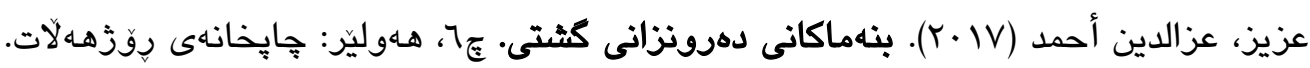

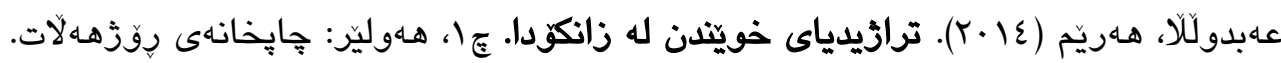

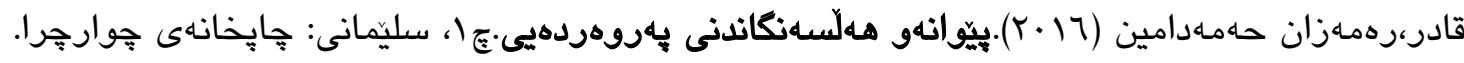

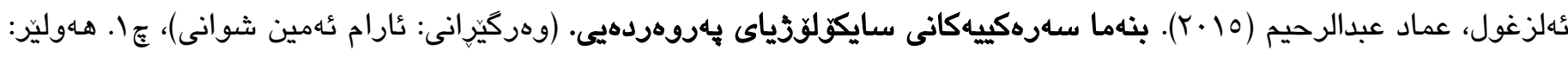

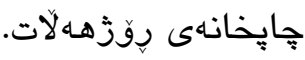

ابوزيد، عبدالباقي عبدالمنعم و ابراهيم،محمد عبدالرزاق (Y. . . . مهارات البحث التربوي. طا، الأردن: دار الفكر.

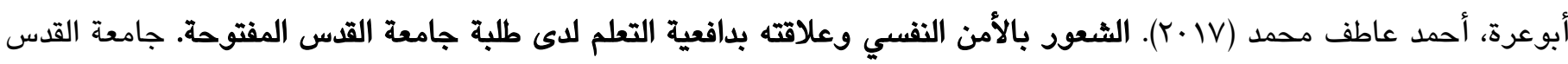

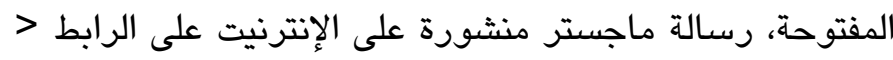
- V > https://www.qou.edu/ar/sciResearch/pdf/master/irshad/ahmadAtefAbuErra.pdf .Y.Y. أمال، بن يوسف (1 · ·r). العلاقة بين استراتيجيات التعلم والدافعية للتعلم وأثرهما على التحصيل الدراسي. جامعة الجزائر، كلية

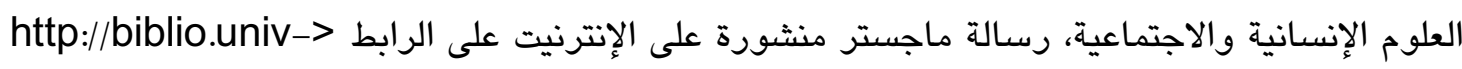
alger.dz/xtf/data/pdf/1110/BENYOUCEF_AMEL.pdf أمال، بوعيشة (ع إ).جودة الحياة و علاقتها بالهوية النفسية لدى ضحايا الإرهاب بالجزائر - دراسة ميدانية بيلدية براقي دائرة

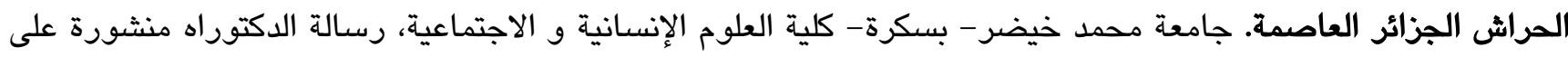

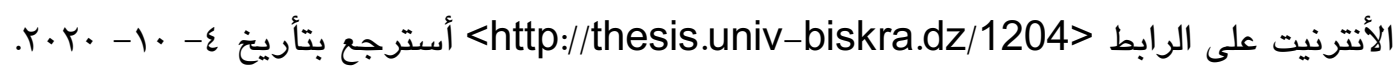

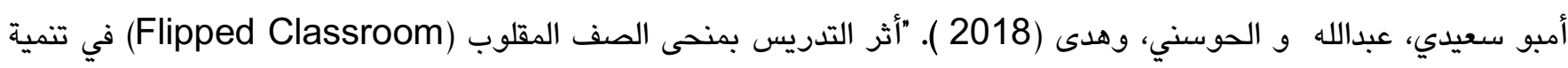
الدافعية لتعلم العلوم والتحصيل الدراسي لدى طالبات الصف التاسع الأساسي"، مجلة جامعة النجاح للأبحاث - العلوم الإنسانية ،

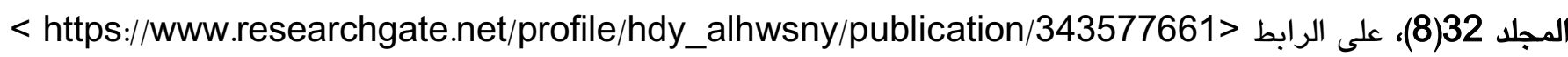

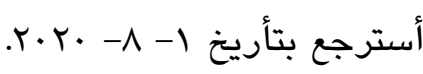

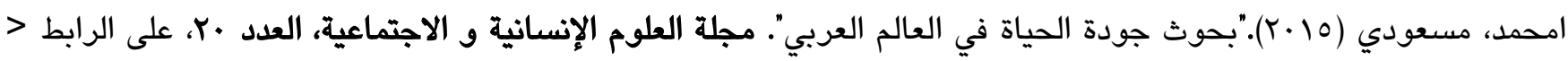

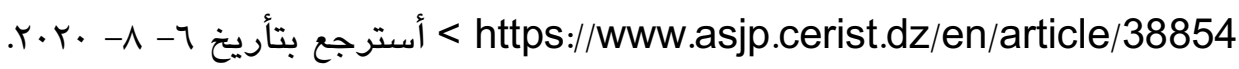
بكر، جوان إسماعيل (rا • ب). جودة الحياة وعلاقتها بالإنتماء والقبول الاجتماعيين. طا، عمان: دار ومكتبة الحامد للنشر والتوزيع.

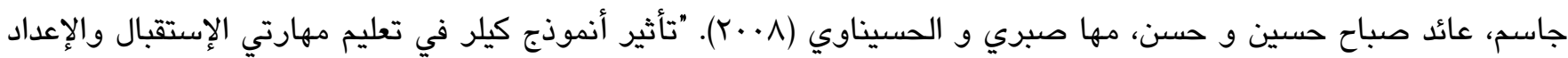

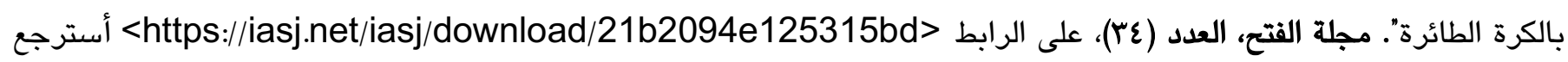

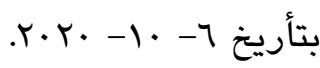

جمال، ميسون (19 • (1). "أثر استخدام وسائل التواصل الاجتماعي في دافعية التعلم واتخاذ القرار لدى طلبة الثانوية في مدينة

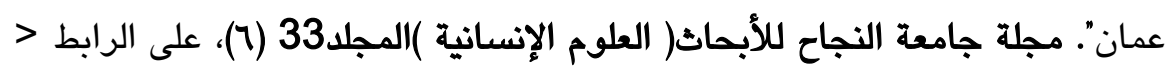
Thtps://journals.najah.edu/media/journals/full_texts/1_0y3WqnA.pdf 
الجوهر، زواقي و كهينة، بركان (19 (Y). التوافق النفسي وعلاقته بالدافعية للتعلم لدى تلاميذ السنة أولى ثانوي. جامعة أكلى محند

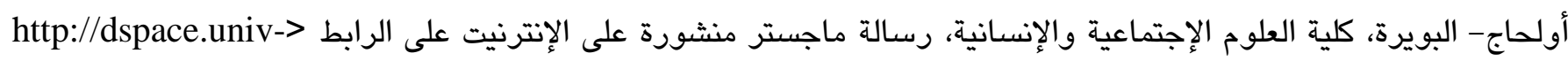
bouira.dz:8080/jspui/bitstream/123456789/5788/1/\%D8\%B2\%D9\%88\%D8\%A7\%D9\%82\%D9\%8A\%20\%

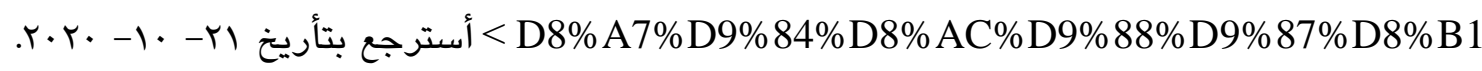

حلمي، رنيا وجيه (^1 •r)." مقرر إلكتروني لتنمية التحصيل المعرفي والدافعية للتعلم لدى الطالبات المعلمات بكلية التربية للطفولة

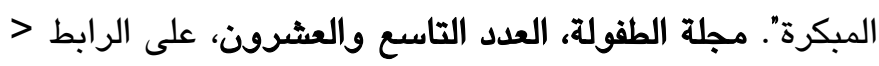
بأسترجع بتأريخ http://jchild.journals.ekb.eg/article_74146_ff2a32642bf5bb86e97d8210b88a785e.pdf $r \cdot r \cdot-1 t-r$ الخزاعلة، محمد سلمان فياض و الزبون، منصور حمدون و الخزاعلة، خالد عبدالله و الشويكي، عساف عبد ربة (11) (1). طرائق

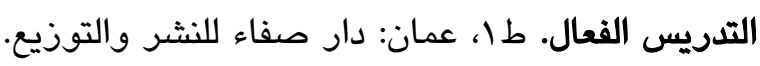

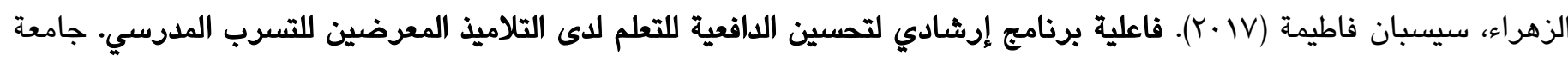

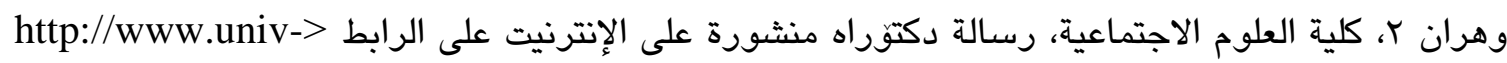
oran2.dz/images/these_memoires/FSS/Doctorat/TDSSA92/\%D8\%A7\%D9\%84\%D9\%88\%D8\%A7\%D8\%AC\%D9\%87\%D8\%A9\%20+\%20\%D8\%A7\%D9\%84\%D r.Y. -1 1 9\%85\%D9\%84\%D8\%AE\%D8\%B5.pdf سرحان ، سهيرزكي محمود (2015). الدافعية للتعلم والذكاء الانفعالي وعلاقتة بالتحصيل الدراسي لدي طلبة المرحلة الإعدادية

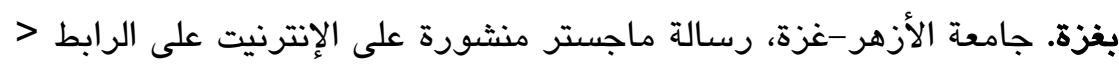

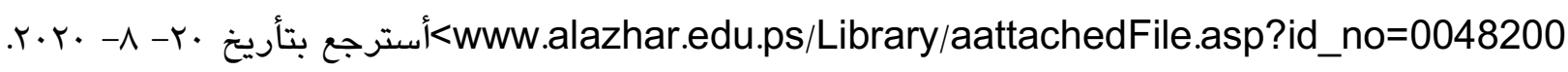

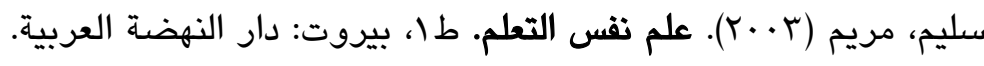

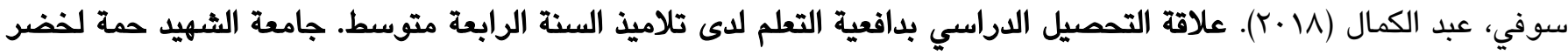

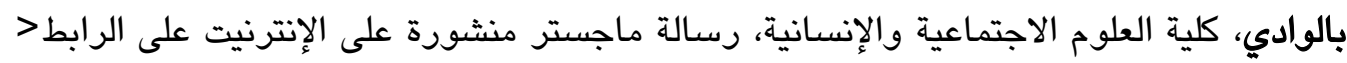
http://193.194.92.111/bitstream/123456789/1063/1/\%D8\%B9\%D9\%84\%D8\%A7\%D9\%82\%D8\%A9\%20\% D8\%A7\%D9\%84\%D8\%AA\%D8\%AD\%D8\%B5\%DB\%8C\%D9\%84\%20\%D8\%A7\%D9\%84\%D8\%AF\%D r.r. - 8\%B1\%D8

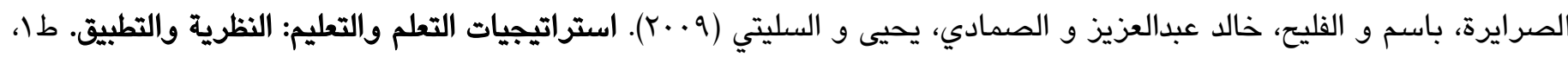

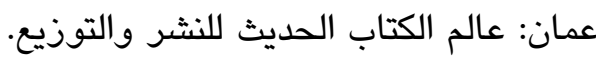

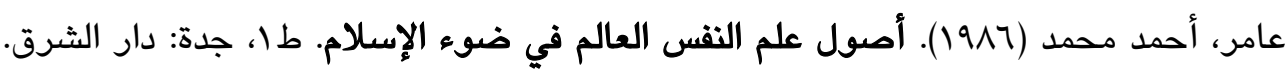

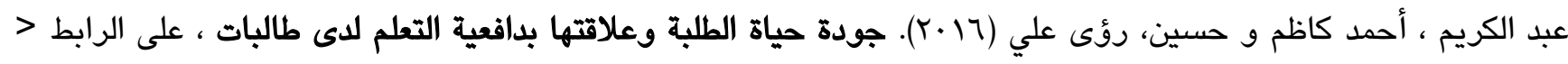

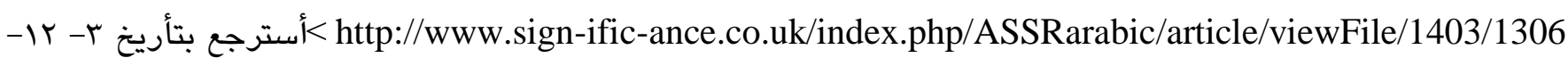
.Y.Y.

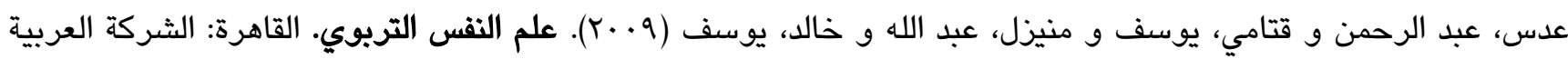
المتحدة للتسويق و التوريدات بالتعاون مع جامعة القدس المفتوحة.

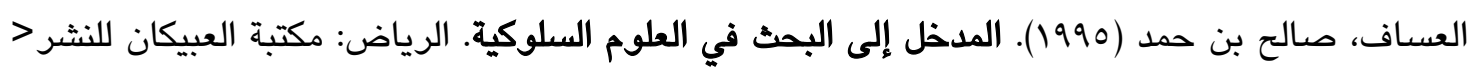

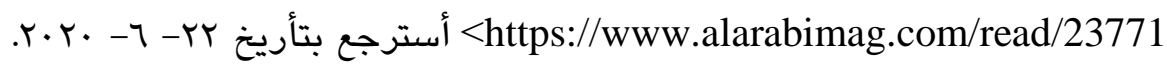

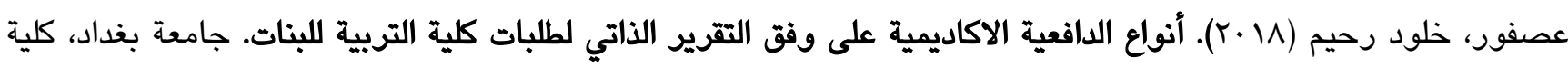

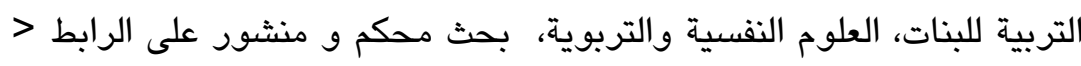

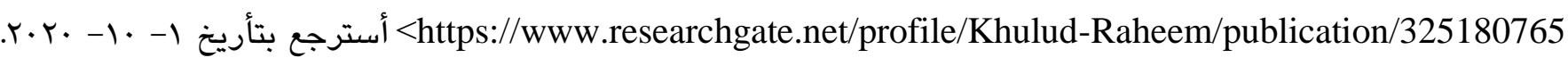




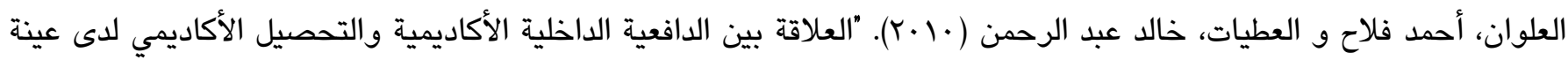
من طلبة الصف العاشر الأساسي في مدينة معان في الأردن". مجلة الجامعة الإسلامية (سلسلة الدراسات الإنسانية) المجلد الثامن عشر، العدد الثاني، على الرابط

أسترجع بتأريخ ץ-https://journals.iugaza.edu.ps/index.php/IUGJHR/article/download/861/804 على، محمد سيد (1) (Y). موسوعة مصطلحات التربوية. طا، عمان: دار المسيرة.

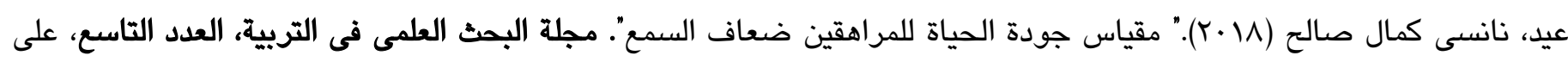

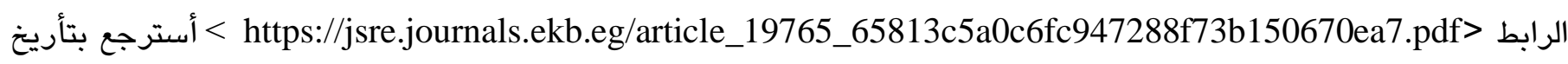
$. r \cdot Y \cdot-\Lambda-17$

الفتلاوي، فاطمة عبد الأمير و المياحي، إيثار عبد المحسن قاسم (YV) (Y. (Y). " قلق العنف وعلاقته بالدافعية للتعلم". مجلة كلية التربية

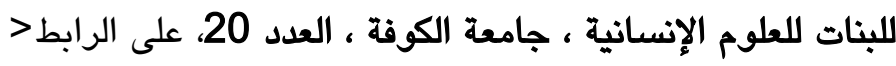

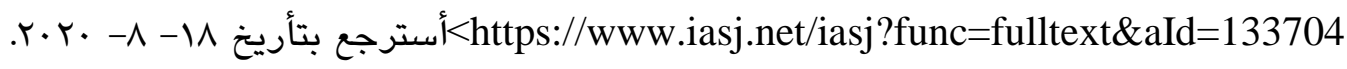

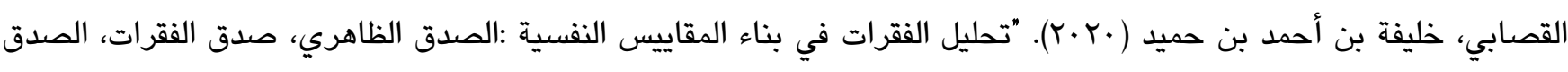

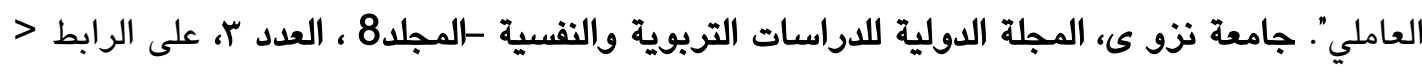
http://www.refaad.com/Files/EPSR/EPSR-8-3-1.pdf مصطفى، بعلي و يوسف، جغلولي (N (Y)."مستوى جودة الحياة لدى طالبات جامعة المسيلة دراسة ميدانية على عينة من طالبات قسم علم النفس بجامعة المسيلة. الجزائر". مجلة الجامع في الدراسات النفية والعلوم التربوية، العدد ^، على الرابط > > http://dspace.univmsila.dz:8080/xmlui/bitstream/handle/123456789/18345/\%D9\%85\%D8\%B3\%D8\%AA\%D9\%88\%D9\%89 \%20\%D8\%AC\%D9\%88\%D8\%AF\%D8\%A9\%20\%D8\%A7\%D9\%84\%D8\%AD\%D9\%8A\%D8\%A7\%D8\% .r.Y. -V - - أسترجع بتأريخ A9\%20\%D9\%84\%D8\%AF\%D9\%89\%20\%

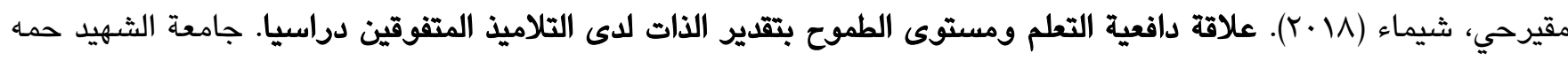

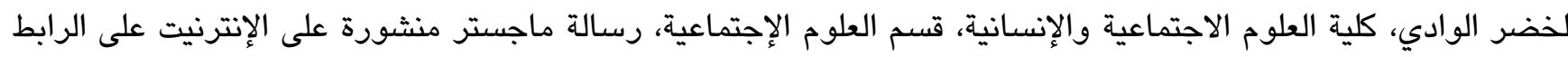
http://dspace.univ-> eloued.dz/xmlui/bitstream/handle/123456789/1070/\%d8\%b9\%d9\%84\%d8\%a7\%d9\%82\%d8\%a9\%20\%d8\%

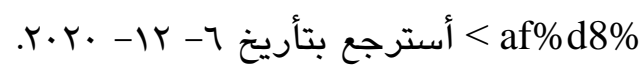
منسي، محمود عبدالحليم و كاظم، علي مهذي (2010). "تطوير و تقنين مقياس جودة الحياة لدى طلبة الجامعة في سلطنة عمان".

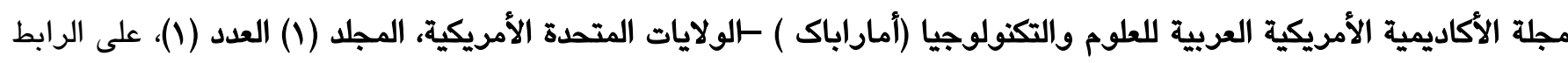
r.Y. - V - https://abhathna.com/files/maqa/1157.pdf> منسي، محمود عبدالحليم و كاظم، علي مهدي (2006). مقياس جودة الحياة لطلبة الجامعة،جامعة السلطان قابوس، كليةالتربية، بحث

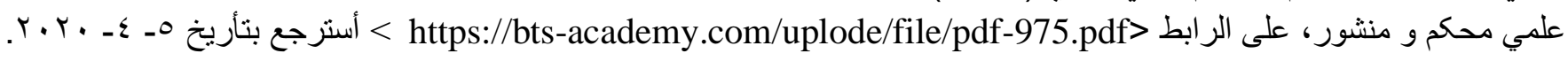

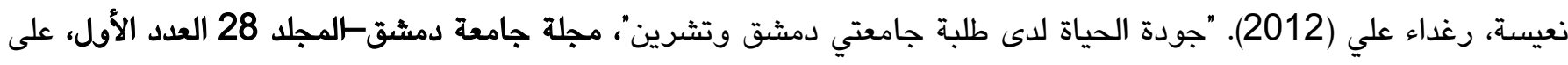

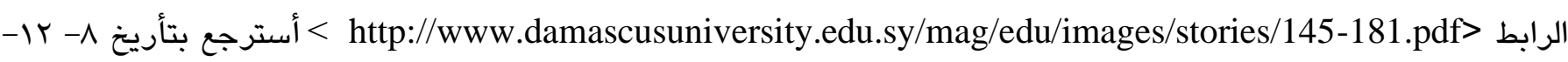
r.r.

نورس، بخوش و خرفية،حميداني (17 (r). جودة الحياة وعلاقتها بالصحة النفسية لدى طالبات جامعة زيان عاشور · جامعة زيان عاشور الجلفة، كلية العلوم الإنسانية و الاجتماعية، قسم العلوم الجتماعية، رسالة ماجستر منشورة على الإنترنيت على الرابط > http://dspace.univ-

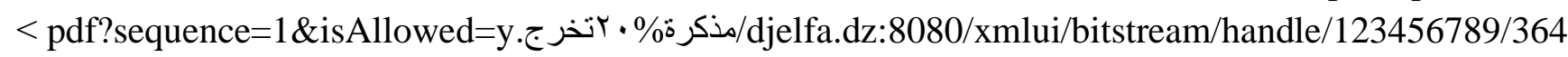
أسترجع بتأريخ 10- T. - و. 
Abdi, H., 2003. Factor Rotations in Factor Analyses. The University of Texas, Available through: < http://www.utd.edu/ herve/Abdi-rotations-pretty.pdf > [Accessed 12 January 2021].

Allen, M. \& Yen, W.M., 1979. Introduction to measurement theory. Available through: < https://pdfcoffee.com/allen-amp-yen-1979-introduction-to-measurement-theory-cap-7pdf-pdf-free.html> [Accessed 11 November 2020].

Andrasko, I., 2013. Quality of Life: An Introduction to the Concept. Was published within the ECOPproject, Available through: <

https://munispace.muni.cz/index.php/munispace/catalog/download/779/2495/405-1>[Accessed 18 September 2020].

Frith, C., (n.d). Motivation To Learn. Educational Communications and Technology University of Saskatchewan, Available through: < http://www.wachum.com/dewey/300/motivation1.pdf > [Accessed 3 November 2020].

Glasserman, P., 2001. Linear Regression. Culombia Business School, Available through: < https://www0.gsb.columbia.edu/faculty/pglasserman/B6014/Regression.pdf > [Accessed 3 March 2020]. Malik, S., 2014. "EFFECTIVENESS OF ARCS MODEL OF MOTIVATIONAL DESIGN TO OVERCOME NON COMPLETION RATE OF STUDENTS IN DISTANCE EDUCATION”. Journal of Distance Education-TOJDE, (e-journal) 15 (2), [online], Available through: < https://files.eric.ed.gov/fulltext/EJ1043079.pdf > [Accessed 27 March 2020].

Mustafa, K. I., Ismail, A. A. \& Abdullah, Z. D., 2019. "Quality of Life and Emotional Intelligence among University Lecturers”. 10th International Visible Conference on Educational Studies \& Applied Linguistics, Available through: <https://www.researchgate.net/profile/Zhwan-

Dalshad/publication/344418866_Quality_of_Life_and_Emotional_Intelligence_among_University_Lecturer s/links/5f73a600299bf1b53effd947/Quality-of-Life-and-Emotional-Intelligence-among-University-

Lecturers.pdf> [Accessed 3 September 2020].

Pedditzi, M. L. \& Spigno, M., 2012. “Motivation to learn: a research on university students". International Conference on Education and Educational Psychology, Procedia - Social and Behavioral Sciences, Vol. 69 Pages 1198 - 1207, [online] Available at: < https://www.researchgate.net/publication/271880760_Motivation_to_Learn_A_Research_on_University_St udents > [Accessed 1 March 2020].

Rebekic, A.,Loncaric, Z., Petrovic, S.\& Maric,S., 2015. "PEARSONS OR SPEARMANS CORRELATION COEFFICIENT- WHICH ONE TO USE?. Poljoprivreda 21 (2)47-54, Available through: < https://hrcak.srce.hr/file/221611> [Accessed 22 November 2020].

Rezaee R., Pabarja E.,\& Mosalanejad L., 2019. "Students' Academic Quality of Life and Learning Motivation in Iran Medical University - pilot from south Iran”. P J M H S Vol. 13, NO. 2, Available through: < https://www.researchgate.net/publication/336315668_Students'_Academic_Quality_of_Life_and_Learning_ Motivation_in_Iran_Medical_University_-pilot_from_south_Iran > [Accessed 6 November 2020]. Rudhumbu N., 2014. "MOTIVATIONAL STRATEGIES IN THE TEACHING OF PRIMARY SCHOOL MATHEMATICS IN ZIMBABWE”. International Journal of Education Learning and Development UK, (ejournal) 2(.2), pp. 76-103, Available through: < http://www.eajournals.org/wp-

content/uploads/Motivational-Strategies-in-the-Teaching-of-Primary-School-Mathematics-in-Zimbabwe.pdf $>$ [Accessed 2 October 2020].

Theofilou, P., 2013.” Quality of Life: Definition and Measurement”. Europe's Journal of Psychology, (ejournal) 9(1), 150-162, Available through< 
https://citeseerx.ist.psu.edu/viewdoc/download?doi=10.1.1.299.4629\&rep=rep1\&type=pdf $>$ [Accessed 15 March 2020].

Usher, Alexandra; Kober, Nancy 2012. "Student Motivation: An Overlooked Piece of School Reform".

Center on Education Policy, Available through: < http://files.eric.ed.gov/fulltext/ED532666.pdf $>$ [Accessed 11 October 2020].

VanVoorhis, C. R. W. \& Morgan, B. L. 2007. "Understanding Power and Rules of Thumb for Determining Sample Sizes”. Psi Chi Journal, (e-journal)3(2), p. 43-50, Available through: <

https://www.researchgate.net/publication/49619425_Understanding_Power_and_Rules_of_Thumb_for_Det ermining_Sample_Size >[Accessed 28 November 2020].

Veenhoven, R., 2006. THE FOUR QUALITIES OF LIFE. Published in: Mark McGillivray \& Mathew Clark (Eds.), United Nations University Press, Tokyo0-NewYork-Paris Available through: < https://www.researchgate.net/publication/23545417_The_Four_Qualities_of_Life > [Accessed 7 March 2020].

Weiten, W., 2007. Psychogy Themes and Variations. $7^{\text {th }}$ ed, United States of America. 